\title{
Role of PI3K/AKT pathway in cancer: the framework of malignant behavior
}

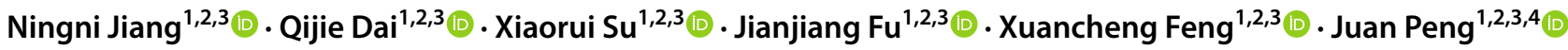

Received: 15 January 2020 / Accepted: 3 April 2020 / Published online: 24 April 2020

(c) The Author(s) 2020

\begin{abstract}
Given that the PI3K/AKT pathway has manifested its compelling influence on multiple cellular process, we further review the roles of hyperactivation of PI3K/AKT pathway in various human cancers. We state the abnormalities of PI3K/AKT pathway in different cancers, which are closely related with tumorigenesis, proliferation, growth, apoptosis, invasion, metastasis, epithelial-mesenchymal transition, stem-like phenotype, immune microenvironment and drug resistance of cancer cells. In addition, we investigated the current clinical trials of inhibitors against PI3K/AKT pathway in cancers and found that the clinical efficacy of these inhibitors as monotherapy has so far been limited despite of the promising preclinical activity, which means combinations of targeted therapy may achieve better efficacies in cancers. In short, we hope to feature PI3K/ AKT pathway in cancers to the clinic and bring the new promising to patients for targeted therapies.
\end{abstract}

Keywords PI3K $\cdot$ AKT $\cdot$ PTEN $\cdot$ Cancer $\cdot$ Targeted therapy

\section{Abbreviations}

ABC Activated B cell-like

AI Aromatase inhibitor

ALL Acute lymphoblastic leukemia

AML Acute myeloid leukemia

AKT Protein kinase B

ATC Anaplastic thyroid cancer

ATL Adult T cell leukemia/lymphoma

AYA Adolescent and young adult

BC Breast cancer

BCBM Breast cancer brain metastases

Ningni Jiang, Qijie Dai, and Xiaorui Su have contributed equally to this work.

Xuancheng Feng

2816924339@qq.com; xuanchengfeng@outlook.com

Juan Peng

pengjuan1979@yahoo.com; pengjuan1979@gzhmu.edu.cn; jupeng@wakehealth.edu

Ningni Jiang

649144805@qq.com

Qijie Dai

13709628221@163.com

Xiaorui Su

2432754368@qq.com

Jianjiang Fu

2042632928@qq.com

$\begin{array}{ll}\text { BCL } & \text { B-cell lymphoma } \\ \text { BTKi } & \text { BTK inhibitors } \\ \text { ccfDNA } & \begin{array}{l}\text { Circulating cell-free DNA } \\ \text { CHL }\end{array} \\ \text { Classical Hodgkin lymphoma } \\ \text { CLL/SLL } & \begin{array}{l}\text { Chronic lymphocytic leukemia or small lym- } \\ \text { phocytic lymphoma }\end{array} \\ \text { CRC } & \text { Colorectal carcinoma } \\ \text { CRPC } & \text { Castration resistant prostate cancer } \\ \text { CSC } & \text { Cancer stem cell } \\ \text { EBV } & \text { Epstein-Barr virus } \\ \text { EC } & \text { Endometrial cancer } \\ \text { EEC } & \text { Endometrioid type of EC } \\ \text { EMT } & \text { Epithelial-mesenchymal transition }\end{array}$

1 Department of Pathology, The Third Affiliated Hospital of Guangzhou Medical University, 63 Duobao Road, Guangzhou 510150, China

2 The Third Clinical School of Guangzhou Medical University, Guangzhou 510150, China

3 Key Laboratory of Reproduction and Genetics of Guangdong Higher Education Institutes, Guangzhou 510150, China

4 Department of Microbiology and Immunology, Wake Forest School of Medicine, Winston-Salem, NC 27157, USA 


$\begin{array}{llll}\text { EOC } & \text { Epithelial ovarian cancers } & \text { PNETs } & \text { Pancreatic neuroendocrine neoplasms } \\ \text { ER } & \text { Estrogen } & \text { PO } & \text { Pharmacokinetics of oral } \\ \text { ESCA } & \text { Esophageal carcinoma } & \text { PTC } & \text { Papillary thyroid cancer } \\ \text { ESCC } & \text { Esophageal squamous cell carcinoma } & \text { PTCL } & \text { Peripheral T-cell lymphoma } \\ \text { EWS } & \text { Ewing's sarcoma } & \text { RCC } & \text { Renal cell cancer } \\ \text { FL } & \text { Follicular lymphoma } & \text { RP2D } & \text { Recommended phase 2 dose } \\ \text { FTC } & \text { Fallopian tube carcinoma } & \text { SCCHN } & \text { Squamous cell carcinoma of the head and } \\ \text { GBM } & \text { Glioblastoma multiforme } & & \text { neck } \\ \text { GC } & \text { Gastric cancer } & \text { SCLC } & \text { Small cell lung cancer } \\ \text { GCB cells } & \text { Germinal center B-cells } & \text { SE } & \text { Side effects } \\ \text { GCO } & \text { Global Cancer Observatory } & \text { SEC } & \text { Serous type of EC } \\ \text { GIST } & \text { Gastrointestinal stromal tumor } & \text { TC } & \text { Thyroid cancers } \\ \text { HCC } & \text { Hepatocellular carcinoma } & \text { TCL } & \text { T-cell lymphoma } \\ \text { HGOSC } & \text { High-grade OSC } & \text { TME } & \text { Tumor microenvironment } \\ \text { HL } & \text { Hodgkin's lymphoma } & \text { TNBC } & \text { Triple negative breast cancer } \\ \text { HNSCC } & \text { Head-and-neck squamous cell carcinoma } & \text { UM } & \text { Uveal melanoma } \\ \text { HR } & \text { Hormone receptor } & \text { XRT } & \text { Radiation therapy }\end{array}$

HRS cells Hodgkin- and Reed-Sternberg cells

HSCT Hematopoietic stem cell transplant

iB-NHL Indolent B cell non-Hodgkin's lymphoma

iNHL Indolent non-Hodgkin's lymphoma

IS Isoform-selective

IV Intravenous

LPL Lymphoplasmacytic lymphoma

MBC Metastatic breast cancer

MBM Medulloblastoma

mTOR Mammalian target of rapamycin

MCL Mantle cell lymphoma

MM Multiple myeloma

MRD Maximum recommended dose

MTD Maximum tolerated dose

mTORi Rapamycin inhibitor

MZL Marginal zone lymphoma

NHL Non-Hodgkin's lymphoma

NK/TCL NK/T cell lymphomas

NLPHL Nodular lymphocyte-predominant Hodgkin lymphoma

NSCLC Non-small cell lung cancer

OC Ovarian cancer

ORR Objective response rate

OS Osteosarcoma

OSC Ovarian serous cystadenocarcinoma

PBR Placebo in combination with bendamustine and rituximab

PC Pancreatic cancer

$\mathrm{PCa} \quad$ Prostate cancer

PCNSL Primary central nervous system lymphoma

PD Pharmacodynamics

PDAC Pancreatic ductal adenocarcinoma

PDTC Poorly differentiated thyroid cancer

PFS Progression-free survival

PI3K Phosphatidylinositol 3-kinase

PK Pharmacokinetics

\section{Background}

Cancer is considered as the major cause of mortality in the worldwide. According to the global cancer statistics of the Global Cancer Observatory (GCO), there will be 18.1 million new cases and 9.6 million cancer deaths worldwide in 2018 (World Health Organization. Cancer. 2018; https://gco. iarc.fr/). The top 5 most prevalent cancers in the world are lung cancer (LC), breast cancer (BC), prostate cancer (PCa), colon cancer and gastric cancer (GC, Table 1). In China, LC and liver cancer were two of the top five causes of death leading to years of life lost (YLLs) in 2017 [1]. Environmental and genetic risk factors have been recognized as the two major risk factors resulting in various tumorigenesis and cancer progression. Recent decades have witnessed the molecular understanding of the mechanisms of numerous genetic factors in human cancer, such as phosphatidylinositol 3-kinase/protein kinase B (PI3K/AKT), P53, NF-kB, STAT3, COX-2 and c-Myc. Apparently, PI3K/AKT pathway has gradually gotten a major focus of attention as it plays a crucial role in regulating diverse cellular functions, including metabolism, growth, proliferation, survival, transcription and protein synthesis.

The PI3Ks are a family of heterodimeric lipid kinases, which are grouped into class I, II, and III isoforms. Class IA subgroup of PI3Ks activated by receptor tyrosine kinases consist of a p110 catalytic subunit (p110 $\alpha, P I K 3 C A ; \mathrm{p} 110 \beta$, $P I K 3 C B ; \mathrm{p} 110 \delta, P I K 3 C D)$ and one of five p85-like regulatory subunits (p85 $\alpha, \mathrm{p} 55 \alpha, \mathrm{p} 50 \alpha$, PIK3R1; p85 $\beta$, PIK3R2; p55 $\gamma, P I K 3 R 3)$. Class IB subgroup of PI3Ks activated by $\mathrm{G}$ protein-coupled receptors consist of the catalytic

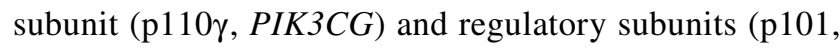
PIK3R5; p87, PIK3R6). Class II PI3Ks comprises PI3K$\mathrm{C} 2 \alpha(P I K 3 C 2 A), \beta(P I K 3 C 2 B)$ and $\gamma(P I K 3 C 2 G)$. And the 


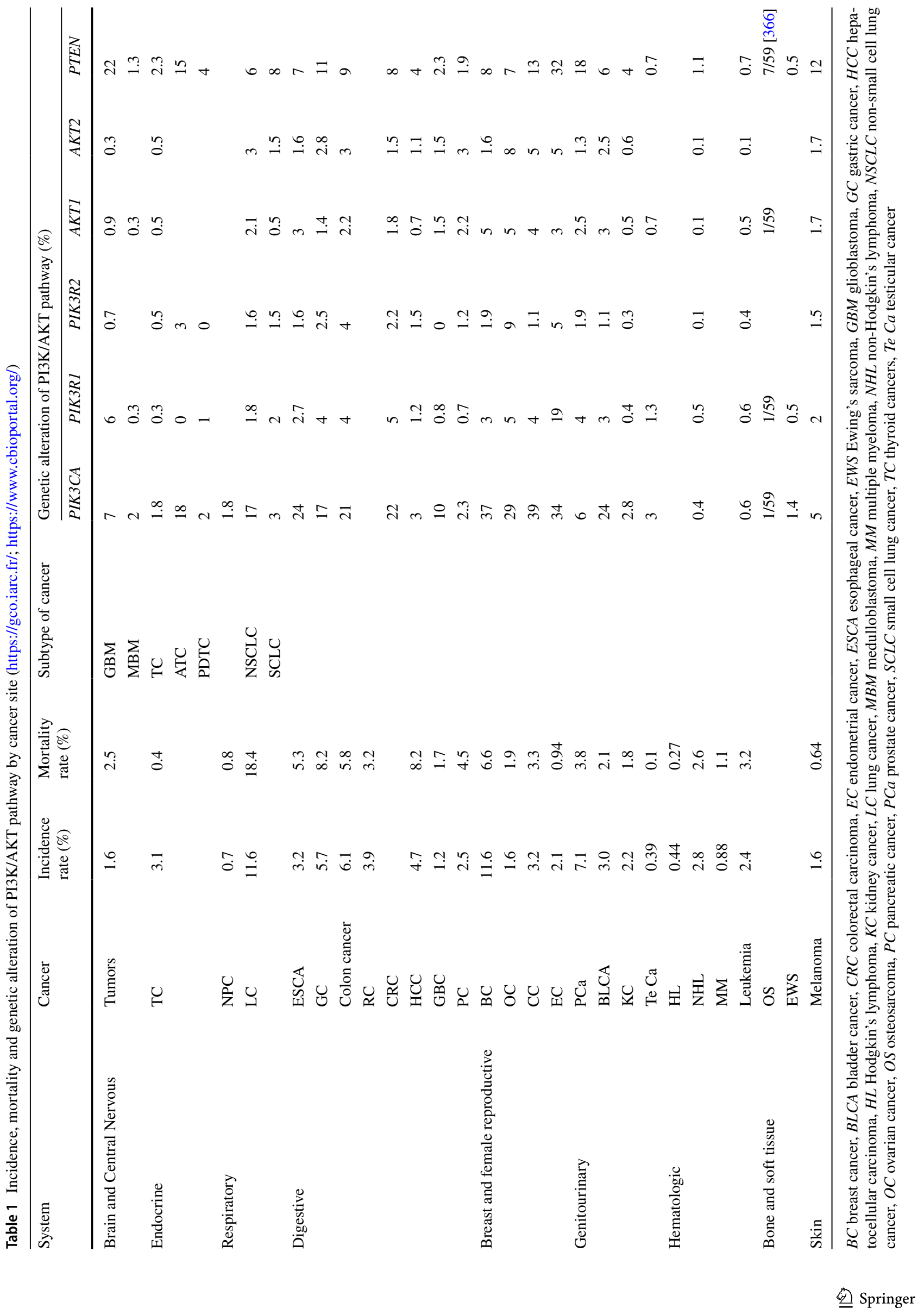


single class III PI3K is hVPS34 (PIK3C3). When PI3K is activated by a variety of upstream cell-surface receptors, including growth factor, antigen, costimulatory, cytokine, chemokine, and Toll-like receptors (TLRs), class I PI3Ks catalyzes the conversion of phosphatidylinositol 4,5-bisphosphate $\left(\mathrm{PI}(4,5) \mathrm{P}_{2}\right)$ with phosphorylation at the $\mathrm{D} 3$ position of the inositol ring to the second messenger phosphatidylinositol 3,4,5-triphosphate ( $\mathrm{PIP}_{3}$ ). Two $\mathrm{PIP}_{3}$-binding Pleckstrin homology $(\mathrm{PH})$ domain-containing proteins linked to PI3K activity in all cells, including B cells, are the serine/ threonine kinases AKT and phosphoinositide-dependent kinase-1 (PDK-1) [2-5].

AKT is an evolutionarily conserved serine protein kinase from the protein kinase AGC subfamily, which is composed of three conservative structure domains, including $\mathrm{N}$-terminal PH domain, a short C-terminal tail containing a regulatory hydrophobic motif (HM) and a linker region with a central kinase catalytic domain [6]. AKT contains three highly conserved homologous subtypes, AKT1/PKB $\alpha$ (AKT1), AKT2/PKB $\beta$ (AKT2) and AKT3/PKB $\gamma(A K T 3)$. On the cell membrane, AKT is recruited via its $\mathrm{PH}$ domain ascribing to the accumulation of $\mathrm{PI}(3,4,5) \mathrm{P}_{3}$ and $\mathrm{PI}(3,4) \mathrm{P}_{2}$ (less extent), and plays a catalytic role by activating two regulatory sites, including a threonine phosphorylated by PDK1 at Thr308(AKT1), Thr309(AKT2), Thr305(AKT3) and a serine phosphorylated by the mammalian Target of Rapamycin (mTOR) Complex mTORC2 at Ser473(AKT1), Ser474(AKT2), Ser472(AKT3) respectively as well as specifically [7, 8]. Massive researches have shown that AKT regulates vital downstream effector molecules, such as FOXO, mTOR, GSK3b, and many other effectors via phosphorylation cascade reaction, which is modulated by lipid and protein phosphatases, to control cell growth, proliferation, survival, genome stability, glucose metabolism, and neovascularization [9-12]. However, the activities of these phosphatases are frequently lost or inactivated evidently in human cancer, followed by the result of AKT hyperactivation.

When talking about PI3K/AKT pathway, we have to mention phosphatase and tensin homolog deleted on chromosome 10 (PTEN), the primary negative regulator of the PI3K/AKT pathway. As a lipid phosphatase, PTEN directly suppresses the activation of PI3K/AKT pathway via converting the $\mathrm{PIP}_{3}$ generated by PI3K back to $\mathrm{PIP}_{2}$. The $\mathrm{p} 85 \alpha$ regulatory subunit has a dual effect on the $\mathrm{p} 110 \alpha$ catalytic subunit, since p $85 \alpha$ inhibits the activity of p110 $\alpha$ while it plays an important role in the stability of $\mathrm{p} 110 \alpha$. In addition, the $\mathrm{p} 85 \alpha$ regulatory subunit has been proven to directly bind PTEN and enhance its activity to promote the conversion of PIP3 to PIP 2 [13, 14]. Indeed, the abnormality of PTEN have been validated in diverse cancers, even directly related with carcinogenesis in some cancers.
Following the emerging alterations of PI3K/AKT pathway genes have been widely reported in cancers recently, the inhibitors of PI3K/AKT pathway have brought a new era for targeted therapy of cancer. Since the first approval of idelalisib (CAL-101) validated the druggability of the PI3K pathway, more and more PI3K inhibitors have been created. They are generally divided into pan-PI3K (targeting all four isoforms of class I PI3K), isoform-selective (targeting single isoform of class I PI3K) and dual inhibitors (highlighted by dual PI3K/mTOR inhibitors). Comparatively, the number of AKT inhibitors which have been explored in clinical trials is less than that of PI3K inhibitors. AKT inhibitors mainly include two separate classes: Allosteric inhibitors and ATPcompetitive inhibitors. The formers prevent localisation of AKT by PH domain to the plasma membrane, thereby blocking AKT phosphorylation and activation. The latters targeting the phosphorylated conformation of AKT include first generation and second generation inhibitors $[15,16]$. These PI3K/AKT inhibitors have shown their various aptitude for anticancer in preclinical experiments or clinical trials, even druggable value for the anticancer treatment.

In this review, we present the comprehensive work of PI3K/AKT pathway with a new perspective in various cancer sites, in which elevated PI3K/AKT pathway is considered as a hallmark. Firstly, we state the abnormalities of PI3K/AKT pathway and summarize the roles of PI3K/AKT in aberrant signaling cascades in human cancers. Furthermore, we list the involvement of the PI3K/AKT inhibitors in the clinical trials of targeted therapies in cancers. Meanwhile, we briefly provide preliminary findings in the context of resistance to targeted therapies. Finally, we discuss the confusion and the future of the PI3K/AKT pathway.

\section{Recent studies and results}

\section{Profiling the PI3K/AKT pathway in the brain and central nervous system tumors}

Considering that the incidence and mortality of the brain and central nervous system tumors is $1.6 \%$ and $2.5 \%$ respectively in the worldwide (https://gco.iarc.fr/, Table 1), particularly the most common primary malignant tumor, glioblastoma multiforme (GBM), contributes to the poor prognosis partly for its tolerance of radiation therapy, hyper-activation of PI3K/AKT pathway in GBM caused by the mutations of PIK3CA or PIK3RI (18.3\%) and other PI3K family genes $(6.8 \%)$ has urged researchers to seek novel targeted treatments to control the disease [17-19]. Moreover, knockdown of PIK3CA or PIK3R1 significantly inhibits cell viability, migration and invasion in GBM cells via hypo-activation of AKT and FAK [20]. In addition, overexpression of p110 is more frequently detected in a series of GBM cell lines 
than in the patient tumor samples. PIK3CB knockdown suppresses cell proliferation and induces caspase-dependent apoptosis in GBM in vitro and vivo instead of suppressing GBM cell migration [21-23]. Therefore, PI3K inhibitors have been seriously studied in GBM for decades and some have achieved significant success in treating GBM.

As a matter of fact that more than 50 PI3K inhibitors have been designed and produced for cancer treatment, but only a minority of them such as BKM120, XL147, XL765 and GDC-0084 have successfully entered into clinical trials for GBM treatment (https://clinicaltrials.gov, Table 2) [18]. Some p1 $10 \alpha$ isoform-selective inhibitors, such as A66 or PIK-75, could effectively suppress the GBM cell growth, survival and migration in vitro [24], while inhibition of $\mathrm{p} 110 \beta$ by TGX-221 only arrests cell migration, and inhibition of p1108 by IC 87114 or CAL-101 moderately blocks cell proliferation and migration [22, 25]. However, PI3K inhibitors including A66 and BEZ235 are observed to increase the expression of cancer stem cell (CSC) genes (SOX2, OCT4 and MSI1) in GBM CSC models, which exhibit therapy resistance [26].

By the way, although AKT isoforms are observed to play different roles in GBM, including AKT3 delays tumor progression [27], as a matter of fact, the AKT inhibitor perifosine is tolerable but ineffective as monotherapy for GBM [28]. AKT inhibitors remain elusive and bear the weight of further examination in treating GBM.

Notably, building on that $22 \%$ genetic alterations of PTEN was detected in GBM (https://www.cbioportal.org, Table 1), especially deep deletion, which caused the loss of function of PTEN tumor suppressor, PTEN was deeply involved in the pathological effects of PI3K/AKT pathway in GBM [29]. Meanwhile, genetic loss of PTEN is associated with each subtype of GBM [30].

Additionally, glucose regulated protein 78 (GRP78) interacts with $\alpha 2$-macroglobulin to activate AKT1 via PDK1, as well as mTOR to enhance cancer cell proliferation and radiotherapy resistance in GBM [31-33]. Anti-GRP 78 antibody can restore cancer cells to sensitivity to radiation therapy, which inhibits cell proliferation and enhances apoptosis, and has the advantage of targeting against cancer cells without affecting normal cells. Moreover, combination of anti-GRP 78 antibody and radiation therapy (XRT) shows better inhibitory effect on tumor [31].

Compared to GBM, the genetic alteration of PIK3CA (2\%) and PIK3RI (0.3\%) in medulloblastoma (MBM, Table 1), which is the most aggressive malignant brain tumor that highly occurs in children and survival rate can reach $70 \%$ after active treatment, are less frequently observed [34]. However, enhance phosphorylation of AKT via PI3K or mTOR to restrain GSK3 in MBM, which lead to SOX9 degradation is reduced due to the facts that FBW7 degrades SOX9 under the guidance of GSK3. The loss of
FBW7 function increases SOX9 protein levels, increasing the malignancy of cancer and resistance to cisplatin [35]. As a major oncoprotein inhibitor, once FBW7 is deleted or mutated, it can cause tumors to occur directly [36, 37]. So targeted inhibition of the PI3K pathway has a bright therapeutic potential in MBM. Moreover, experiments show that combination of PI3K inhibitor, mTOR inhibitor and cisplatin can achieve better therapeutic effect [35], and how well LY3023414 works in recurrent MBM is being tested in an ongoing clinical trial (NCT03213678, Table 2).

\section{Aberration of the PI3K/AKT pathway in the cancer of endocrine system}

Thyroid cancer (TC) is the most common malignancy in the endocrine system with a global incidence rate of $3.1 \%$ but a relatively lower lethality $(0.4 \%$, Table 1$)$. In view of the fact that follicular epithelial cell-derived TC accounts for $>95 \%$ of all thyroid malignancies, TC histologically comprises papillary thyroid cancer (PTC), follicular thyroid cancer (FTC), poorly differentiated thyroid cancer (PDTC) and anaplastic thyroid cancer (ATC) [38]. Although PDTC and ATC only account for approximately $5 \%-10 \%$ of TC, but they have brought great clinical challenges since they beget two-thirds of TC-related deaths [39]. Obviously, the overall genetic alterations of PI3K/AKT pathway in TC are inconspicuous (Table 1), but genetic mutations in PI3K/ AKT pathway are common in PDTC and ATC, specifically more common in ATC than in PDTC. Besides PIK3CA (18\% vs. $2 \%)$ and PTEN (15\% vs. $4 \%$ ), mutations of PIK3C2G (6\% vs. $1 \%$ ), PIK3CG (6\% vs. $1 \%$ ), PIK3C3 (0 vs. $1 \%$ ), PIK3R1 (0 vs. $1 \%$ ), PIK3R2 (3\% vs. 0 ), AKT3 (0 vs. $1 \%$ ) are also observed in ATC and PDTC respectively [40]. REC8, TEKT4, ING5, c-Met, HPIP, PIG3, TBX1, CRLF1, INPP4B, MAPK4, miR-34a, -125b, -126, -145, -146b, -148a and -766, as well as IncRNA LINC003121, ABHD11-AS1, H19 and XIST regulate TC cell growth, tumor progression, migration, metastasis or epithelial-mesenchymal transition (EMT) through activating PI3K/AKT pathway [41-61]. Actually, exclusive activating mutations of $B R A F(60 \%$ vs. $33 \%$ and $38 \%$ ) in PTC are more frequently observed than in PDTC and ATC [40], while mice experiments show that co-mutation of $B R A F$ and PIK3CA can promote the development of lethal ATC, but neither BRAF nor PIK3CA mutations alone can [62]. In addition, mutations in $B R A F$ and $P I K 3 C A$ can activate the MAPK pathway and the PI3K/ AKT pathway respectively and lead to the occurrence of ATC, whereas dual blocking PI3K and MAPK pathways can effectively inhibit ATC [63]. Dual PI3K/HDAC inhibitor CUDC-907 inhibits TC growth and metastases, and may be a promising treatment strategy for advanced, metastatic TC [64]. Moreover, whether CUDC-907 was safe and effective in ATC and PDTC patients had been attempted in a 
Table 2 Clinical trial of PI3K Inhibitors in cancers (as of December 2019) (https://clinicaltrials.gov)

\begin{tabular}{|c|c|c|c|c|c|c|}
\hline \multirow[t]{2}{*}{ System } & \multirow[t]{2}{*}{ Cancer } & \multirow[t]{2}{*}{ Subunit } & \multirow[t]{2}{*}{ Inhibitors } & \multirow[t]{2}{*}{ Characteristic } & \multicolumn{2}{|c|}{ Clinical trials } \\
\hline & & & & & Phase & Gov identifier \\
\hline \multirow[t]{6}{*}{ Brain and central nervous } & \multirow[t]{4}{*}{ GBM } & \multirow[t]{2}{*}{ Pan- } & BKM120 & $\begin{array}{l}\text { To assess the safety and the dose of the combination } \\
\text { of INC } 280 \text { and BKM120, as well as the anti-tumor } \\
\text { activity of the combination, in patients with recur- } \\
\text { rent GBM with mutations or homozygous deletion } \\
\text { of PTEN or PTEN negative by IHC }\end{array}$ & $\mathrm{I} / \mathrm{II}$ & NCT01870726 \\
\hline & & & XL147 & $\begin{array}{l}\text { To measure what effect XL147 has on tumor tissue } \\
\text { in subjects with recurrent GBM who are candidates } \\
\text { for surgical resection }\end{array}$ & I & NCT01240460 \\
\hline & & \multirow[t]{2}{*}{ Dual } & GDC-0084 & $\begin{array}{l}\text { To assess the safety, PK and Efficacy of GDC-0084 } \\
\text { in newly-diagnosed GBM }\end{array}$ & II & NCT03522298 \\
\hline & & & XL765 & $\begin{array}{l}\text { To measure what effect XL765 has on tumor tissue } \\
\text { in subjects with recurrent GBM who are candidates } \\
\text { for surgical resection }\end{array}$ & I & NCT01240460 \\
\hline & MBM & Dual & LY3023414 & $\begin{array}{l}\text { To study how well LY3023414 works in treating } \\
\text { patients with recurrent MBM2 }\end{array}$ & II & NCT03213678 \\
\hline & UM & $I S$ & BYL719 & $\begin{array}{l}\text { Phase Ib Trial of AEB071 in combination with } \\
\text { BYL719 in patients with metastatic UM }\end{array}$ & I & NCT02273219 \\
\hline \multirow[t]{3}{*}{ Endocrine } & \multirow[t]{2}{*}{$\mathrm{TC}$} & Pan- & BKM120 & $\begin{array}{l}\text { Evaluating the efficacy and safety of BKM120 in the } \\
\text { treatment of patients with advanced or metastatic } \\
\text { differentiated TC }\end{array}$ & II & NCT01830504 \\
\hline & & Dual & CUDC-907 & $\begin{array}{l}\text { To see if CUDC-907 will shrink tumors in people } \\
\text { with advanced TC }\end{array}$ & II & NCT03002623 \\
\hline & PNETs & $I S$ & BYL719 & $\begin{array}{l}\text { To study the safety and efficacy of BYL719 with } \\
\text { Everolimus or BYL719 with Everolimus and } \\
\text { Exemestane in advanced PNETs }\end{array}$ & I & NCT02077933 \\
\hline \multirow[t]{7}{*}{ Respiratory } & SCLC & Pan- & BKM120 & $\begin{array}{l}\text { Combine BKM120 with cisplatin and etoposide may } \\
\text { kill more tumor cells }\end{array}$ & I & NCT02194049 \\
\hline & \multirow[t]{6}{*}{ NSCLC } & \multirow[t]{6}{*}{ Pan- } & \multirow[t]{4}{*}{ BKM120 } & $\begin{array}{l}\text { BKM120 and pemetrexed disodium may stop the } \\
\text { growth of tumor cells by blocking some of the } \\
\text { enzymes needed for cell growth. Giving BKM120, } \\
\text { carboplatin, and pemetrexed disodium together } \\
\text { may kill more tumor cells }\end{array}$ & I & NCT01723800 \\
\hline & & & & $\begin{array}{l}\text { The safety, tolerability and RP2D of the combination } \\
\text { of gefitinib and BKM120 will be determined }\end{array}$ & I & NCT01570296 \\
\hline & & & & $\begin{array}{l}\text { Giving BKM120, gemcitabine hydrochloride, and } \\
\text { cisplatin may be a better treatment for solid tumors }\end{array}$ & I & NCT01971489 \\
\hline & & & & $\begin{array}{l}\text { To determine the MTD/RP2D of BKM120 in com- } \\
\text { bination with docetaxel. Subsequently the MTD/ } \\
\text { RP2D will be investigated in a Phase II randomized } \\
\text { trial in patients with advanced or metastatic squa- } \\
\text { mous NSCLC }\end{array}$ & I & NCT01911325 \\
\hline & & & GDC-0032 & $\begin{array}{l}\text { To explore the effects of GDC- } 0032 \text { in treating } \\
\text { patients with stage IV squamous cell lung cancer }\end{array}$ & II & NCT02785913 \\
\hline & & & GDC-0941 & $\begin{array}{l}\text { This is an open-label, multicenter, Phase Ib dose- } \\
\text { escalation study to assess the safety, tolerability } \\
\text { and PO of GDC- } 0941\end{array}$ & I & NCT00974584 \\
\hline
\end{tabular}


Table 2 (continued)

\begin{tabular}{|c|c|c|c|c|c|c|}
\hline \multirow[t]{2}{*}{ System } & \multirow[t]{2}{*}{ Cancer } & \multirow[t]{2}{*}{ Subunit } & \multirow[t]{2}{*}{ Inhibitors } & \multirow[t]{2}{*}{ Characteristic } & \multicolumn{2}{|c|}{ Clinical trials } \\
\hline & & & & & Phase & Gov identifier \\
\hline & & $I S$ & CAL-101 & $\begin{array}{l}\text { To determine the safety and effectiveness of the } \\
\text { combination of pembrolizumab and CAL-101 in } \\
\text { NSCLC patients who has stopped responding to } \\
\text { immune therapy and see if adding CAL-101 to } \\
\text { pembrolizumab will increase response rates vs. } \\
\text { pembrolizumab alone }\end{array}$ & $\mathrm{I} / \mathrm{II}$ & NCT03257722 \\
\hline & & & BYL719 & $\begin{array}{l}\text { To evaluate the overall response rate of NSCLC } \\
\text { patients }\end{array}$ & II & NCT02276027 \\
\hline & & & AZD8186 & $\begin{array}{l}\text { To explore the efficacy of AZD8186 as monotherapy } \\
\text { or in combination with abiraterone acetate or } \\
\text { AZD2014 in patients with squamous NSCLC }\end{array}$ & I & NCT01884285 \\
\hline & & Dual & PKI-587 & $\begin{array}{l}\text { Study of PD-0332991 in combination with PKI-587 } \\
\text { for patients with advanced squamous cell lung } \\
\text { solid tumors }\end{array}$ & I & NCT03065062 \\
\hline & & & & $\begin{array}{l}\text { To determine if PKI-587 given in combination with } \\
\text { paclitaxel and carboplatin will work against unre- } \\
\text { sectable NSCLC }\end{array}$ & $\mathrm{I} / \mathrm{II}$ & NCT02920450 \\
\hline & & & LY3023414 & $\begin{array}{l}\text { To find a recommended dose level and schedule of } \\
\text { dosing LY3023414 that can safely be taken by } \\
\text { participants with advanced or metastatic cancer }\end{array}$ & I & NCT01655225 \\
\hline & NPC & Pan- & BKM120 & $\begin{array}{l}\text { To study the SE and BD of BKM120 in combination } \\
\text { with cetuximab and how well it works in treating } \\
\text { patients with recurrent or metastatic head and neck } \\
\text { cancer }\end{array}$ & $\mathrm{I} / \mathrm{II}$ & NCT01816984 \\
\hline & LSCC & Pan- & BKM120 & $\begin{array}{l}\text { To assess tolerability of the combining stand- } \\
\text { ard chemoradiotherapy with weekly cisplatin } \\
\text { and BKM120 in high risk patients with locally } \\
\text { advanced SCCHN }\end{array}$ & I & NCT02113878 \\
\hline \multirow[t]{6}{*}{ Digestive } & ESCC & Pan- & BKM120 & $\begin{array}{l}\text { BKM120 is currently tested in clinical trials, and it } \\
\text { is used for patients with ESCC after failure of first } \\
\text { line chemotherapy }\end{array}$ & II & NCT01806649 \\
\hline & & $I S$ & BYL719 & $\begin{array}{l}\text { During or after palliative first-line platinum-based } \\
\text { chemotherapy, patients with ESCC will be } \\
\text { screened for NGS-based molecular screening. The } \\
\text { patients with the genetic alteration of PI3Ks will be } \\
\text { treated with BYL719 and be observed its efficacy }\end{array}$ & II & NCT03292250 \\
\hline & GC & Pan- & BKM120 & $\begin{array}{l}\text { To determine the MTD and/or RP2D of a combina- } \\
\text { tion of imatinib and BKM120 in the treatment of } \\
\text { 3rd line GIST patients }\end{array}$ & I & NCT01468688 \\
\hline & & $I S$ & GSK2636771 & $\begin{array}{l}\text { To evaluate the safety, PK and clinical activity of } \\
\text { GSK2636771 administered in combination with } \\
\text { Paclitaxel in advanced GC having alterations in } \\
\text { PI3K pathway genes }\end{array}$ & $\mathrm{I} / \mathrm{II}$ & NCT02615730 \\
\hline & & & & $\begin{array}{l}\text { To evaluate the ORR of patients targeted study } \\
\text { agent(s) in patients with advanced refractory } \\
\text { cancers }\end{array}$ & II & NCT02465060 \\
\hline & & & BYL719 & $\begin{array}{l}\text { To investigate the safety of BYL719 and AUY922 in } \\
\text { patients with advanced GC, and to determine the } \\
\text { MTD and/or RDE of both drugs in combination }\end{array}$ & I & NCT01613950 \\
\hline
\end{tabular}


Table 2 (continued)

\begin{tabular}{|c|c|c|c|c|c|c|}
\hline \multirow[t]{2}{*}{ System } & \multirow[t]{2}{*}{ Cancer } & \multirow[t]{2}{*}{ Subunit } & \multirow[t]{2}{*}{ Inhibitors } & \multirow[t]{2}{*}{ Characteristic } & \multicolumn{2}{|c|}{ Clinical trials } \\
\hline & & & & & Phase & Gov identifier \\
\hline & CRC & Pan- & BKM120 & $\begin{array}{l}\text { To determine whether treatment with BKM120 } \\
\text { demonstrates sufficient efficacy in patients with } \\
\text { PI3K-activated tumors, such as CR, OC to warrant } \\
\text { further study }\end{array}$ & II & NCT01833169 \\
\hline & & $I S$ & BYL719 & $\begin{array}{l}\text { To assess the safety and efficacy of LGX818 when } \\
\text { combined with cetuximab or combined with } \\
\text { cetuximab and BYL719 in patients with BRAF } \\
\text { mutant metastatic CRC }\end{array}$ & $\mathrm{I} / \mathrm{II}$ & NCT01719380 \\
\hline & & & TAK-117 & $\begin{array}{l}\text { To test if combining TAK- } 117 \text { with canagliflozin } \\
\text { will improve efficacy in the treatment of advanced } \\
\text { solid tumors }\end{array}$ & $\mathrm{I} / \mathrm{II}$ & NCT04073680 \\
\hline & & Dual & DS-7423 & $\begin{array}{l}\text { To determine the MTD and measure the effects of } \\
\text { DS- } 7423 \text { on the patients with advanced CRC }\end{array}$ & I & NCT01364844 \\
\hline & & & LY3023414 & $\begin{array}{l}\text { To evaluate the safety of LY3039478 in combination } \\
\text { with other anticancer agents including LY3023414 } \\
\text { in participants with advanced or metastatic solid } \\
\text { tumors }\end{array}$ & I & NCT02784795 \\
\hline & GIST & Pan- & BKM120 & $\begin{array}{l}\text { To determine the MTD and/or RP2D of a combina- } \\
\text { tion of imatinib and BKM120 in the treatment of } \\
\text { 3rd line GIST patients }\end{array}$ & I & NCT01468688 \\
\hline & & $I S$ & BYL719 & $\begin{array}{l}\text { To determine the MTD and/or RP2D of a combina- } \\
\text { tion of imatinib and BYL719 in the treatment of } \\
\text { 3rd line GIST patients }\end{array}$ & I & NCT01735968 \\
\hline & $\mathrm{HCC}$ & Dual & SF1126 & $\begin{array}{l}\text { To determine the MTD or MRD and the RP2D of } \\
\text { SF1126 in combination with nivolumab in adult } \\
\text { patients with advanced HCC }\end{array}$ & I & NCT03059147 \\
\hline & & $I S$ & GSK2636771 & $\begin{array}{l}\text { To evaluate the ORR of patients targeted study } \\
\text { agent(s) in patients with advanced refractory } \\
\text { cancers }\end{array}$ & II & NCT02465060 \\
\hline & PC & Pan- & BKM120 & $\begin{array}{l}\text { To investigate the safety, PK and PD of BKM120 } \\
\text { plus GSK1120212 in advanced } R A S \text { or } B R A F \\
\text { mutant PC patients }\end{array}$ & I & NCT01155453 \\
\hline & & & & $\begin{array}{l}\text { To investigate the safety, PK and PD of BKM120 } \\
\text { plus MEK } 162 \text { in advanced } R A S \text { or } B R A F \text { mutant } \\
\text { PC patients }\end{array}$ & I & NCT01363232 \\
\hline & & $I S$ & GSK2636771 & $\begin{array}{l}\text { To evaluate the ORR of patients targeted study } \\
\text { agent(s) in patients with advanced refractory } \\
\text { cancers }\end{array}$ & II & NCT02465060 \\
\hline & & & BYL719 & $\begin{array}{l}\text { To see primarily if BYL719 is safe to be given to } \\
\text { patients in combination with gemcitabine and nab- } \\
\text { paclitaxel in locally advanced and metastatic PC }\end{array}$ & I & NCT02155088 \\
\hline & & Dual & PKI-587 & $\begin{array}{l}\text { To study PD-0332991 in combination with PKI-587 } \\
\text { for patients with advanced PC solid tumors }\end{array}$ & I & NCT03065062 \\
\hline & & & BEZ235 & $\begin{array}{l}\text { To study the safety, PK and PD of BEZ235 Plus } \\
\text { MEK162 in advanced PC solid tumor patients }\end{array}$ & I & NCT01337765 \\
\hline & & & LY3023414 & $\begin{array}{l}\text { To evaluate the safety and efficacy of abemaciclib } \\
\text { alone and in combination with other drugs includ- } \\
\text { ing LY3023414 in participants with previously } \\
\text { treated metastatic PDAC }\end{array}$ & II & NCT02981342 \\
\hline \multirow[t]{2}{*}{ Reproductive } & $\mathrm{BC}$ & Pan- & BKM120 & $\begin{array}{l}\text { Evaluating the clinical activity of BKM120 in } \\
\text { patients with metastatic TNBC }\end{array}$ & II & NCT01629615 \\
\hline & & & & $\begin{array}{l}\text { Evaluating BKM120 in combination with trastu- } \\
\text { zumab and paclitaxel in HER } 2+\text { primary BC }\end{array}$ & II & NCT01816594 \\
\hline
\end{tabular}


Table 2 (continued)

System Cancer Subunit Inhibitors Characteristic

Clinical trials

Phase Gov identifier

Evaluating the safety profile/tolerability and prelimi- I

NCT01248494 nary anti-tumor effect of BKM120 and endocrine therapy combination and BEZ235 and endocrine therapy combination in postmenopausal patients with $\mathrm{HR}+\mathrm{MBC}$

To determine whether treatment with BKM120 plus letrozole led to an increase in pathologic clinical response and ORR compared to treatment with placebo plus letrozole in patients with $\mathrm{BC}$

To assess the MTD and/or RP2Ds, safety and tolerability, the single and multiple dose PK profile and assess the preliminary antitumor activity of BYL719 and BKM120 in combination with tamoxifen plus goserelin acetate in premenopausal advanced $\mathrm{HR}+\mathrm{BC}$ patients

BKM120 and anti-HER2 therapy may have a synergistic antitumor activity in preclinical model of HER2 + BC

To determine the MTD and /or RP2D and schedule for BKM120 given in combination with GSK1120212 in patients with selected, advanced solid tumors

Inhibition of PI3K by BKM120 may enhance apoptosis in ER + BC cells

To look for MTD, and also to see if the combination of BKM120 or BYL719 and olaparib is effective in treating $\mathrm{BC}$

To explore the efficacy and safety of BKM120 in combination with tamoxifen in patients with ER/ $\mathrm{PR}+$, HER2- BC with prior exposure to antihormonal therapy

To determine the efficacy and safety of treatment with BKM120 plus Fulvestrant vs. Placebo plus Fulvestrant in postmenopausal women with $\mathrm{HR}+$, HER2-, AI-treated, locally MBC whose disease progressed on or after mTORi-based treatment

Consistent, dose-dependent PD activity has been demonstrated and clear signs of anti-tumor activity have been seen with BKM120

GDC-0941 Examining how well the combination of GDC-0941 and cisplatin work in treating patients with metastatic AR- TNBC

Assessing the safety, tolerability and efficacy of GDC-0032 or GDC-0941, in combination with PAlbociclib, with the subsequent addition of Fulvestrant in PIK3CA-mutant BCs

To assess the safety, tolerability, and PO of pictilisib I administered with letrozole or IV paclitaxel with and without IV bevacizumab or IV trastuzumab in participants with locally recurrent or metastatic BC 
Table 2 (continued)

\begin{tabular}{|c|c|c|c|c|}
\hline \multirow[t]{2}{*}{ System } & \multirow{2}{*}{ Cancer } & \multirow{2}{*}{ Subunit Inhibitors } & \multirow{2}{*}{ Characteristic } & Clinical trials \\
\hline & & & & Phase Gov identifier \\
\hline
\end{tabular}

GDC 0032 GDC 0032 is given together with enzalutamide and to see how well they work in treating patients with metastasis AR+TNBC

Assessing the safety, tolerability and efficacy of GDC-0032 or GDC-0941, in combination with PAlbociclib, with the subsequent addition of Fulvestrant in PIK3CA-mutant BCs

To determine RP2D of GDC-0032 plus tamoxifen in HR + , HER2-MBC patients who have progressed after prior endocrine treatment

BAY 80-6946 To study the SE and how well BAY 80-6946 works when given together with fulvestrant in treating postmenopausal patients with ER + and HER2- BC that has spread to other places in the body and progressing after prior treatment

The addition of BAY 80-6946 to the usual treatment (trastuzumab and pertuzumab) could shrink the cancer or stabilize it for longer duration as compared to the usual treatment alone

Adding BAY 80-6946 to the usual therapy of Fulvestrant and abemaciclib may work better than giving Fulvestrant and abemaciclib alone in treating patients with $\mathrm{BC}$

BAY 80-6946 may stop the growth of tumor cells by blocking some of the enzymes needed for cell

I/II NCT02457910 growth

Giving BAY 80-6946, letrozole, and palbociclib may work better in treating patients with $\mathrm{BC}$

BYL719 in combination with letrozole may kill more I tumor cells

BYL719 is an oral drug that may help T-DM1 to work better

Determining the MTD, safety and effectiveness of BYL719 combined with Nab-Paclitaxel in treating patients with HER2-BC, along with the determination of how long this drug combination will keep the disease from getting worse

A Study of BYL719 in combination with paclitaxel in advanced solid tumors followed by two expansion phases in locally chemotherapy naive HER2MBC patients and in recurrent and metastatic HNSCC patients pre-treated with platinum-based therapy

To determine whether treatment with BYL719 plus letrozole led to an increase in pathologic clinical response and ORR compared to treatment with placebo plus letrozole in patients with $\mathrm{BC}$

To assess the MTD and/or the RP2D(s), safety, tolerability, the single and multiple dose PK profile and the preliminary anti-tumor activity of BYL719 and BKM120 in combination with tamoxifen plus goserelin acetate in premenopausal advanced $\mathrm{HR}+\mathrm{BC}$ patients

To describe safety and tolerability of the BYL719 
Table 2 (continued)

System Cancer Subunit Inhibitors Characteristic

Clinical trials

Phase Gov identifier

To study BYL719 monotherapy in adult patients with II advanced MBC progressing after first line therapy

BKM120, BYL719 and olaparib are drugs that may stop cancer cells from growing abnormally

BYL719 may stop the growth of tumor cells by blocking some of the enzymes needed for cell growth

Assessing the efficacy and safety of BYL719 plus Fulvestrant or letrozole, based on prior endocrin therapy, in patients with PIK3CA mutation with advanced $\mathrm{BC}$ who have progressed on or after prior treatments

To investigate combination of BYL719 with Fulvestrant in post-menopausal patients with locally advanced or $\mathrm{MBC}$ whose tumors have an alteration of the PIK $3 C A$ gene

MEN1611

To identify the appropriate dose of MEN1611 to be used in combination with Trastuzumab with/without Fulvestrant for the treatment of HER2 + MBC

BAY80-6946 It will determine the MTD and the RP2D of BAY80- I 6946 in combination with paclitaxel

XL147

Phase 1 will evaluate the MTD of XL147 or XL765 when given in combination with letrozole. Phase 2 will evaluate the efficacy and safety of these combinations in subjects with BC refractory to a non-steroidal aromatase inhibitor that is $\mathrm{ER}+1$ PGR + and HER2-

TAK-117

To test if combining TAK-117 with canagliflozin will improve efficacy in the treatment of advanced solid tumors

Dual BEZ235

LY3023414

F-04691502

Evaluating the safety profile/tolerability and preliminary anti-tumor effect of BKM120 and endocrine therapy combination and BEZ235 and endocrine therapy combination in postmenopausal patients with $\mathrm{HR}+\mathrm{MBC}$

This is a first-in-human, phase I/Ib clinical research study with BEZ235

CUDC-907 Evaluating the safety, tolerability and PK of CUDC907 administered orally to subjects with advanced/ relapsed solid tumors

II investigate the safety of prexasertib in combination with other anti-cancer drugs including LY3023414 in participants with advanced or metastatic cancer

The combination of PF-04691502 and exemestane

NCT03207529

NCT03056755 might mitigate resistance to hormonal therapy and result in greater clinical benefit than exemestane alone in women with advanced ER + BC

Published data support the hypothesis that a PF-04691502 in combination with letrozole might mitigate the intrinsic or acquired resistance to hormonal therapy and restore hormone sensitivity in high risk patient population of hormone-sensitive BCs 
Table 2 (continued)

\begin{tabular}{|c|c|c|c|c|c|c|}
\hline \multirow[t]{2}{*}{ System } & \multirow[t]{2}{*}{ Cancer } & \multirow[t]{2}{*}{ Subunit } & \multirow[t]{2}{*}{ Inhibitors } & \multirow[t]{2}{*}{ Characteristic } & \multicolumn{2}{|c|}{ Clinical trials } \\
\hline & & & & & Phase & Gov identifier \\
\hline & & & PKI-587 & $\begin{array}{l}\text { Preclinical and first-in-human studies have shown a } \\
\text { manageable safety profile with predictable toxicity } \\
\text { for this class of drugs }\end{array}$ & I & NCT02626507 \\
\hline & & & XL765 & $\begin{array}{l}\text { Phase } 1 \text { will evaluate the MTD of XL147 or XL765 } \\
\text { when given in combination with letrozole. Phase } \\
2 \text { will evaluate the efficacy and safety of these } \\
\text { combinations in subjects with BC refractory to } \\
\text { a non-steroidal aromatase inhibitor that is ER +/ } \\
\text { PGR + and HER2- }\end{array}$ & $\mathrm{I} / \mathrm{II}$ & NCT01082068 \\
\hline & & & PQR309 & $\begin{array}{l}\text { To evaluate clinical safety, efficacy and PK of } \\
\text { PQR309 in combination with standard dose of } \\
\text { eribulin in patients with locally advanced or meta- } \\
\text { static HER2-TNBC }\end{array}$ & $\mathrm{I} / \mathrm{II}$ & NCT02723877 \\
\hline & $\mathrm{OC}$ & Pan- & BAY 80-6946 & $\begin{array}{l}\text { Niraparib and BAY } 80-6946 \text { may stop the growth } \\
\text { of tumor cells by blocking some of the enzymes } \\
\text { needed for cell growth }\end{array}$ & I & NCT03586661 \\
\hline & & & BKM120 & $\begin{array}{l}\text { To look for MTD, and also to see if the combination } \\
\text { of BKM120 or BYL } 719 \text { and olaparib is effective in } \\
\text { treating OC }\end{array}$ & I & NCT01623349 \\
\hline & & $I S$ & BYL719 & $\begin{array}{l}\text { To look for MTD, and also to see if the combination } \\
\text { of BKM120 or BYL } 719 \text { and olaparib is effective in } \\
\text { treating OC }\end{array}$ & I & NCT01623349 \\
\hline & & Dual & CUDC-907 & $\begin{array}{l}\text { Evaluating the safety, tolerability and PK of CUDC- } \\
907 \text { administered orally to subjects with advanced/ } \\
\text { relapsed solid tumors }\end{array}$ & I & NCT02307240 \\
\hline & FTC & Pan- & BAY 80-6946 & $\begin{array}{l}\text { Niraparib and BAY 80-6946 may stop the growth } \\
\text { of tumor cells by blocking some of the enzymes } \\
\text { needed for cell growth }\end{array}$ & I & NCT03586661 \\
\hline & EC & Pan- & BAY 80-6946 & $\begin{array}{l}\text { Niraparib and BAY 80-6946 may stop the growth } \\
\text { of tumor cells by blocking some of the enzymes } \\
\text { needed for cell growth }\end{array}$ & I & NCT03586661 \\
\hline & & & & $\begin{array}{l}\text { BAY } 80-6946 \text { may stop the growth of tumor cells } \\
\text { by blocking some of the enzymes needed for cell } \\
\text { growth }\end{array}$ & II & NCT02728258 \\
\hline & & $I S$ & TAK-117 & $\begin{array}{l}\text { To test the hypothesis that combining TAK- } 117 \\
\text { with canagliflozin will improve efficacy in treating } \\
\text { patients with advanced EC }\end{array}$ & $\mathrm{I} / \mathrm{II}$ & NCT04073680 \\
\hline & & & MLN1117 & $\begin{array}{l}\text { Study of MLN0128, combination of MLN0128 } \\
\text { with MLN1117, Paclitaxel and combination of } \\
\text { MLN0128 with Paclitaxel in women with EC }\end{array}$ & II & NCT02725268 \\
\hline & & Dual & PF-04691502 & $\begin{array}{l}\text { To investigate the individual safety and efficacy of } \\
\text { PF-04691502 in patients with recurrent EC }\end{array}$ & II & NCT01420081 \\
\hline & & & PKI-587 & $\begin{array}{l}\text { To investigate the individual safety and efficacy of } \\
\text { PKI-587 in patients with recurrent EC }\end{array}$ & II & NCT01420081 \\
\hline & & & LY3023414 & $\begin{array}{l}\text { To determine the effectiveness and the side effects of } \\
\text { LY3023414 in treating the EC }\end{array}$ & II & NCT02549989 \\
\hline & & & DS-7423 & $\begin{array}{l}\text { To determine the MTD in subjects with advanced } \\
\text { solid tumors and measure the effects of DS- } 7423 \\
\text { on the patients with advanced EC }\end{array}$ & I & NCT01364844 \\
\hline
\end{tabular}


Table 2 (continued)

\begin{tabular}{|c|c|c|c|c|c|c|}
\hline \multirow[t]{2}{*}{ System } & \multirow[t]{2}{*}{ Cancer } & \multirow[t]{2}{*}{ Subunit } & \multirow[t]{2}{*}{ Inhibitors } & \multirow[t]{2}{*}{ Characteristic } & \multicolumn{2}{|c|}{ Clinical trials } \\
\hline & & & & & Phase & Gov identifier \\
\hline \multirow[t]{9}{*}{ Genitourinary } & \multirow[t]{5}{*}{$\mathrm{PCa}$} & Pan- & BKM120 & $\begin{array}{l}\text { To evaluate BKM120 with cabazitaxel in the treat- } \\
\text { ment of patients with advanced PCa }\end{array}$ & II & NCT02035124 \\
\hline & & \multirow[t]{2}{*}{$I S$} & AZD8186 & $\begin{array}{l}\text { To explore the efficacy of AZD8186 as monotherapy } \\
\text { or in combination with abiraterone acetate or } \\
\text { AZD2014 in patients with CRPC }\end{array}$ & I & NCT01884285 \\
\hline & & & GSK2636771 & $\begin{array}{l}\text { To determine the RP2D for the combination } \\
\text { GSK2636771 with enzalutamide in male subjects } \\
\text { with metastatic CRPC }\end{array}$ & I & NCT02215096 \\
\hline & & \multirow[t]{2}{*}{ Dual } & LY3023414 & $\begin{array}{l}\text { To evaluate the safety and effectiveness of } \\
\text { LY3023414 in combination with enzalutamide in } \\
\text { men with PCa }\end{array}$ & II & NCT02407054 \\
\hline & & & GDC-0980 & $\begin{array}{l}\text { Phase } \mathrm{Ib} \text { is to determine RP2D of ipataseritib } \\
\text { administrated in combination with abiraterone and } \\
\text { of GDC- } 0980 \text { administrated in combination with } \\
\text { abiraterone }\end{array}$ & $\mathrm{I} / \mathrm{II}$ & NCT01485861 \\
\hline & \multirow[t]{2}{*}{$\mathrm{RCC}$} & \multirow[t]{2}{*}{$I S$} & BYL719 & $\begin{array}{l}\text { To describe safety and tolerability of the BYL719 } \\
\text { and everolimus or BYL719, everolimus and } \\
\text { exemestane combinations }\end{array}$ & I & NCT02077933 \\
\hline & & & MLN1117 & $\begin{array}{l}\text { To evaluate the efficacy and safety of single- } \\
\text { agent MLN0128 and the combination of } \\
\text { MLN0128 + MLN1117 compared with everolimus } \\
\text { in the treatment of adults with advanced or meta- } \\
\text { static Clear-Cell RCC }\end{array}$ & II & NCT02724020 \\
\hline & \multirow[t]{2}{*}{ BLCA } & Pan- & BKM120 & $\begin{array}{l}\text { To learn what effects, good and/or bad, BKM120 has } \\
\text { on advanced urothelial cancer }\end{array}$ & II & NCT01551030 \\
\hline & & $I S$ & GSK2636771 & $\begin{array}{l}\text { To evaluate the ORR of patients targeted study } \\
\text { agent(s) in patients with advanced refractory } \\
\text { cancers }\end{array}$ & II & NCT02465060 \\
\hline \multirow[t]{7}{*}{ Hematologic } & \multirow[t]{7}{*}{ Lymphoma } & \multirow[t]{4}{*}{ Pan- } & \multirow[t]{3}{*}{ BAY80-6946 } & $\begin{array}{l}\text { To study the SE and BD of BAY } 80-6946 \text { and } \\
\text { nivolumab in treating patients with metastatic solid } \\
\text { tumors or lymphoma }\end{array}$ & I & NCT03502733 \\
\hline & & & & $\begin{array}{l}\text { To investigate safe, feasible and beneficial of } \\
\text { BAY80-6946 in pediatric patients with recurrent or } \\
\text { refractory lymphoma }\end{array}$ & $\mathrm{I} / \mathrm{II}$ & NCT03458728 \\
\hline & & & & $\begin{array}{l}\text { To evaluate the ORR of patients targeted study } \\
\text { agent(s) in patients with advanced refractory } \\
\text { cancers }\end{array}$ & II & NCT02465060 \\
\hline & & & BKM120 & $\begin{array}{l}\text { To find out what effects, good and/or bad, BKM120 } \\
\text { has on lymphoma and the central nervous system }\end{array}$ & II & NCT02301364 \\
\hline & & \multirow[t]{3}{*}{$I S$} & TGR-1202 & $\begin{array}{l}\text { Phase I is to determine the MTD, DLT, safety and } \\
\text { toxicity of the combinations of TGR-1202 and } \\
\text { carfilzomib in participants with R/R NHL and HL. } \\
\text { If the combination is found to be feasible, phase II } \\
\text { consisting of a 2-stage design of the combination } \\
\text { will be initiated }\end{array}$ & $\mathrm{I} / \mathrm{II}$ & NCT02867618 \\
\hline & & & \multirow[t]{2}{*}{ IPI-145 } & $\begin{array}{l}\text { To evaluate the safety and PK of IPI-145 in Japanese } \\
\text { participants with R/R lymphoma }\end{array}$ & I & NCT02598570 \\
\hline & & & & $\begin{array}{l}\text { To characterize the safety, MTD and preliminary } \\
\text { efficacy profile of IPI- } 145 \text { given in combination } \\
\text { with rituximab, or bendamustine plus rituximab, to } \\
\text { subjects with select R/R hematologic malignancies }\end{array}$ & I & NCT01871675 \\
\hline
\end{tabular}


Table 2 (continued)

\begin{tabular}{|c|c|c|c|c|c|c|}
\hline \multirow[t]{2}{*}{ System } & \multirow[t]{2}{*}{ Cancer } & \multirow[t]{2}{*}{ Subunit } & \multirow[t]{2}{*}{ Inhibitors } & \multirow[t]{2}{*}{ Characteristic } & \multicolumn{2}{|c|}{ Clinical trials } \\
\hline & & & & & Phase & Gov identifier \\
\hline & & Dual & PQR309 & $\begin{array}{l}\text { To determine the MTD, RP2D and preliminary anti- } \\
\text { tumor activity of PQR309 administered orally, as } \\
\text { once daily capsules continuously and on intermit- } \\
\text { tent schedule in patients with R/R lymphomas }\end{array}$ & II & NCT02249429 \\
\hline & & & VS-5584 & $\begin{array}{l}\text { To evaluate the safety (including the RP2D), PK and } \\
\text { the anti-cancer activity of VS-5584 }\end{array}$ & I & NCT01991938 \\
\hline & & & WX390 & $\begin{array}{l}\text { WX390 is a novel oral small molecular that has } \\
\text { demonstrated potent inhibitory effects on multiple } \\
\text { human tumor xenografts }\end{array}$ & I & NCT03730142 \\
\hline & & & GSK1059615 & $\begin{array}{l}\text { To define the RP2D, toxicity profile, PK and biologi- } \\
\text { cally active dose range of GSK1059615 }\end{array}$ & I & NCT00695448 \\
\hline & & & CUDC-907 & $\begin{array}{l}\text { To assess the safety, tolerability and PK of orally } \\
\text { Administered CUDC-907 in subjects with R/R } \\
\text { lymphoma }\end{array}$ & $\mathrm{I} / \mathrm{II}$ & NCT01742988 \\
\hline & & & GSK2126458 & $\begin{array}{l}\text { To determine the RP2D of GSK2126458 based on } \\
\text { safety and tolerability, PK, PD and preliminary } \\
\text { evidence of clinical activity }\end{array}$ & I & NCT00972686 \\
\hline & HL & $I S$ & TGR-1202 & $\begin{array}{l}\text { To evaluate the safety and effectiveness of TGR- } \\
1202 \text { in combination with brentuximab vedotin in } \\
\text { patients with HL }\end{array}$ & I & NCT02164006 \\
\hline & & & RP6530 & $\begin{array}{l}\text { To evaluate safety, tolerability and to establish the } \\
\text { MTD for RP6530 in combination with Pembroli- } \\
\text { zumab in patients with CHL }\end{array}$ & $\mathrm{I} / \mathrm{II}$ & NCT03471351 \\
\hline & NHL & Pan- & BAY80-6946 & $\begin{array}{l}\text { BAY80-6946 in combination with standard immuno- } \\
\text { chemotherapy } v s \text {. standard immunochemotherapy } \\
\text { in patients with relapsed iNHL }\end{array}$ & III & NCT02626455 \\
\hline & & & & $\begin{array}{l}\text { To assess the safety of BAY80-6946 in Rituximab- } \\
\text { refractory iNHL }\end{array}$ & III & NCT02369016 \\
\hline & & & & $\begin{array}{l}\text { Part A is to evaluate the efficacy and safety of } \\
\text { BAY80-6946 in patients with indolent or aggres- } \\
\text { sive NHL, who have progressed after standard } \\
\text { therapy. Part B is to evaluate the efficacy and safety } \\
\text { of BAY80-6946 in patients with R/R FL }\end{array}$ & II & NCT01660451 \\
\hline & & & & $\begin{array}{l}\text { To study BD and how well BAY80-6946 plus } \\
\text { nivolumab works in patients with Richter's trans- } \\
\text { formation or transformed iNHL }\end{array}$ & I & NCT03884998 \\
\hline & & & & $\begin{array}{l}\text { To study the BD of BAY } 80-6946 \text { plus chemotherapy } \\
\text { in patients with R/R DLBCL or relapsed grade } 3 \mathrm{~b} \\
\text { FL after } 1 \text { prior line therapy }\end{array}$ & I & NCT04156828 \\
\hline & & & BKM120 & $\begin{array}{l}\text { BKM may stop the growth of cancer cells by block- } \\
\text { ing some of the enzymes needed for cell growth }\end{array}$ & I & NCT01719250 \\
\hline & & & GDC-0941 & $\begin{array}{l}\text { To assess the safety, tolerability, and PK of orally } \\
\text { administered GDC-0941 administered QD }\end{array}$ & I & NCT00876122 \\
\hline & & & GDC-0032 & $\begin{array}{l}\text { To assess the safety, tolerability, and PK of GDC- } \\
0032 \text { in participants with NHL }\end{array}$ & I & NCT01296555 \\
\hline
\end{tabular}


Table 2 (continued)

\begin{tabular}{|c|c|c|c|c|c|c|}
\hline \multirow[t]{2}{*}{ System } & \multirow[t]{2}{*}{ Cancer } & \multirow[t]{2}{*}{ Subunit } & \multirow[t]{2}{*}{ Inhibitors } & \multirow[t]{2}{*}{ Characteristic } & \multicolumn{2}{|c|}{ Clinical trials } \\
\hline & & & & & Phase & Gov identifier \\
\hline & & $I S$ & IPI-145 & $\begin{array}{l}\text { To assess the safety, PK, drug-drug interactions, and } \\
\text { RP2D of co administered IPI-145 and Venetoclax } \\
\text { in subjects with R/R CLL/SLL or iNHL who have } \\
\text { not previously received a Bcl- } 2 \text { or PI3K Inhibitor }\end{array}$ & I & NCT02640833 \\
\hline & & & & $\begin{array}{l}\text { Examine the effects of predefined } 2 \text { weeks IPI- } 145 \\
\text { dose holidays on tumor responses and safety/toler- } \\
\text { ability }\end{array}$ & II & NCT04038359 \\
\hline & & & & $\begin{array}{l}\text { To evaluate the safety and efficacy of IPI- } 145 \text { in } \\
\text { subjects with iNHL that is refractory to rituximab } \\
\text { and to either chemotherapy or RIT }\end{array}$ & II & NCT01882803 \\
\hline & & & & $\begin{array}{l}\text { To evaluate the efficacy and safety of DBR vs PBR } \\
\text { in subjects with previously-treated iNHL }\end{array}$ & III & NCT02576275 \\
\hline & & & CAL-101 & $\begin{array}{l}\text { To evaluate the efficacy, safety, tolerability, and PD } \\
\text { of entospletinib and CAL-101 }\end{array}$ & II & NCT01796470 \\
\hline & & & & $\begin{array}{l}\text { To evaluate the addition of CAL- } 101 \text { to bendamus- } \\
\text { tine/rituximab on PFS in adults with previously } \\
\text { treated iNHL }\end{array}$ & III & NCT01732926 \\
\hline & & & RP6530 & $\begin{array}{l}\text { To assess the anti-tumor activity and safety of } \\
\text { RP6530 in patients with R/R iNHL }\end{array}$ & II & NCT03711578 \\
\hline & & & TGR-1202 & $\begin{array}{l}\text { To evaluate the safety and effectiveness of Ublituxi- } \\
\text { mab in combination with TGR-1202, with or } \\
\text { without ibrutinib or bendamustine, in patients with } \\
\text { advanced hematologic malignancies }\end{array}$ & I & NCT02006485 \\
\hline & & Dual & PQR309 & $\begin{array}{l}\text { With a safety run-in evaluating efficacy and safety of } \\
\text { PQR309 in patients with R/R Lymphoma }\end{array}$ & II & NCT03127020 \\
\hline & & Dual & LY3023414 & $\begin{array}{l}\text { To study how well LY3023414 works in treating } \\
\text { patients with recurrent NHL }\end{array}$ & II & NCT03213678 \\
\hline & BCL & Pan- & BKM120 & $\begin{array}{l}\text { BKM120 may stop the growth of cancer cells and } \\
\text { when it together with rituximab may be an effective } \\
\text { treatment for BCL }\end{array}$ & I & NCT02049541 \\
\hline & & & BAY80-6946 & $\begin{array}{l}\text { To evaluate whether copanlisib plus rituximab is } \\
\text { superior to placebo plus rituximab in prolonging } \\
\text { PFS in patients with relapsed iNHL }\end{array}$ & III & NCT02367040 \\
\hline & & & & $\begin{array}{l}\text { To establish the MTD and RP2D of BAY80-6946 in } \\
\text { combination with venetoclax in patients with R/R } \\
\text { B-cell NHL }\end{array}$ & I & NCT03886649 \\
\hline
\end{tabular}


Table 2 (continued)

\begin{tabular}{|c|c|c|c|c|c|c|}
\hline \multirow[t]{2}{*}{ System } & \multirow[t]{2}{*}{ Cancer } & \multirow[t]{2}{*}{ Subunit } & \multirow[t]{2}{*}{ Inhibitors } & \multirow[t]{2}{*}{ Characteristic } & \multicolumn{2}{|c|}{ Clinical trials } \\
\hline & & & & & Phase & Gov identifier \\
\hline & & $I S$ & CAL-101 & $\begin{array}{l}\text { To evaluate the safety of CAL-101 as post-transplan- } \\
\text { tation maintenance in patients with BCL undergo- } \\
\text { ing an allogeneic HSCT }\end{array}$ & I & NCT03151057 \\
\hline & & & & $\begin{array}{l}\text { To assess the overall response rate, the efficacy and } \\
\text { safety of CAL-101 in participants with previously } \\
\text { treated iNHL that is refractory both to rituximab } \\
\text { and to alkylating-agent-containing chemotherapy }\end{array}$ & II & NCT01282424 \\
\hline & & & RP6530 & $\begin{array}{l}\text { To evaluate the safety and efficacy of RP6530 in } \\
\text { patients with hematologic malignancies }\end{array}$ & I & NCT02017613 \\
\hline & & & KA2237 & $\begin{array}{l}\text { To evaluate safety/tolerability, PK and PD effects of } \\
\text { KA2237 in patients with BCL and determine the } \\
\text { MTD in Part I of the study. In Part II, patients with } \\
\text { BCL will be treated with KA2237 at the MTD to } \\
\text { evaluate safety and efficacy in the patient popula- } \\
\text { tion }\end{array}$ & I & NCT02679196 \\
\hline & & & YY-20394 & $\begin{array}{l}\text { To assess the tolerability, PK and efficacy of } \\
\text { YY-20394 in patients with relapse or refractory } \\
\text { BCL }\end{array}$ & I & NCT03757000 \\
\hline & & & TGR-1202 & $\begin{array}{l}\text { TGR-1202 and ibrutinib may stop the growth of can- } \\
\text { cer cells by blocking some of the enzymes needed } \\
\text { for cell growth }\end{array}$ & II & NCT02874404 \\
\hline & TCL & $I S$ & RP6530 & $\begin{array}{l}\text { Evaluating the safety, PK and efficacy of RP6530 in } \\
\text { patients with R/R TCL }\end{array}$ & I & NCT02567656 \\
\hline & & & & $\begin{array}{l}\text { To evaluate the safety and efficacy of RP6530 in } \\
\text { patients with hematologic malignancies }\end{array}$ & I & NCT02017613 \\
\hline & & & & $\begin{array}{l}\text { To characterize safety, tolerability and to estab- } \\
\text { lish the MTD of RP6530 in combination with } \\
\text { Romidepsin in patients with R/R TCL }\end{array}$ & $\mathrm{I} / \mathrm{II}$ & NCT03770000 \\
\hline & & & IPI-145 & This is a study of IPI-145 in patients with R/R PTCL & II & NCT03372057 \\
\hline & & & & $\begin{array}{l}\text { To determine the MTD of IPI- } 145 \text { with romidepsin } \\
\text { and IPI-145 with bortezomib in R/R TCL }\end{array}$ & I & NCT02783625 \\
\hline & FL & Pan- & BAY80-6946 & $\begin{array}{l}\text { Part B is to evaluate the efficacy and safety of } \\
\text { BAY80-6946 in patients with R/R FL }\end{array}$ & II & NCT01660451 \\
\hline & & & & $\begin{array}{l}\text { To see if BAY } 80-6946 \text { plus rituximab is effective at } \\
\text { slowing the growth of FL }\end{array}$ & II & NCT03789240 \\
\hline & & $I S$ & IPI-145 & $\begin{array}{l}\text { To evaluate the safety and efficacy of IPI-145 admin- } \\
\text { istered in combination with rituximab vs. placebo } \\
\text { in combination with rituximab in patients with } \\
\text { previously treated CD20+FL who are not suitable } \\
\text { candidates for chemotherapy }\end{array}$ & III & NCT02204982 \\
\hline & & & & $\begin{array}{l}\text { To evaluate the safety and efficacy of IPI- } 145 \text { in } \\
\text { combination with rituximab or obinutuzumab in } \\
\text { subjects with untreated CD } 20+\text { FL }\end{array}$ & $\mathrm{I} / \mathrm{II}$ & NCT02391545 \\
\hline & & & TGR-1202 & $\begin{array}{l}\text { To determine the overall response rate of TGR- } 1202 \\
\text { in FL }\end{array}$ & II & NCT03178201 \\
\hline & & & CAL-101 & $\begin{array}{l}\text { To establish a safe and effective dosing regimen of } \\
\text { CAL-101 in participants with R/R FL who have no } \\
\text { other therapeutic options }\end{array}$ & III & NCT02536300 \\
\hline & & & INCB050465 & $\begin{array}{l}\text { To assess the ORR of INCB050465 treatment in } \\
\text { subjects with R/R FL }\end{array}$ & II & NCT03126019 \\
\hline & & & ME-401 & $\begin{array}{l}\text { A Three-Arm Study of ME- } 401 \text { in subjects with R/R } \\
\text { FL or CLL/SLL }\end{array}$ & I & NCT02914938 \\
\hline
\end{tabular}


Table 2 (continued)

\begin{tabular}{|c|c|c|c|c|c|c|}
\hline \multirow[t]{2}{*}{ System } & \multirow[t]{2}{*}{ Cancer } & \multirow[t]{2}{*}{ Subunit } & \multirow[t]{2}{*}{ Inhibitors } & \multirow[t]{2}{*}{ Characteristic } & \multicolumn{2}{|c|}{ Clinical trials } \\
\hline & & & & & Phase & Gov identifier \\
\hline & NK/TCL & Pan- & BAY80-6946 & $\begin{array}{l}\text { BAY 80-6946 has demonstrated activity in R/R, } \\
\text { aggressive NHLs, suggesting an ORR of } 50 \% \text { for } \\
\text { TCL. BAY 80-6946 plus gemcitabine will exhibit } \\
\text { early elimination of rapidly growing tumor cells } \\
\text { and be a rational therapeutic modality for use in } \\
\text { R/R PTCLs, if the overlapping toxicities can be } \\
\text { managed }\end{array}$ & $\mathrm{I} / \mathrm{II}$ & NCT03052933 \\
\hline & CLL/SLL & Pan- & BAY80-6946 & $\begin{array}{l}\text { To study how well bendamustine and rituximab in } \\
\text { combination with BAY80-6946 work in treating } \\
\text { patients with CLL/SLL }\end{array}$ & II & NCT04155840 \\
\hline & & & BKM120 & To find out the effects of BKM120 in CLL & II & NCT02340780 \\
\hline & & $I S$ & CAL-101 & $\begin{array}{l}\text { The CLL2-BCG-trial is a prospective, open-label, } \\
\text { multicenter phase-II-trial }\end{array}$ & II & NCT02445131 \\
\hline & & & & $\begin{array}{l}\text { To evaluate a combination of drugs called Ofatu- } \\
\text { mumab and CAL-101 as a possible treatment for } \\
\text { CLL and SLL }\end{array}$ & II & NCT02135133 \\
\hline & & & & $\begin{array}{l}\text { To determine the preliminary efficacy and safety of } \\
\text { the combination of tirabrutinib and CAL-101 with } \\
\text { obinutuzumab in adults with R/R CLL }\end{array}$ & II & NCT02968563 \\
\hline & & & IPI-145 & $\begin{array}{l}\text { To study IPI-145 and Venetoclax in subjects with } \\
\text { R/R CLL/SLL or iNHL who have not previously } \\
\text { received a Bcl-2 or PI3K Inhibitor }\end{array}$ & I & NCT02640833 \\
\hline & & & & $\begin{array}{l}\text { To examine the efficacy of IPI- } 145 \text { monotherapy } v s \text {. } \\
\text { ofatumumab monotherapy in subjects with R/R } \\
\text { CLL/SLL }\end{array}$ & III & NCT02004522 \\
\hline & & & & $\begin{array}{l}\text { To examine the efficacy of IPI- } 145 \text { monotherapy or } \\
\text { ofatumumab monotherapy in subjects with CLL/ } \\
\text { SLL who experienced disease progression after } \\
\text { treatment with IPI-145 or ofatumumab in study } \\
\text { IPI-145-07 }\end{array}$ & III & NCT02049515 \\
\hline & & & & $\begin{array}{l}\text { To study IPI-145 in patients with CLL/SLL who } \\
\text { have previously been treated with ibrutinib or } \\
\text { another BTK Inhibitor and R/R to such therapy or } \\
\text { discontinued such therapy due to toxicity }\end{array}$ & II & NCT03370185 \\
\hline & & & & $\begin{array}{l}\text { To test safety, PK and PD of IPI-145 in combina- } \\
\text { tion with obinutuzumab in patients with CLL/SLL } \\
\text { previously treated with a BTKi }\end{array}$ & I & NCT02292225 \\
\hline & & & TGR-1202 & $\begin{array}{l}\text { TGR-1202 may stop cancer cells from growing and } \\
\text { this drug may help to kill cancer cells when cou- } \\
\text { pled with ibrutinib }\end{array}$ & I & NCT02268851 \\
\hline & & & & 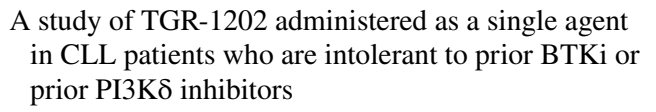 & II & NCT02742090 \\
\hline & MCL & $I S$ & INCB050465 & $\begin{array}{l}\text { Evaluating efficacy and safety of } 2 \text { INCB } 050465 \\
\text { treatment regimens in subjects with R/R MCL } \\
\text { treated either with or without a BTKi }\end{array}$ & II & NCT03235544 \\
\hline & MZL & Pan- & BAY80-6946 & $\begin{array}{l}\text { To test the toxicity and efficacy of BAY 80-6946 in } \\
\text { combination with Rituximab in patients with newly } \\
\text { diagnosed or relapsed MZL }\end{array}$ & II & NCT03474744 \\
\hline & & $I S$ & INCB050465 & $\begin{array}{l}\text { To study INCB050465 in subjects with R/R MZL } \\
\text { with or without prior exposure to CITADEL-204 }\end{array}$ & II & NCT03144674 \\
\hline
\end{tabular}


Table 2 (continued)

\begin{tabular}{|c|c|c|c|c|c|c|}
\hline \multirow[t]{2}{*}{ System } & \multirow[t]{2}{*}{ Cancer } & \multirow[t]{2}{*}{ Subunit } & \multirow[t]{2}{*}{ Inhibitors } & \multirow[t]{2}{*}{ Characteristic } & \multicolumn{2}{|c|}{ Clinical trials } \\
\hline & & & & & Phase & Gov identifier \\
\hline & \multirow[t]{5}{*}{ DLBCL } & \multirow[t]{2}{*}{ Pan- } & \multirow[t]{2}{*}{ BAY80-6946 } & $\begin{array}{l}\text { To study how well BAY } 80-6946 \text { hydrochloride } \\
\text { and nivolumab work in treating patients with R/R } \\
\text { DLBCL or PMLBC }\end{array}$ & II & NCT03484819 \\
\hline & & & & $\begin{array}{l}\text { To assess efficacy of BAY80-6946 in R/R DLBCL } \\
\text { patients and the relationship between efficacy and a } \\
\text { predictive biomarker }\end{array}$ & II & NCT02391116 \\
\hline & & \multirow[t]{2}{*}{$I S$} & \multirow[t]{2}{*}{ INCB050465 } & $\begin{array}{l}\text { To assess the safety and efficacy of INCB050465 in } \\
\text { subjects with R/R DLBCL }\end{array}$ & II & NCT02998476 \\
\hline & & & & $\begin{array}{l}\text { To evaluate the safety and tolerability of } \\
\text { INCB053914 in combination with INCB050465 in } \\
\text { R/R DLBCL }\end{array}$ & I & NCT03688152 \\
\hline & & Dual & CUDC-907 & $\begin{array}{l}\text { To evaluate the efficacy and safety of CUDC- } 907 \text { in } \\
\text { subjects } 18 \text { years and older with R/R MYC-altered } \\
\text { DLBCL }\end{array}$ & II & NCT02674750 \\
\hline & PCNSL & Pan- & BAY80-6946 & $\begin{array}{l}\text { To test the safety of combined use of the study drugs, } \\
\text { BAY80-6946 and ibrutinib, in people with PCNSL }\end{array}$ & I/ II & NCT03581942 \\
\hline & MM & $I S$ & BYL719 & $\begin{array}{l}\text { To estimate the MTD and/or RP2D of the combina- } \\
\text { tion of LGH447 and BYL719 administered orally } \\
\text { to adult patients with R/R MM }\end{array}$ & I & NCT02144038 \\
\hline & \multirow[t]{11}{*}{ Leukemia } & Pan- & BKM120 & $\begin{array}{l}\text { To find the MTD of BKM120 that can be given to } \\
\text { patients with R/R leukemia }\end{array}$ & I & NCT01396499 \\
\hline & & \multirow[t]{10}{*}{$I S$} & \multirow[t]{10}{*}{ CAL-101 } & $\begin{array}{l}\text { To provide CAL-101 to individuals with relapsed, } \\
\text { previously treated CLL who have limited treatment } \\
\text { options }\end{array}$ & & NCT02136511 \\
\hline & & & & $\begin{array}{l}\text { To evaluate the effect of the addition of CAL-101 to } \\
\text { bendamustine + rituximab on PFS in participants } \\
\text { with previously treated CLL }\end{array}$ & III & NCT01569295 \\
\hline & & & & $\begin{array}{l}\text { To evaluate the effect of idelalisib in combination } \\
\text { with rituximab on the onset, magnitude, and dura- } \\
\text { tion of tumor control in participants previously } \\
\text { treated for CLL }\end{array}$ & III & NCT01539512 \\
\hline & & & & $\begin{array}{l}\text { To evaluate the effectiveness of CAL-101 and rituxi- } \\
\text { mab in adults with CLL in a real world setting }\end{array}$ & & NCT03582098 \\
\hline & & & & $\begin{array}{l}\text { Obtaining more in-depth information on how } \\
\text { patients with CLL treated with CAL-101 and } \\
\text { rituximab react to treatment }\end{array}$ & & NCT03545035 \\
\hline & & & & $\begin{array}{l}\text { To study how well pembrolizumab alone or with } \\
\text { CAL-101 or ibrutinib works in treating patients } \\
\text { with CLL or other iB-NHL }\end{array}$ & II & NCT02332980 \\
\hline & & & & $\begin{array}{l}\text { To evaluate efficacy, safety, tolerability and PD of } \\
\text { entospletinib and CAL-101 in patients with CLL, } \\
\text { FL, MCL, DLBCL, or iB-NHL }\end{array}$ & II & NCT01796470 \\
\hline & & & & $\begin{array}{l}\text { To confirm the hypothesis that CAL-101 may repre- } \\
\text { sent a new therapeutic alternative for patients with } \\
\text { ALL in a set of particularly complex scenarios: } \\
\text { relapsed, refractory to conventional treatments, and } \\
\text { old age }\end{array}$ & $\mathrm{I} / \mathrm{II}$ & NCT03742323 \\
\hline & & & & $\begin{array}{l}\text { To investigate the safety and clinical activity of } \\
\text { CAL-101 in combination with chemotherapeutic } \\
\text { agents, immunomodulatory agents and anti-CD20 } \\
\text { mAb in subjects with R/R iNHL, MCL or CLL }\end{array}$ & I & NCT01088048 \\
\hline & & & & $\begin{array}{l}\text { To investigate the safety, PK, PD, and clinical } \\
\text { activity of CAL-101 in patients with select, R/R } \\
\text { Hematologic Malignancies }\end{array}$ & I & NCT00710528 \\
\hline
\end{tabular}


Table 2 (continued)

\begin{tabular}{|c|c|c|c|c|c|c|}
\hline \multirow[t]{2}{*}{ System } & \multirow[t]{2}{*}{ Cancer } & \multirow[t]{2}{*}{ Subunit } & \multirow[t]{2}{*}{ Inhibitors } & \multirow[t]{2}{*}{ Characteristic } & \multicolumn{2}{|c|}{ Clinical trials } \\
\hline & & & & & Phase & Gov identifier \\
\hline & & & & $\begin{array}{l}\text { To determine how well the test can be used to select } \\
\text { personalized kinase inhibitor therapy in combi- } \\
\text { nation with standard chemotherapy in treating } \\
\text { patients with newly diagnosed AML and ALL }\end{array}$ & I & NCT02779283 \\
\hline & & & YY-20394 & $\begin{array}{l}\text { To assess the tolerability, PK and efficacy of } \\
\text { YY-20394 in patients with relapse or refractory B } \\
\text { cell malignant hematological tumor }\end{array}$ & I & NCT03757000 \\
\hline & & Dual & BEZ235 & $\begin{array}{l}\text { To establish the MTD and the RP2D of BEZ235 } \\
\text { when administered twice daily as a single agent in } \\
\text { patients with R/R acute leukemia }\end{array}$ & I & NCT01756118 \\
\hline & & & PKI-587 & $\begin{array}{l}\text { Phase II open-label single-arm prospective multicen- } \\
\text { tric clinical trial of PKI-587 delivered by intrave- } \\
\text { nous route }\end{array}$ & II & NCT02438761 \\
\hline \multirow[t]{2}{*}{ Bone and soft tissue } & OS or EWS & Pan- & BAY80-6946 & $\begin{array}{l}\text { To investigate safe, feasible and beneficial of } \\
\text { BAY80-6946 in pediatric patients with recurrent or } \\
\text { refractory OS, EWS or lymphoma }\end{array}$ & $\mathrm{I} / \mathrm{II}$ & NCT03458728 \\
\hline & & Dual & LY3023414 & $\begin{array}{l}\text { To study how well LY3023414 works in treating } \\
\text { patients with recurrent OS, EWS or NHL }\end{array}$ & II & NCT03213678 \\
\hline \multirow[t]{3}{*}{ Skin } & Melanoma & Pan- & BKM120 & $\begin{array}{l}\text { Trial of BKM } 120 \text { in patients with metastatic mela- } \\
\text { noma with brain metastases who are not eligible } \\
\text { for surgery or radiosurgery }\end{array}$ & II & NCT02452294 \\
\hline & & & PX-866 & $\begin{array}{l}\text { Phase } 1 / 2 \text { study of PX- } 866 \text { combined with Vemu- } \\
\text { rafenib in patients with } B R A F \text {-mutant cancer } \\
\text { including advanced melanoma }\end{array}$ & $\mathrm{I} / \mathrm{II}$ & NCT01616199 \\
\hline & & $I S$ & GSK2636771 & $\begin{array}{l}\text { To learn if GSK2636771 given in combination with } \\
\text { pembrolizumab can help to control the disease in } \\
\text { patients with refractory metastatic melanoma }\end{array}$ & $\mathrm{I} / \mathrm{II}$ & NCT03131908 \\
\hline
\end{tabular}

$A I$ aromatase inhibitor, $A L L$ acute lymphoblastic leukemia, $A M L$ acute myeloid leukemia, $B C$ breast cancer, $B C L$ B-cell lymphoma, $B D$ best dose, $B L C A$ bladder cancer, $B T K i$ BTK inhibitors, $C H L$ classical Hodgkin lymphoma, $C L L / S L L$ chronic lymphocytic leukemia or small lymphocytic lymphoma, $C R C$ colorectal carcinoma, $C R P C$ Castration-Resistant Prostate Cancer, $D B R$ duvelisib in combination with bendamustine and rituximab, $D L T$ dose limiting toxicity, $E C$ endometrial cancer, ESCC esophageal squamous cell carcinoma, EWS Ewing's sarcoma, $F L$ follicular lymphoma, FTC fallopian tube carcinoma, GBM Glioblastoma multiforme, GC gastric cancer, GIST gastrointestinal stromal tumor, $H C C$ hepatocellular carcinoma, $H L$ Hodgkin's lymphoma, HNSCC head-and-neck squamous cell carcinoma, HR hormone receptor, $H S C T$ hematopoietic stem cell transplant, $i B-N H L$ indolent B cell non-Hodgkin's lymphoma, $i N H L$ indolent non-Hodgkin's lymphoma, $I S$ isoform-selective, $I V$ intravenous, $K C$ kidney cancer, $M B C$ metastatic Breast Cancer, $M B M$ medulloblastoma, $M C L$ mantle cell lymphoma, $M M$ multiple myeloma, $M R D$ maximum recommended dose, MTD maximum tolerated dose, mTORi rapamycin inhibitor, $M Z L$ marginal zone lymphoma, NHL non-Hodgkin's lymphoma, $N S C L C$ non-small cell lung cancer, $N K / T C L \mathrm{NK} / \mathrm{T}$ cell lymphomas, $O C$ ovarian cancer, $O R R$ objective response rate, $O S$ osteosarcoma, $P B R$ placebo in combination with bendamustine and rituximab, $P C$ pancreatic cancer, $P C a$ prostate cancer, $P C N S L$ primary central nervous system lymphoma, $P D$ pharmacodynamics, $P D A C$ pancreatic ductal adenocarcinoma, $P F S$ progression-free survival, $P K$ pharmacokinetics, $P M L B C L$ primary mediastinal large B-cell lymphoma, $P N E T$ s pancreatic neuroendocine neoplasms, $P O$ pharmacokinetics of oral, $P T C L$ peripheral T-cell lymphoma, $R C C$ renal cell cancer, $R I T$ radioimmunotherapy, $R P 2 D$ recommended phase 2 dose, $R / R$ relapsed and/ or refractory, $S C C H N$ squamous cell carcinoma of the head and neck, $S C L C$ small cell lung cancer, $S E$ side effects, $T C$ thyroid cancers, $T C L$ T-cell lymphoma, $T N B C$ triple negative breast cancer, $U M$ uveal melanoma

terminated clinical trial (NCT03002623) besides the clinical trial of BKM120 in patients with advanced or metastatic differentiated TCs (NCT01830504, Table 2).

\section{Characterization of the PI3K/AKT pathway in the respiratory system tumor}

The respiratory system tumors are composed of the upper respiratory tract tumors, such as nasopharyngeal carcinoma (NPC) and laryngeal cancer, and the lower respiratory tract tumors, which mainly refer to LC. Compared to the NPC and laryngeal cancer, LC is witnessed as the gender-free and world-wide cancer with the highest morbidity (11.6\%) and mortality (18.4\%, Table 1$)$.

LC is classified into two categories: small cell lung cancer (SCLC) and non-small cell lung cancer (NSCLC) including three subtypes: adenocarcinoma (ADC), squamous cell carcinoma (SCC) and large cell carcinoma (LCC) [65]. In the light of the fact that genetic alterations of PIK3CA (3\% vs. $17 \%)$, PIK3RI (2\% vs. $1.8 \%$ ), PIK3R2 (1.5\% vs. $1.6 \%$ ), 
AKT1 (0.5\% vs. $2.1 \%), A K T 2$ (1.5\% vs. $3 \%)$ and PTEN (8\% vs. 6\%) are observed in SCLC and NSCLC respectively (Table 1), the studies of treatment strategies of LC targeting PI3K/AKT pathway are in full swing. Apart from those widely recognized alterations, such as $E G F R$ and $K R A S$ gene mutations, MET amplification, EML4-ALK rearrangements in NSCLC, somatic mutations and amplification in PIK3CA are described in $3-10 \%$ vs. $35 \%$ of SCC and $0-2.7 \%$ vs. $7 \%$ of ADC respectively [66]. What's more, the expression of PIK3IP1, a negative regulator of PI3K, which can combine the 110 catalytic subunit of PI3K heterodimers to inhibits the activity of PI3K catalytic, is significantly lower in ADC and other tumors tissues [67]. ROCK1, GPX1, PAX6-ZEB2 axis, miR-93 and -496, as well as LINC00665 participate in regulation of the growth, migration, tumorigenesis or chemoresistance of NSCLC through PI3K/AKT pathway [68-73]. Furthermore, IGF- 1 activates PI3K/AKT/ $\beta$-catenin axis, which promotes the symmetric cell division of lung CSC and expands CSC pool, to maintain tumorigenesis [74, 75]. Interestingly, GRP78 plays the same role in radiation resistance and survival of cells in NSCLC by activating AKT1 as in GBM [31]. Currently, the potential of PI3K/AKT inhibitors has been clinically evaluated in a considerable number of studies (Tables 2 and 3) with NSCLC patients. On the other hand, MCAM and EPHA3 mediate chemoresistance in SCLC via the PI3K/AKT pathway [76, 77]. Whether combining daily BKM120 with cisplatin and etoposide was safe and effective in extensive stage SCLC patients had been attempted in a completed clinical trial (NCT02194049, Table 3).

NPC is a unique cancer prevalent in South-East Asia with strong etiological association with Epstein-Barr virus (EBV) exposure [78]. As expected, NPC has a relatively lower mutational burdens with PIK3CA mutations of $1.8 \%$ (Table 1), however, there are still numerous of researches involved in PI3K/AKT pathway in NPC. Not only is hyperactivation of PI3K/AKT pathway in relation to NPC progression and prognosis [79], but FOXO1, CHL1, PNUTS, VPS33B interacts with NESG1, RBM3, ARHGAP42 and LncRNA ZFAS1 also display their influence on the proliferation, growth, invasion, metastasis, EMT, chemosensitivity or radio-resistance of NPC cells via PI3K/AKT pathway [80-86]. Moreover, miR-205-5p induces EMT by targeting PTEN via PI3K/AKT pathway in cisplatin-resistant NPC cells [87].

Typically presenting as a form of squamous cell carcinoma, laryngeal cancer is one of common malignancies in the head and neck, which is partly associated with human papillomavirus (HPV) [78, 88, 89]. A series of studies show the mutational events of PI3K pathway (30.5\%) in 151 head and neck squamous cell carcinomas (HNSCCs) containing 29 laryngeal squamous cell carcinomas (LSCCs), particularly PIK3CA mutations of $12.6 \%$ [90-92]. Furthermore, profiling 279 HNSCCs containing 72 LSCCs, alteration events of PIK3CA (34\% vs. 56\%), PIK3RI (1 vs. 3\%) and PTEN (12\% vs. $6 \%)$ are displayed in 243 HPV (-) and 36 HPV (+) HNSCCs respectively [93]. Additionally, MMP2/3, MEOX2, miR-145 and -138 regulate the growth, apoptosis or migration of LSCC cells by targeting the PI3K/AKT pathway [94-97].

Herein, clinical trials of BKM120 (Table 2) in NPC and LSCC patients may provide the feasibility of new treatment strategies. Even more, the safety and efficacy of AKT inhibitor MK2206 in NPC patients had been evaluated in a completed clinical trial (Table 3 ).

\section{Deregulation of the PI3K/AKT pathway in digestive system tumors}

It's well established that the global health status is jeopardized by digestive system tumors, and the incidence and mortality rate of main digestive system tumors including esophageal cancer (ESCA), GC, colorectal cancer (CRC), as well as hepatocellular, gallbladder and pancreatic cancer (PC) are listed in Table 1.

Esophageal squamous cell carcinoma (ESCC) is the most frequent ESCA subtype internationally. In general, the genetic alterations of PIK3CA (24\%), and PTEN (7\%) are observed in ESCA (Table 1), especially the somatic mutations of PIK3CA (7.2\% vs $12.5 \%$ ), PIK $3 C 2 A$ ( $0.7 \%$ vs. $0), P I K 3 C G(2.9 \%$ vs. $4.2 \%)$ and $P I K 3 C 2 G$ (0 vs. $37.5 \%)$ are observed respectively in 139 paired ESCC cases and 24 cell lines [98]. Even more, PIK3CA mutations are frequent in ESCC associated with chagasic megaesophagus and are associated with a worse patient outcome [99]. HERG1, LSD1, CEP55, CACNA2D3, CircVRK1 and lncRNA GAS5 affect the proliferation, migration, invasion or radioresistance of ESCC cells via the PI3K/AKT pathway [100-105]. After all, a limited number of clinical trials of PI3K inhibitors BYL719 and BKM120 in ESCC patients may bring efficacious therapeutic proposals (Table 2).

The incidence (5.7\%) of GC, in which gastric adenocarcinoma (GAC) is the dominant subtype, has continued to decline worldwide due to the $H$ pylori treatment [106], but the mortality rate $(8.2 \%)$ remains the second most common cause of cancer death worldwide (Table 1). As shown in Table 1, the overall genetic alterations of PI3K/AKT pathway are observed with PIK3CA (17\%) and PTEN (11\%) in GC. But one research reveals that PI3K/AKT pathway genetic mutations are found in $69(16 \%)$ of the $431 \mathrm{GC}$ patients including PIK3CA (13.2\%) and PTEN (4.0\%), as well as PIK3CA amplifications are found in 206 (47.8\%) of the patients [107]. Another research shows that advanced GC patient have more frequency of PIK3CA mutations in codon 545 than in codon 1047 [108]. A large number of researches confirm that besides NETO2, UFM1, STIL, LEMD1, SPP1 
Table 3 Clinical trial of AKT Inhibitors in cancers (as of December 2019) (https://clinicaltrials.gov)

\begin{tabular}{|c|c|c|c|c|c|c|}
\hline \multirow[t]{2}{*}{ System } & \multirow[t]{2}{*}{ Cancer } & \multirow[t]{2}{*}{ Subunit } & \multirow[t]{2}{*}{ Inhibitors } & \multirow[t]{2}{*}{ Characteristic } & \multicolumn{2}{|c|}{ Clinical trials } \\
\hline & & & & & Phase & Gov identifier \\
\hline \multirow[t]{2}{*}{ Brain and central nervous } & GBM & Allosteric & Perifosine & $\begin{array}{l}30 \text { adults with recurrent GBM were treated with a } \\
\text { loading dose of } 600 \mathrm{mg} \text { Perifosine followed by } \\
100 \mathrm{mg} \text { daily until either disease progression or } \\
\text { intolerable toxicity. Perifosine is tolerable but } \\
\text { ineffective as monotherapy for GBM. Preclinical } \\
\text { data suggests synergistic effects of Perifosine in } \\
\text { combination with other approaches, and further } \\
\text { study is ongoing }\end{array}$ & II & $(24)$ \\
\hline & UM & ATP-comp & GSK2141795 & $\begin{array}{l}\text { Trametinib and GSK2141795 may stop the growth } \\
\text { of tumor cells by blocking some of the enzymes } \\
\text { needed for cell growth. It is not yet known } \\
\text { whether trametinib is more effective with or } \\
\text { without GSK2141795 in treating patients with } \\
\text { metastatic UM }\end{array}$ & II & NCT01979523 \\
\hline \multirow[t]{4}{*}{ Respiratory } & NSCLC & Allosteric & MK2206 & $\begin{array}{l}\text { MK2206 and erlotinib hydrochloride may stop the } \\
\text { growth of tumor cells by blocking some of the } \\
\text { enzymes needed for cell growth }\end{array}$ & II & NCT01294306 \\
\hline & & & & $\begin{array}{l}\text { Combination of MK2206 and gefitinib for the } \\
\text { treatment of patients with NCLC who have failed } \\
\text { prior chemotherapy and an EGFR-TKI }\end{array}$ & I & NCT01147211 \\
\hline & & & & $\begin{array}{l}\text { Whether it helps to control NSCLC with } \\
\text { drug combinations (Erlotinib + MK2206 or } \\
\text { AZD6244+MK2206) and the safety of these } \\
\text { drug combinations remains to be studied }\end{array}$ & II & NCT01248247 \\
\hline & & & Perifosine & $\begin{array}{l}\text { To determine the MTD of perifosine that can be } \\
\text { administered to people without gastrointestinal } \\
\text { toxicity and obtain preliminary information on } \\
\text { the response rate of perifosine in NSCLC }\end{array}$ & $\mathrm{I} / \mathrm{II}$ & NCT00399789 \\
\hline \multirow[t]{4}{*}{ Digestive } & GC & Allosteric & MK2206 & $\begin{array}{l}\text { To study how well MK2206 works in treating } \\
\text { patients with advanced GC or GEJC }\end{array}$ & II & NCT01260701 \\
\hline & & & & $\begin{array}{l}\text { To study the side effects and BD of MK2206 and } \\
\text { lapatinib ditosylate when given together with } \\
\text { trastuzumab in treating patients with locally } \\
\text { advanced or metastatic GC, or GEC that cannot } \\
\text { be removed by surgery }\end{array}$ & I & NCT01705340 \\
\hline & & ATP-comp & GSK2110183 & $\begin{array}{l}\text { To determine the MTD and RP2D for the combi- } \\
\text { nation of GSK2110183 and paclitaxel in subjects } \\
\text { with recurrent HER2-GC, and further assess } \\
\text { safety and preliminary efficacy of combination at } \\
\text { the RP2D }\end{array}$ & I & NCT02240212 \\
\hline & & & GDC-0068 & $\begin{array}{l}\text { To evaluate the efficacy of GDC-0068 in combina- } \\
\text { tion with oxaliplatin, } 5 \text {-fluorouracil, and leucov- } \\
\text { orin chemotherapy in participants with advanced } \\
\text { or metastatic GC or GEJC }\end{array}$ & II & NCT01896531 \\
\hline
\end{tabular}


Table 3 (continued)

\begin{tabular}{|c|c|c|c|c|c|c|}
\hline \multirow[t]{2}{*}{ System } & \multirow[t]{2}{*}{ Cancer } & \multirow[t]{2}{*}{ Subunit } & \multirow[t]{2}{*}{ Inhibitors } & \multirow[t]{2}{*}{ Characteristic } & \multicolumn{2}{|c|}{ Clinical trials } \\
\hline & & & & & Phase & Gov identifier \\
\hline & $\mathrm{CRC}$ & Allosteric & MK2206 & $\begin{array}{l}\text { To evaluate the safety and effectiveness of } \\
\text { MK-2206 and AZD6244 in individuals with } \\
\text { advanced CRC that has not responded to stand- } \\
\text { ard treatments }\end{array}$ & II & NCT01333475 \\
\hline & & & & $\begin{array}{l}\text { To study how well MK2206 works in treating } \\
\text { patients with previously treated CRC that has } \\
\text { spread from the primary site to other places in } \\
\text { the body or nearby tissue or lymph nodes and } \\
\text { cannot be removed by surgery }\end{array}$ & II & NCT01802320 \\
\hline & & & & $\begin{array}{l}\text { MK2206 is being tested in a subgroup of patients } \\
\text { with CRC whose tumors have changes in cer- } \\
\text { tain genes that may make them more likely to } \\
\text { respond to MK2206 }\end{array}$ & II & NCT01186705 \\
\hline & & ATP-comp & GSK2141795 & $\begin{array}{l}\text { GSK2141795 given together with dabrafenib and } \\
\text { trametinib may be a better treatment for cancer }\end{array}$ & $\mathrm{I} / \mathrm{II}$ & NCT01902173 \\
\hline & $\mathrm{HCC}$ & Allosteric & MK2206 & $\begin{array}{l}\text { MK2206 may stop the growth of tumor cells by } \\
\text { blocking some of the enzymes needed for cell } \\
\text { growth }\end{array}$ & II & NCT01239355 \\
\hline & & & & $\begin{array}{l}\text { How well MK2206 works in treating patients with } \\
\text { advanced or non-resectable HCC }\end{array}$ & II & NCT01425879 \\
\hline & GBC & Allosteric & MK2206 & $\begin{array}{l}\text { To study how well selumetinib and MK2206 work } \\
\text { in treating patients with refractory or advanced } \\
\text { GBC that cannot be removed by surgery }\end{array}$ & II & NCT01859182 \\
\hline & & & & $\begin{array}{l}\text { How well MK2206 works in treating patients with } \\
\text { Stage IV GBC }\end{array}$ & II & NCT01425879 \\
\hline & $\mathrm{PC}$ & Allosteric & MK2206 & $\begin{array}{l}\text { Selumetinib and MK2206 may stop the growth of } \\
\text { tumor cells. To find if selumetinib and MK2206 } \\
\text { are more effective than oxaliplatin and fluoroura- } \\
\text { cil in treating patients with metastatic PC }\end{array}$ & II & NCT01658943 \\
\hline \multirow[t]{6}{*}{ Female Reproductive } & $\mathrm{BC}$ & Allosteric & MK2206 & $\begin{array}{l}\text { To study how well MK2206 works in treating } \\
\text { patients with BC that has spread to other places } \\
\text { in the body and usually cannot be cured or con- } \\
\text { trolled with treatment }\end{array}$ & II & NCT01277757 \\
\hline & & & & $\begin{array}{l}\text { To study the side effects and BD of MK2206 when } \\
\text { given together with paclitaxel and to see how } \\
\text { well they work in treating patients with MBC }\end{array}$ & I & NCT01263145 \\
\hline & & & & $\begin{array}{l}\text { Giving MK2206 together with anastrozole, fulves- } \\
\text { trant may kill more tumor cells }\end{array}$ & I & NCT01344031 \\
\hline & & & & $\begin{array}{l}\text { Giving MK-2206, anastrozole, and goserelin } \\
\text { acetate together may kill more tumor cells }\end{array}$ & II & NCT01776008 \\
\hline & & & & $\begin{array}{l}\text { MK2206 may stop the growth of MBC cells by } \\
\text { blocking some of the enzymes needed for cell } \\
\text { growth when combined with Lapatinib ditosylate }\end{array}$ & I & NCT01281163 \\
\hline & & & & $\begin{array}{l}\text { To study the side effects and BD of MK2206 and } \\
\text { lapatinib ditosylate when given together with } \\
\text { trastuzumab in treating patients with locally } \\
\text { advanced or metastatic HER } 2+\text { BC that cannot } \\
\text { be removed by surgery }\end{array}$ & I & NCT01705340 \\
\hline
\end{tabular}


Table 3 (continued)

\begin{tabular}{|c|c|c|c|c|c|c|}
\hline \multirow[t]{2}{*}{ System } & \multirow[t]{2}{*}{ Cancer } & \multirow[t]{2}{*}{ Subunit } & \multirow[t]{2}{*}{ Inhibitors } & \multirow[t]{2}{*}{ Characteristic } & \multicolumn{2}{|c|}{ Clinical trials } \\
\hline & & & & & Phase & Gov identifier \\
\hline & & ATP-comp & GSK2141795 & $\begin{array}{l}\text { Trametinib and GSK2141795 may stop the growth } \\
\text { of tumor cells by blocking some of the enzymes } \\
\text { needed for cell growth }\end{array}$ & II & NCT01964924 \\
\hline & & & AZD5363 & $\begin{array}{l}\text { AZD5363 may stop the growth of tumor cells } \\
\text { by blocking some of the enzymes needed for } \\
\text { advanced BC cell growth }\end{array}$ & I & NCT02077569 \\
\hline & & & & $\begin{array}{l}\text { AZD5363 in combination with paclitaxel can be } \\
\text { used in triple negative advanced or MBC }\end{array}$ & II & NCT02423603 \\
\hline & & & GDC-0068 & $\begin{array}{l}\text { Combine GDC- } 0068 \text { with paclitaxel chemotherapy } \\
\text { to treat BC }\end{array}$ & II & NCT02301988 \\
\hline & & Indirect $^{\mathrm{a}}$ & ONC201 & $\begin{array}{l}\text { ONC201 is able to target tumor cells to get rid } \\
\text { of them without affecting normal cells. Giving } \\
\text { ONC201 and a MR diet may work better in treat- } \\
\text { ing participants with BC }\end{array}$ & I & NCT03733119 \\
\hline & $\mathrm{OC}$ & Allosteric & Perifosine & $\begin{array}{l}\text { Perifosine may help docetaxel be more effective in } \\
\text { causing cancer cells to die }\end{array}$ & I & NCT00431054 \\
\hline & & & Triciribine & $\begin{array}{l}\text { Investigate the safety and tolerability, and deter- } \\
\text { mine the maximum tolerated dose of triciribine } \\
\text { when combined with carboplatin in women with } \\
\text { platinum-resistant, recurrent or persistent OC }\end{array}$ & $\mathrm{I} / \mathrm{II}$ & NCT01690468 \\
\hline & & & MK2206 & $\begin{array}{l}\text { How effective MK2206 is in treating OC with } \\
\text { mutations in PI3K/AKT or low levels of PTEN }\end{array}$ & II & NCT01283035 \\
\hline & & ATP-comp & AZD5363 & $\begin{array}{l}\text { Olaparib and AZD5363 may stop the growth of } \\
\text { tumor cells by blocking some of the enzymes } \\
\text { needed for cell growth }\end{array}$ & $\mathrm{I} / \mathrm{II}$ & NCT02208375 \\
\hline & & & GSK2110183 & $\begin{array}{l}\text { GSK2110183 in combination with carboplatin } \\
\text { and paclitaxel for the treatment of recurrent } \\
\text { platinum-resistant OC }\end{array}$ & $\mathrm{I} / \mathrm{II}$ & NCT01653912 \\
\hline & & & GSK2141795 & $\begin{array}{l}\text { GSK2141795 given together with dabrafenib and } \\
\text { trametinib may be a better treatment for cancer }\end{array}$ & $\mathrm{I} / \mathrm{II}$ & NCT01902173 \\
\hline & & & & $\begin{array}{l}\text { Investigate the PK and PD of GSK } 2141795 \text { by } 18 \mathrm{~F} \\
\text { FDG PET Analysis }\end{array}$ & I & NCT01266954 \\
\hline & FTC & Allosteric & MK2206 & $\begin{array}{l}\text { How effective MK- } 2206 \text { is in treating FTC where } \\
\text { there are mutations in PI } 3 K \text { or } A K T \text { or low levels } \\
\text { of PTEN }\end{array}$ & II & NCT01283035 \\
\hline & & ATP-comp & AZD5363 & $\begin{array}{l}\text { Olaparib and AZD5363 may stop the growth of } \\
\text { tumor cells by blocking some of the enzymes } \\
\text { needed for cell growth }\end{array}$ & $\mathrm{I} / \mathrm{II}$ & NCT02208375 \\
\hline & EC & ATP-comp & ARQ 092 & $\begin{array}{l}\text { Whether ARQ } 092 \text { and anastrozole can treat EC } \\
\text { remains to be studied }\end{array}$ & $\mathrm{I} / \mathrm{II}$ & NCT02476955 \\
\hline & & & GSK2141795 & $\begin{array}{l}\text { Trametinib and GSK } 2141795 \text { may stop the growth } \\
\text { of tumor cells. It is not yet known whether } \\
\text { trametinib is a more effective treatment for EC } \\
\text { when given with or without GSK } 2141795\end{array}$ & I & NCT01935973 \\
\hline & & Allosteric & MK2206 & $\begin{array}{l}\text { MK2206 may stop the growth of EC cells by } \\
\text { blocking some of the enzymes needed for cell } \\
\text { growth }\end{array}$ & II & NCT01307631 \\
\hline & $\mathrm{CC}$ & ATP-comp & GSK2141795 & $\begin{array}{l}\text { To evaluate the combination of GSK1120212 and } \\
\text { GSK2141795 as a possible treatment for recur- } \\
\text { rent or persistent CC }\end{array}$ & II & NCT01958112 \\
\hline
\end{tabular}


Table 3 (continued)

\begin{tabular}{|c|c|c|c|c|c|c|}
\hline \multirow[t]{2}{*}{ System } & \multirow[t]{2}{*}{ Cancer } & \multirow[t]{2}{*}{ Subunit } & \multirow[t]{2}{*}{ Inhibitors } & \multirow[t]{2}{*}{ Characteristic } & \multicolumn{2}{|c|}{ Clinical trials } \\
\hline & & & & & Phase & Gov identifier \\
\hline \multirow[t]{4}{*}{ Genitourinary } & \multirow[t]{2}{*}{$\mathrm{KC}$} & \multirow[t]{2}{*}{ Allosteric } & \multirow[t]{2}{*}{ MK2206 } & $\begin{array}{l}\text { To study the side effects and the BD of MK2206 } \\
\text { together with hydroxychloroquine in treating } \\
\text { patients with advanced KC }\end{array}$ & I & NCT01480154 \\
\hline & & & & $\begin{array}{l}\text { To study the side effects and how well MK2206 } \\
\text { or everolimus works in treating patients with KC } \\
\text { that does not respond to treatment }\end{array}$ & II & NCT01239342 \\
\hline & \multirow[t]{2}{*}{$\mathrm{PCa}$} & \multirow[t]{2}{*}{ Allosteric } & \multirow[t]{2}{*}{ MK2206 } & $\begin{array}{l}\text { To study the side effects and the BD of MK2206 } \\
\text { together with hydroxychloroquine in treating } \\
\text { patients with advanced PCa }\end{array}$ & I & NCT01480154 \\
\hline & & & & $\begin{array}{l}\text { To study the side effects and BD of dinaciclib and } \\
\text { MK2206 in treating patients with PCa that can- } \\
\text { not be removed by surgery }\end{array}$ & I & NCT01783171 \\
\hline \multirow[t]{13}{*}{ Hematologic } & HM & ATP-comp & GSK2110183 & $\begin{array}{l}\text { To investigate the safety, tolerability, PK, and PD } \\
\text { of GSK2110183 in subjects with any HM }\end{array}$ & $\mathrm{I} / \mathrm{II}$ & NCT00881946 \\
\hline & \multirow[t]{2}{*}{ Lymphoma } & Allosteric & MK2206 & $\begin{array}{l}\text { To study how well MK2206 works in treating } \\
\text { patients with relapsed lymphoma }\end{array}$ & II & NCT01258998 \\
\hline & & ATP-comp & GSK690693 & $\begin{array}{l}\text { To investigate the safety, tolerability, PK, and PD } \\
\text { of GSK690693 given on various schedules in } \\
\text { subjects with solid tumors or lymphoma }\end{array}$ & I & NCT00493818 \\
\hline & NHL & Indirect $^{\mathrm{a}}$ & ONC201 & $\begin{array}{l}\text { ONC201 may stop the growth of cancer cells by } \\
\text { blocking some of the enzymes needed for cell } \\
\text { growth }\end{array}$ & $\mathrm{I} / \mathrm{II}$ & NCT02420795 \\
\hline & DLBCL & Allosteric & MK2206 & $\begin{array}{l}\text { MK2206 may stop the growth of cancer cells by } \\
\text { blocking some of the enzymes needed for cell } \\
\text { growth }\end{array}$ & II & NCT01481129 \\
\hline & \multirow[t]{4}{*}{ MM } & \multirow[t]{3}{*}{ ATP-comp } & GSK2141795 & $\begin{array}{l}\text { Studying how well trametinib and GSK } 2141795 \\
\text { work in treating patients with relapsed/refractory } \\
\text { MM }\end{array}$ & II & NCT01989598 \\
\hline & & & \multirow[t]{2}{*}{ GSK2110183 } & $\begin{array}{l}\text { To evaluate safety, tolerability, PK, PD and clinical } \\
\text { activity of GSK } 2110183 \text { dosed in combination } \\
\text { with bortezomib and dexamethasone in MM sub- } \\
\text { jects who have failed at least one line of systemic } \\
\text { treatment }\end{array}$ & I & NCT01428492 \\
\hline & & & & $\begin{array}{l}\text { To investigate the safety, PK, PD, and clinical } \\
\text { activity of GSK1120212 in combination with } \\
\text { GSK2110183 in MM patients }\end{array}$ & I & NCT01476137 \\
\hline & & Allosteric & KRX-0401 & $\begin{array}{l}\text { To assess the efficacy and safety of KRX-0401, } \\
\text { Bortezomib and Dexamethasone in MM patients }\end{array}$ & III & NCT01002248 \\
\hline & Leukemia & Allosteric & MK2206 & $\begin{array}{l}\text { To study the SE, best way to give, and BD of } \\
\text { MK2206 in treating patients with recurrent or } \\
\text { refractory solid tumors or leukemia }\end{array}$ & I & NCT01231919 \\
\hline & \multirow[t]{2}{*}{ AML } & ATP-comp & GSK2141795 & $\begin{array}{l}\text { To study how well trametinib and GSK } 2141795 \\
\text { work in treating patients with AML }\end{array}$ & II & NCT01907815 \\
\hline & & Allosteric & MK2206 & $\begin{array}{l}\text { Studying how well MK2206 works in treating } \\
\text { patients with relapsed or refractory AML }\end{array}$ & II & NCT01253447 \\
\hline & CLL/SLL & Allosteric & MK2206 & $\begin{array}{l}\text { Giving MK2206 with bendamustine hydrochloride } \\
\text { and rituximab may be an effective treatment for } \\
\text { relapsed CLL/SLL }\end{array}$ & $\mathrm{I} / \mathrm{II}$ & NCT01369849 \\
\hline
\end{tabular}


Table 3 (continued)

\begin{tabular}{|c|c|c|c|c|c|c|}
\hline \multirow[t]{2}{*}{ System } & \multirow[t]{2}{*}{ Cancer } & \multirow[t]{2}{*}{ Subunit } & \multirow[t]{2}{*}{ Inhibitors } & \multirow[t]{2}{*}{ Characteristic } & \multicolumn{2}{|c|}{ Clinical trials } \\
\hline & & & & & Phase & Gov identifier \\
\hline \multirow[t]{3}{*}{ Skin } & \multirow[t]{3}{*}{ Melanoma } & ATP-comp & GSK2141795 & $\begin{array}{l}\text { GSK } 2141795 \text { given together with dabrafenib and } \\
\text { trametinib may be a better treatment for cancer }\end{array}$ & $\mathrm{I} / \mathrm{II}$ & NCT01902173 \\
\hline & & \multirow[t]{2}{*}{ Allosteric } & \multirow[t]{2}{*}{ MK2206 } & $\begin{array}{l}\text { To study the side effects and BD of MK2206 } \\
\text { together with hydroxychloroquine in treating } \\
\text { patients with advanced melanoma }\end{array}$ & I & NCT01480154 \\
\hline & & & & $\begin{array}{l}\text { To study how well selumetinib and MK2206 works } \\
\text { in treating patients with stage III or stage IV } \\
\text { melanoma who failed prior therapy with vemu- } \\
\text { rafenib or dabrafenib }\end{array}$ & II & NCT01519427 \\
\hline $\begin{array}{l}\text { Solid tumors with } \\
\text { PIK3CA/AKT/PTEN } \\
\text { mutations }\end{array}$ & & Allosteric & ARQ 751 & $\begin{array}{l}\text { ARQ } 751 \text { inhibits the abnormalities of AKT } \\
\text { caused by other genes, which prevent or slow } \\
\text { the spread of cancer, in addition to ARQ } 751 \text { in } \\
\text { combination with paclitaxel or fulvestrant may } \\
\text { enhance the effect of monotherapy on PIK3CA/ } \\
\text { AKT/PTEN mutation-driven tumors }\end{array}$ & I & NCT02761694 \\
\hline
\end{tabular}

$A M L$ acute myeloid leukemia, Allosteric Allosteric inhibitor, $A T P$-comp ATP-competitive inhibitor, $B C$ breast cancer, $B D$ best dose, $B L C A$ bladder cancer, $C C$ cervical cancer, $C L L / S L L$ chronic lymphocytic leukemia or small lymphocytic lymphoma,. $C R C$ colorectal carcinoma, $D L B C L$ diffuse large B cell lymphoma, $E C$ endometrial cancer, EGFR-TKI epidermal growth factor receptor tyrosine kinase inhibitor, $F T C$ fallopian tube carcinoma, GBC gallbladder cancer, $G C$ gastric cancer, $G E C$ gastroesophageal cancers, $G E J C$ gastroesophageal junction cancer, $H C C$ hepatocellular carcinoma, $H M$ hematologic malignancies, $K C$ kidney cancer, $M B C$ metastatic breast cancer, $M R$ methionine-restricted, $M T D$ maximum tolerated dose, $M M$ multiple myeloma, $N H L$ non-Hodgkin's lymphoma, $N S C L C$ non-small cell lung cancer, $O C$ ovarian cancer, $P C$ pancreatic cancer, $P C a$ prostate cancer, $P D$ pharmacodynamics, $P F S$ progression-free survival, $P K$ pharmacokinetics, $R P 2 D$ recommended phase 2 dose; SE, side effects; UM, uveal melanoma

${ }^{a}$ Indirect: ONC201 is an AKT/ERK inhibitor

and PRL-3, miR-19a, 21, 34a, 137 and 196b, as well as lncRNA MALAT1, STXBP5-AS1 and PICART1 are involved in modulating biological functions of GC cells via PI3K/AKT pathway [109-122]. A lot of clinical trials of PI3K inhibitors (BKM120, BYL719 and GSK2636771. Table 2) and AKT inhibitors (MK2206, GSK2110183 and GDC-0068. Table 3) in GC patients try to save their lives, especially the patients with advanced or metastatic GC.

Although CRC screening has reduced the incidence and mortality nowadays [123], CRC remains one of the main reasons of tumor-related deaths worldwide (Table 1). The overall genetic alterations of PI3K/AKT pathway in CRC are observed as follows: PIK3CA (22\%), PIK3R1 (5\%), PIK3R2 (2.2\%), AKT1 (1.8\%), AKT2 (2.5\%) and PTEN (8\%, Table 1). Contrary to predictions, PIK3CA mutations do not predict aggressive clinicopathological characteristics in CRC, whereas they are closely associated with KRAS mutations, as well as PIK3CA exon 9 and 20 mutations show different tendencies with respect to $B R A F$ mutation and $M S I$ status [124]. Similar to ADC, the expression of PIK3IP1 is also significantly lower in CRC tissues [67]. CXCL12, NLRC3, Wnt/ $\beta$-catenin target genes including BAMBI, BOP1, CKS2 and NFIL3, as well as miRNA-135b, Linc00659 and CRNDE are associated with the proliferation, invasion or metastasis of CRC cells via PI3K/AKT signaling [125-130]. As shown in Tables 2 and 3, multiple clinical trials of PI3K/
AKT inhibitors in CRC patients try to yield useful inhibitors for treatment [131].

As the most common mesenchymal tumor of the digestive system, gastrointestinal stromal tumors (GISTs) mainly harbor mutually exclusive KIT or PDGFRA mutations, which lead to constitutive activation of the encoded receptor tyrosine kinase (RTK) and activation of downstream pathways including PI3K/AKT pathway [132, 133]. Genetic alterations of PIK3CA and PTEN are observed more frequency in malignant GISTs than in less malignant GISTs in 65 GIST samples with 14/65 overall genetic alterations of PI3K/AKT pathway [134]. It is noted that FASN overexpression often occurs in high-risk and metastatic GISTs, whereas combination therapy with imatinib and C75 targeting FASN has been demonstrated in vitro and vivo to down-regulate the phosphorylation levels of the KIT and PI3K/AKT/mTOR pathway $[135,136]$. MiR-374b modulates proliferation and apoptosis of GIST cells through PI3K/AKT pathway [137]. Combination of imatinib mesylate (IM) and MK2206 provide obviously greater efficacy than treatment with IM or MK2206 alone in vitro and vivo preclinical study of GIST [138]. Furthermore, clinical trials of combination of Imatinib and BKM120 (NCT01468688) or BYL719 (NCT01735968, Table 2) were tested in GIST patients.

Being the third most common cause of cancer death worldwide with the mortality rate of $8.2 \%$, hepatocellular 
cancer (HCC) is a distinct tumor of the digestive system and exhibits a different genetic alteration pattern of PI3K/AKT pathway, such as PIK3CA (3\%), PIK3RI (1.2\%), PIK3R2 (1.5\%), AKT1 (0.7\%), AKT2 (1.1\%) and PTEN (4\%) respectively (Table 1). Similarly, PIK3IP1 also suppresses the development of HCC $[67,139]$. Moreover, APLN, miR-7, $-367,-1296$, and $-3691-5 p$ as well as lncRNA PTTG3P and LINC01133 are associated with the proliferation, invasion, metastasis or EMT of HCC cells via PI3K/AKT pathway [140-146]. A small amount of clinical trials of PI3K inhibitors (SF1126, GSK2636771) and AKT inhibitors (MK2206) in HCC patients may give them an opportunity for relief (Tables 2 and 3 ).

Regarding gallbladder cancer (GBC) is the most common malignancy of the biliary tract, the general genetic abnormalities of PIK3CA (10\%) and PTEN (2.3\%) are found (Table 1), especially the PIK3CA E545K mutation rate (6.15\%) [147]. Due to ErbB2 and ErbB3 mutations at a frequency of 7-8\% in GBC, ErbB2/ErbB3 mutation inducing PD-L1 overexpression can mediate immune escape of tumor cells via PI3K/AKT pathway in vitro [148]. In addition, EIF3d, UBR5, BRD4, TRIM31 and LINC00152 are demonstrated to contribute to cell growth or tumor metastasis of GBC cells via PI3K/AKT pathway [149-153]. Currently, only MK2206 was tested in clinical trials (NCT01859182 and NCT01425879) in GBC patients.

Pancreatic cancer (PC) is a fatal malignancy in the digestive system tumors and takes the first place among asymptomatic cancers (Table 1). Take into consideration that more than $90 \%$ of PC is pancreatic ductal adenocarcinoma (PDAC) with the 5-year overall survival (OS) rate less than 5-10\% [154], novel targeting therapies are in urgent need. In contrast to the well-known genetically inactivated of $P 16$ (90\%), TP53 (75\%), DPC4 (55\%), as well as activated oncogene KRAS (90\%) and Her2 (4-50\%) in PDAC [155-159], the overall genetic aberrations of PI3K/AKT members (PIK3CA, 2.3\% and PTEN 1.9\%, Table 1) are less frequently. Interestingly, pancreatic cell plasticity and cancer initiation induced by Kras is completely dependent on wild-type p1 10 $\alpha$ [160], and PAK4 interacts with p85 $\alpha$ can affect the migration of PDAC cells [161]. Significantly, the mutations of PIK3CG in PDAC are also revealed [156]. EG-VEGF, TMEM158, miR-107, as well as LncRNA ABHD11-AS1, SNHG1 and AB209630 are involved in proliferation, apoptosis, metastasis or carcinogenesis of PDAC cells through PI3K/AKT pathway [162-167]. Plenty of clinical trials of PI3K inhibitors (BKM120, BYL719, GSK2636771, PKI587, BEZ235 and LY3023414. Table 2) and AKT inhibitor (MK2206. Table 3) in PDAC patients may reveal promising therapeutic activities.

\section{Abnormalities of the PI3K/AKT pathway in breast and female reproductive system tumor}

BC, which is Estrogen (ER)-related cancer, is the second common cancer in the world (morbidity of $11.6 \%$ ) but in the first place and the most frequent cause of cancer death (mortality of 6.6\%) among women worldwide (Table 1). Compared to the recognized genetically diverse of Her2 and TOP $2 A$ of $\mathrm{BCs}$, the overall genetic alterations of PI3K/ AKT pathway are not uncommon, especially PIK3CA (37\%) and PTEN (8\%, Table 1). Remarkably, hotspot mutations in $P I K 3 C A$ are frequent in ER+BCs, which account for up to $80 \%$ of BCs, and Her 2 mutations hyperactivate the HER3/ $\mathrm{PI} 3 \mathrm{~K} / \mathrm{AKT} / \mathrm{mTOR}$ axis, leading to anti-ER resistance in ER+BCs. Hence, dual blockade of the Her2 and ER pathways is necessary for the treatment of $\mathrm{ER}+/ \mathrm{Her} 2$ mutant BCs [168]. Moreover, PIK3CA and MAP $3 K 1$ alterations reveal Luminal A status in $\mathrm{ER}+$ metastatic $\mathrm{BC}$ and the patients are likely to clinically benefit from BKM120 [169]. On the other hand, top to $70 \%$ of patients with breast cancer brain metastases (BCBM) show the activated PI3K pathway [170], and GDC-0084 induces apoptosis of PIK3CA-mutant BCBM cells by suppressing activation of AKT and p70 S6 kinase [171]. Additionally, PRLR/Jak2/STAT5 is the main signaling pathway for activation in mammary gland, and PRLR-triggered pro-tumorigenic pathways in BC include the PI3K/AKT pathway [172]. As well, numerous studies have shown that IRS4, CDK12, SPC24, Mfng, Transgelin 2, STX3, SOX4, PAK4, TPX2, MEG3 and miR-21, -93, $-106 \mathrm{~b},-130 \mathrm{~b},-214,-361-5 \mathrm{p},-489,-511,-564$ as well as IncRNA-HOTAIR and MALAT1 regulate tumorigenesis, proliferation, apoptosis, invasion, migration, paclitaxel resistance or anti-Her2 therapy (trastuzumab) resistance of BC cells through PI3K/AKT pathway [173-191]. And then, PI3K/AKT inhibitors have gained wide attentions, and a large number of clinical trials may have provided tremendous promises in the treatment of BC patients (shown in Tables 2 and 3).

Globally, the incidence and mortality rate of ovarian cancer (OC), which is the most frequently fatal cancer in female reproductive tract with a wide-range of pathological subtypes, are $1.6 \%$ and $1.9 \%$ respectively (Table 1 ). Ovarian serous cystadenocarcinoma (OSC), the leading common subtype of epithelial ovarian cancers (EOC) accounting for $90 \%$ of OC, harbors overall genetic alterations of PIK3CA (29\%), PIK3R1 (5\%), PIK3R2 (9\%), AKT1 (5\%), AKT2 (8\%) and PTEN (7\%, Table 1) besides the mutant $p 53$ in highgrade OSC (HGOSC), germline BRCA1 and BRCA2 mutations. Furthermore, another subtype of EOC, ovarian clear cell carcinomas (OCCCs), shows more frequently mutations of PIK3CA (33\%) and PTEN (5\%) in overall 97 OCCC cases, especially mutations of PIK3CA (46\%) in the 28 cases of affinity purified OCCCs and OCCC cell lines [192], than 
the mutation of PIK3CA and PTEN (both <5\%) in HGOSC [193]. Huge amounts of studies have shown YAP, PKG II, SIK2, SERPIND1, miR-15b, -21, -150, -222-3p, -337-3p, $-497,-503$ and -936, as well as LncRNA MALAT1 and JPX modulate proliferation, apoptosis, invasion, migration, angiogenesis, progression, glucose metabolism or drug resistance of OC cells by PI3K/AKT pathway [194-207]. Some clinical trials of PI3K/AKT inhibitors or in combination with chemotherapy drugs listed in Tables 2 and 3 may help relieve the patients of $\mathrm{OC}$.

Along with recent compelling evidence that OSC actually arises from the epithelial lining of fallopian tube, the true incidence of primary fallopian tube carcinoma (PFTC) has been substantially underestimated, which was previously considered as a rare neoplasm accounting for $0.14-1.8 \%$ of genital malignancies [208, 209]. Furthermore, aberrant p53/ KRASV12/c-Myc or p53/KRASV12/PI3K/AKT signaling is the minimum requirement for fallopian tube secretory epithelial cells (FTSECs) carcinogenesis [210], and increased copy number of PIK3CA has been observed in six fallopian tube carcinomas (FTCs) [211]. Thus, although the studies of PI3K/AKT signaling in FTC are numbered, there are still several clinical trials of PI3K/AKT inhibitors trying to treat patients with FTCs (Tables 2 and 3).

Cervical cancer (CC) is a prominent example of HPVrelated cancer, accounting for $3.2 \%$ of all human cancers with the mortality rate of $3.3 \%$ (Table 1 ). A litany of genetic alterations induced by HPVs in CC activate four major upstream pathways (GFR, Notch receptor, RAS isoforms and $\mathrm{p} 110 \alpha)$ to stimulate host cell survival, proliferation and carcinogenesis through the PI3K/AKT/mTOR pathway. Considerable overall genetic alterations of PI3K/AKT pathway in CC have emerged with PIK3CA (39\%) and PTEN (13\%, Table 1). In particular, the mutations of $P I K 3 C A$ $E 542 \mathrm{~K}$ and $E 545 \mathrm{~K}$ promote glycolysis and proliferation of CC in vitro and vivo [212]. NBPF1, ARHGAP17, miR99b, -181a2/181b2, -338, -383, -433 and -489, as well as LncRNA ANRIL, CRNDE, NEAT1 and LINC01305 are involved in the proliferation, invasion, autophagy or EMT via PI3K/AKT pathway [213-224]. Currently, only preclinical trials of PI3K inhibitor LY294002 has revealed it significantly radiosensitized CC cell lines in vitro and vivo [225, 226], and the terminated clinical trials of AKT inhibitor GSK2141795 (NCT01958112, Table 3) has tried to display a novel treatment approach to patients of CC.

Attributed to the global incidence $(2.1 \%)$ and mortality rate $(0.94 \%)$ of corpus uteri cancer, which is usually referred to endometrial cancer (EC), EC researches have gained a big momentum in recent years. Particularly, the endometrioid type of EC (EEC) progressing from intraepithelial endometrial neoplasia in a large proportion of cases belongs to ER-related cancer, and is directly associated with inactivation of PTEN. Hereby, the remarkable overall genetic alterations of PI3K/AKT pathway are shown in EC, such as: PIK3CA (34\%), PIK3R1 (19\%), PIK3R2 (5\%), AKT1 (3\%) and AKT2 (5\%), especially PTEN (32\%, Table 1). What's more, it's revealed that the majority of the G3 EEC samples have exhibited PIK3CA mutations (39\%) and PTEN mutations (67\%) [227]. Moreover, JQ1, NEDD4, PDCD4, miR-101, -494-3p, Lnc RNA LINP1 and MEG3 have shown their aptitudes for controlling tumorigenesis, proliferation, apoptosis, invasion, progression of EC cells via PI3K/AKT pathway [228-234]. Thus, EC patients may get benefit from the mounting clinical trials of PI3K/AKT inhibitors listed in Tables 2 and 3.

\section{Dysregulation of the PI3K/AKT Pathway in the genitourinary system tumors}

The morbidity of PCa ranks third in the world (7.1\%) since men obtain a small but finite benefit from PCa screening in terms of PCa-specific mortality, which is estimated as $3.8 \%$ globally [235] (Table 1). Seeing that loss of function of PTEN, resulting in dysregulated activation of the PI3K signaling network, is recognized as one of the most common driving events in PCa development [236], the overall genetic alterations of PI3K/AKT pathway in PCa have demonstrated with PIK3CA (6\%), and visible PTEN (18\%, Table 1). Sexual hormones have been historically associated with PCa for the androgen deprivation therapy (ADT), but scientific evidences including the increasingly emerging of castration resistant prostate cancer (CRPC) are inconsistent to decide whether their involvement is aetiological or a phenotype component of the disease. However, similar to BC, PRLR/ Jak2/STAT5 is also the main signaling pathway for activation in prostate gland, and PRLR-triggered pro-tumorigenic pathways in PCa include PI3K/AKT [172]. In addition, AEP, SCL/TAL1, SIRT3, Snail, MED15, STIM1, ST6Gal-I, Glyoxalase 2, ASF1B, GPCR48/LGR4, AP4, GCN5, SAG/ RBX2 E3, miR-7, -101, -129, -133a-3p, and -4638-5p, as well as LncRNA HCG11 and ATB govern tumorigenesis, progression, metastasis, EMT or castration resistant of $\mathrm{PCa}$ cells via PI3K/AKT pathway [237-256]. Preclinical trial of dual BRD4/PI3K inhibitor SF2523 [257] as well as a few of clinical trials of PI3K/AKT inhibitors may develop new therapeutic strategies for PCa patients (Tables 2 and 3).

Kidney cancer (KC) is a malignancy originating in the urinary tubular epithelial system of the renal parenchyma, which mainly means renal cell carcinoma (RCC). Accompanying with the recent hunt for the genetics causes of $\mathrm{KC}$, such as TFE3, TFEB, or MITF gene fusions, the overall genetic alterations of PI3K/AKT pathway comprising PIK3CA (2.8\%), PIK3R1 (0.4\%), PIK3R2 (0.3\%), AKT1 $(0.5 \%), A K T 2(0.6 \%)$ and PTEN (4\%, Table 1) are captured in $\mathrm{KC}$. To a further extent, PI3K/AKT/mTOR is identified as a highly enriched pathway in translocation RCC with 
TFE3 fusion (TFE3-tRCC) by miRNA microarray analysis [258]. Besides that PIK3R1 regulates EMT and stem-like phenotype of RCC cells through the AKT/GSK3 $\beta / C T N N B 1$ pathway [259], FoxO, PKCE, TPD52, NOTCH1, ETS2, miR-19b, -122, -182, -193a-3p, -195, and -224, as well as LncRNA MALAT1, TP73-AS1 and HOTTIP modulate proliferation, apoptosis, invasion, metastasis, or EMT via PI3K/ AKT pathway [260-272]. However, only a few of clinical trials of PI3K/AKT inhibitors in touch try to offer hope for KC patients (Tables 2 and 3).

Bladder cancer (BLCA) is complex disease mainly consisting of non-muscle-invasive bladder cancer (NMIBC, about $70 \%$ ), and muscle-invasive and metastatic bladder cancer (MIBC, about 30\%). Indeed, PIK3CA mutations are considered as an early genetic alteration associated with FGFR3 mutations in superficial papillary NMIBC [273] and the activation of the PI3K/AKT pathway is identified to induce urothelial carcinoma of the renal pelvis [274]. And the overall genetic alterations of PIK3CA (24\%) are described in BLCA (Table 1). It is further shown that PPAR $\gamma$, Sema4D, CCDC34, miR-29c, -143, -145 and -294, as well as LncRNA ATB, LINC00641, HULC, DUXAP10 and UCA1 regulate proliferation, migration, or invasion of BLCA cells via PI3K/AKT pathway [275-285]. Even though there is a significant unmet need for new therapies, however, at present only a small amount of clinical trials of BKM120 and GSK2636771 try to find out what PI3K inhibitor's prospects bring to the BLCA patients (Table 2).

Testicular cancer ( $\mathrm{Te} \mathrm{Ca}$ ) is the most common malignancy among men between 14 and 44 years in the world. Testicular germ cell tumors (TGCTs) are classified as seminoma and non-seminoma. Among the numerous genetic and environmental factors, cryptorchidism is the most common risk factor. Compared to the noted KRAS and NRAS mutations in TGCTs [286], the overall genetic alterations frequency of PIK3CA (3\%), PIK3RI (1.3\%), AKT1 (0.7\%) and PTEN $(0.7 \%)$ are much less, even though mutations in PIK3CA and $A K T 1$ are observed exclusively in cisplatin-resistant TGCTs [287]. AXIN1, TDRG1 and LncRNA H19 regulate cell viability, apoptosis or cisplatin resistance via the PI3K/ AKT/mTOR signaling pathway [288-290]. Unfortunately, $\mathrm{PI} 3 \mathrm{~K} / \mathrm{AKT}$ inhibitors have not yet applied in clinical trials of TGCT patients up to now.

\section{Description of the PI3K/AKT pathway in the hemato-immune system tumors}

Hematologic cancers are associated with hemato-immune system, which comprise lymphomas, myelomas and leukemias. Lymphoma, which is classified with Hodgkin's lymphoma (HL) and non-Hodgkin's lymphoma (NHL), and multiple myeloma (MM) emanate from the cells of the immune system, while leukemia originates from blood-forming tissues such as the bone marrow [291, 292].

$\mathrm{HL}$ is a rare $\mathrm{B}$-cell malignant neoplasm approximately accounting for $0.44 \%$ of all new cancers annually, which is classified into two discrete disease entities: classical Hodgkin lymphoma (CHL) and nodular lymphocyte-predominant Hodgkin lymphoma (NLPHL). With four subgroups including nodular sclerosis (NSCHL), mixed cellularity (MCCHL), lymphocyte depletion (LDCHL), and lymphocyte-rich (LRCHL), CHL is relatively less known about genetic lesions owing to the fact that the neoplastic Hodgkinand Reed-Sternberg (HRS) cells constituting only a small proportion of the tumor tissue [293]. But the prevalence of EBV in HRS cells varies according to the histological subtype and epidemiologic factors from highest frequency in MCCHL to the lowest in NSCHL, and EBV-encoded LMP1 utilizes the PI3K/AKT/mTOR signaling axis to induce ectopic CD137 expression in HRS cells, which results in enhancing the proliferation rate of HRS cells [294, 295]. Furthermore, differences related to EBV status or histological subtypes are observed for PI3K signaling in pediatric $\mathrm{HL}$ patients by using hybrid capture-targeted next-generation sequencing of circulating cell-free DNA (ccfDNA), where MCCHL and EBV+ cases were less frequently affected by mutations in ITPKB and GNA13 genes [296]. Recent evidences revealing that germinal center B-cells (GCB cells) are the cellular origin of HRS cells [294], and the facts that PRMT5 is upregulated by B-cell receptor signaling and forms a positive-feedback loop with PI3K/AKT in both activated B cell-like (ABC) and GCB cells of diffuse large B cell lymphoma (DLBCL) [297] suggest that PI3K/AKT may promote lymphomagenesis of GCB cells in HL, which is a remarkable coincidence with the other evidences that the PI3K/AKT pathway plays a pathogenetic role in HL [298, 299]. Thus, novel therapeutic options targeted PI3K/AKT pathway promote apoptosis or cell death, as well as regulate tumor microenvironment (TME) of HL cells in preclinical studies [300-302], and patients may get beneficial strategy in clinical trials of PI3K/AKT inhibitors (Tables 2 and 3).

As the most common malignancies of hemato-immune system in the world, NHL represents a wide spectrum of illnesses that vary from the most indolent to the most aggressive malignancies, which encompasses 2 main type: mature B-cell neoplasms (B-NHL, 85-90\%) and mature T-cell and natural killer (NK)-cell neoplasms (T/NK-NHL, 10-15\%; 2016 WHO). Indolent B-cell lymphomas (iB-NHL) represents $35-40 \%$ of NHL, and the most common subtypes include follicular lymphoma (FL), chronic lymphocytic leukemia/small lymphocytic lymphoma (CLL/SLL), a fraction of mantle cell lymphoma (MCL) cases, extramedullary, nodal and splenic marginal zone lymphoma (MZL), and lymphoplasmacytic lymphoma (LPL). On the other hand, the most common subtypes of aggressive B-NHL are large 
B-cell lymphomas, which is composed of DLBCL, not otherwise specified (NOS, 80\%) and additional 13 specific variants of DLBCL (20\%) including anaplastic (ALK + LBCL) and primary mediastinal lymphoma (PMLBCL), and other various kinds of DLBCL [303-306]. Anyway, the overall genetic alterations of PIK3CA (0.4\%), PIK3RI (0.5\%), PIK3R2 (0.1\%), AKT1 (0.1\%), AKT2 (0.1\%) and PTEN $(1.1 \%$, Table 1$)$ are observed statistically in NHL.

Apparently, two specific lymphomas, FL and DLBCL, account for about $65 \%$ of all NHL, and more importantly, the genomic profile of transformed FL shares similarities with that of GCB de novo DLBCL, and thus a thorough knowledge of these two entities related with PI3K/AKT pathway is essential [307-309]. Despite the recognized fact that overwhelming majority of FL cases have the characteristic $(14 ; 18)$ translocation involving the $\mathrm{IgH} / \mathrm{bcl}-2$ genes, while B-cells "arrested" in germinal centers of FL acquire dozens of additional genetic aberrations that influence key pathways controlling their physiological development including B Cell Receptor (BCR) signaling, PI3K/AKT pathway, and so on $[310,311]$. Especially, the facts that deletion of PIK3CD results in decreased number of marginal zone (MZ) $\mathrm{B}$ cells and pleural/peritoneal cavities in mice, as well as the evidences that PIK3CD-depleted B cells also fail to proliferate in vitro in response to BCR or CD40 signals and have impaired both humoral T-cell-dependent and T-cellindependent responses suggest that $\mathrm{p} 110 \delta$ plays a critical role in B cell homeostasis and function [312-314]. Consequently, following with the world's first selective PI3K $\delta$ inhibitor CAL-101 was approved by the FDA for the treatment of FL, CLL and SLL in 2014 [315] [NCT01282424, NCT02136511], the PI3K/AKT inhibitors have shown remarkable activity in an increasing subset of patients with NHL [316] (Tables 2, 3). Copanlisib (BAY 80-6946) and Duvelisib (IPI-145) are newly approved PI3K inhibitors that offer objective, although relatively short-lasting, responses in patients with heavily pre-treated FL and other NHL, and more such targeted agents may be approved soon [307, 317-320] (Tables 2 and 3).

As aforementioned, DLBCL is a highly aggressive heterogeneous disease with two subtypes: GCB and ABC [297]. One study shows that deregulation of the PI3K/AKT pathway by the inactivation of PTEN are found in 55\% of GCBDLBCL cases, but only in 14\% of non-GCB-DLBCL and worsens prognosis in 248 primary DLBCL patients [308]. Another study finds the PIK3CA amplification of $12.7 \%$ and PTEN loss of 12.2\% in DLBCL [321]. Furthermore, upregulation of PRMT5 and CXCR4 are involved in lymphomagenesis or resistance mechanism via the PI3K/AKT pathway in DLBCL cells [297, 322]. Preclinical trial of BAY80-6946 in DLBCL cells [323] and the clinical trials of BAY80-6946, INCB050465, CUDC-907 and MK2206 in patients with
DLBCL have improved our ability to manage patients with this disorder (Table 2).

T/NK-NHL is a heterogeneous group of malignancies often associated with poor clinical outcomes, and each malignancy within this group is characterized by unique clinicopathologic features, while $\mathrm{T}$ cell receptor/NF/kB (TCR/NF/kB) signaling highly enriched and dysregulation of JAK/STAT pathway, specifically aberrant STAT3 activation, are the common feature among these lymphomas [324-326]. A study with 426 adult T cell leukemia/lymphoma (ATL) cases associated with human T cell leukemia virus type-1 (HTLV-1) infection shows that PI3KCD mutation is also observed in 9 of $370(2.4 \%)$ cases besides the highly enriched for TCR/NF/kB signaling, $\mathrm{T}$ cell trafficking and other T cell-related pathways [324]. In addition, the alterations of PI3K signaling are involved in the multilobulated nucleus formation and cell proliferation in ATL cells [327]. Therefore, preclinical trial of CAL-101 inducing apoptosis in ATL cells [328] and a series of clinical trials of PI3K/AKT inhibitors are expected to offer new treatment regimens for patients with T/NK-NHL [316] (Tables 2, 3).

MM accounts for $0.88 \%$ of all cancers with the mortality rate $(1.1 \%)$. Almost all MM patients evolve from an asymptomatic pre-malignant stage termed monoclonal gammopathy of undetermined significance (MGUS). Despite that hotspot mutations of PIK3CA (E542K, E545K and H1047R) and $A K T 1$ genes (E17K) are absent in MM [329], the R310C mutation of PIK3CA gene [330] is identified in some cases of MM, as well as ROR2 drives the interaction of MM cells with TME through AKT activation [331]. Furthermore, only the blockade of PIK3CA is sufficient to induce cell death in a sizeable subgroup of $M M$ samples, and PIK3CA inhibitor BYL-719 in combination treatments with other compounds establishes anti-myeloma agents resulted in strongly enhanced MM cell death [332]. Therefore, some preclinical studies have examined PI3K/ AKT pathway inhibitors in MM, such as TAS-117, PI-103 and BEZ235 [333-335]. Fortunately, some of the clinical trials of PI3K/AKT inhibitors have demonstrated encouraging clinical activity in relapsed and relapsed/refractory (R/R) MM [336-339] (NCT01002248; NCT01476137; NCT00881946) (Tables 2 and 3).

The definition of leukemia is increasingly employed that an aberrant hyper-proliferation of immature blood cells either of the myeloid or lymphoid lineages forms liquid cancer, which is classified with acute or chronic. With morbidity $(2.4 \%)$ and mortality rate (3.2\%) across the world (Table 1), leukemia is a series of life-threatening malignant diseases, particularly in the adolescent and young adult (AYA) population, in which the acute leukemias are most prevalent [340]. Apart from the iconic $B C R / A B L$ oncogene formation in chronic myeloid leukemia (CML) and the genetic abnormalities frequently linked to treatment resistance and 
poor patient outcome in acute myeloid leukemia (AML), for example the unique $P M L-R A R A$ fusion in acute promyelocytic leukaemia (APL; AML M3), the PI3K/AKT pathway can function as a prosurvival factor in leukemia stem cells and early committed leukemic precursors with the following facts: Firstly, the overall genetic alterations of PIK3CA (0.6\%), PIK3R1 (0.6\%), PIK3R2 (0.4\%), AKT1 (0.5\%), AKT2 $(0.1 \%)$ and PTEN $(0.7 \%$, Table 1$)$ are observed in leukemia (Table 1). Secondly, PTEN plays critical roles in regulating not only hematopoietic stem cell activity through a Niche-dependent mechanism, but also hematopoiesis and leukemogenesis [341-343]. Furthermore, TAL1, c-Jun, EZH2, TRIM22, ETV6/RUNX1, miR-7, -22, -26b, -103, $-125 b,-126,-139-5 p,-181 c,-193 a,-628$, and -3142 , as well as LncRNA HULC, UCA1, linc00239 and LINC00265 control leukemogenesis, proliferation, apoptosis or chemoresistance via PI3K/AKT pathway [344-363]. Hereafter, $\mathrm{PI} 3 \mathrm{~K} / \mathrm{AKT}$ pathway inhibition is regarded as a therapeutic approach $[364,365]$ followed by the preclinical studies in leukemia cells $[366,367]$ in spite of the upregulated expression of P2RY14 in acute leukemia cells resistant to PI3K/ mTOR inhibition [368]. Since CAL-101 has been approved for marketing in patients with CLL/SLL, the clinical trials of PI3K/AKT inhibitors such as: BAY80-6946, KM120, YY-20394, BEZ235, PKI-587, IPI-145, CAL-101, TGR1202, MK2206 and GSK2141795 try to seek new therapeutic approach in relapse or refractory patients with CLL or newly diagnosed AML and acute lymphocytic leukemia (ALL, Tables 2 and 3).

\section{Featuring the PI3K/AKT pathway in the bone and soft tissue tumors}

Osteosarcoma (OS) is the most frequent primary solid malignancy of bone with the presence of malignant mesenchymal cells which produce osteoid and/or immature bone. The incidence of OS is higher in adolescence (8-11/million/year) than in the general population (2-3/million/year), and $>90 \%$ of OS patients died from pulmonary metastases before polychemotherapy. Although the biological and genetic studies of OS have made substantial progress, there has been no qualitative breakthrough in treatment over the past 30 years. Besides the alterations of TP53, RB1, ATRX and DLG2 in OS, total genetic alterations in the PI3K/AKT/ mTOR pathway are observed in 14 of 59 (24\%) OS patients, and PIK3CA and $m$ TOR are vital for the proliferation and survival of OS cells [369] (Table 1). Furthermore, dual $\mathrm{PI} 3 \mathrm{~K} / \mathrm{mTOR}$ inhibitors are effective at inducing apoptosis in primary OS cell cultures in vitro in both human and mouse OS, while specific PI3K or mTOR inhibitors are not effective [370], which is consistent with the preclinical study's result that BEZ235 inhibits proliferation and tumor development of OS cells in vivo [371].
Ewing's sarcoma (EWS), the second most common bone tumor in children and adolescents, is identified by the characteristic $\mathrm{t}(11 ; 22)$ chromosomal translocation and resulting oncogenic EWS-FLII fusion, for which no cure is currently available. Overall genetic alterations of the PI3K/AKT pathway are observed in EWS cases with PIK3CA (1.4\%), PIK3RI (0.5\%) and PTEN (0.5\%, Table 1), which play an important role in EWS pathogenesis [372]. Moreover, SOX2, Ski, miR-30d and -185 regulate proliferation, apoptosis, migration or progression of EWS cells though PI3K/ AKT pathway [373-376]. In addition, hnRNPM motifs are significantly enriched under the inhibition of the PI3K/AKT/ mTOR pathway by BEZ235 in EWS cells. On the other hand, hnRNPM down-expression revokes the BEZ235induced splicing changes including hnRNPM binding sites, enhanced BEZ235 cytotoxicity and limited the clonogenicity of EWS cells [377].

Currently, pediatric patients of OS or EWS may be beneficial from the ongoing clinical trials of BAY80-6946 (NCT03458728) and LY3023414 (NCT03213678, Table 2).

\section{The trait of the PI3K/AKT pathway in skin cancer}

Skin cancer is the most common carcinoma, affecting millions worldwide annually, which generally divided into malignant melanoma and non-melanoma skin cancer. Cutaneous melanoma ranks 20th among most common cancers worldwide and rapidly becomes life-threatening once it has spread. Even though solar ultraviolet exposure is the main environmental risk factor for cutaneous melanoma development, there are still genetic susceptibility factors, such as germline mutations in $p 16$ or $C D K 4$, and genesis of melanoma, such as the main genetic drivers $B R A F, N F 1$ and $N R A S$ mutations $[378,379]$. Since $B R A F^{V 600 E}$-mutated melanomagenesis is often accompanied by silencing of PTEN [380], the increasing genetic alterations in PI3K/ AKT pathway have been observed in melanoma including: PIK3CA (5\%) and PTEN (12\%, Table 1). Notably, dysfunction mutations of NF1 induce BRAF inhibitor resistance by activating RAS and its downstreams including both MAPK and PI3K/AKT/mTOR pathways in cutaneous melanoma [381, 382]. Even more, the onset of MEK1/2 inhibitor resistance in $B R A F$-mutated melanoma can be forestalled by PI3K blockade [383]. Other than that, ROR1, FOXC1, MIF, TGF $\beta$, IncRNA SNHG17, MIAT, MHENCR, OR3A4 and $\mathrm{H} 19$ regulate proliferation, progression, migration, invasion, metastasis or EMT-like transition though PI3K/AKT pathway in melanoma cells [384-392]. And now, a limited number of clinical trials of PI3K/AKT pathway inhibitors (BKM120, PX-866, GSK2636771, GSK2141795 and MK2206) try to find new ways other than current classic RAF/MEK/MAPK pathway inhibitors to treat the patients with metastatic or advanced melanomas (Tables 2 and 3). 


\section{Points of dispute or unanswered questions}

In general, ATC, NSCLC, EC, GC, CRC, BC, OC, CC, EC and BLCA exhibit higher frequencies of PIK3CA mutations than other tumors, while PTEN mutations are predominantly found in GBM, EC and PCa (Fig. 1, Table 1). No matter what kind of the genetic alteration happens in PI3K/AKT pathway, or the factor influences cellular behaviors via PI3K/AKT pathway, it leads to the hyperactivation of PI3K/AKT pathway. Growing evidences have shown that the hyper-activation of PI3K/AKT pathway in malignant tumor influences the tumorigenesis, proliferation, growth, apoptosis, invasion, metastasis, EMT, stem-like phenotype, immune microenvironment,

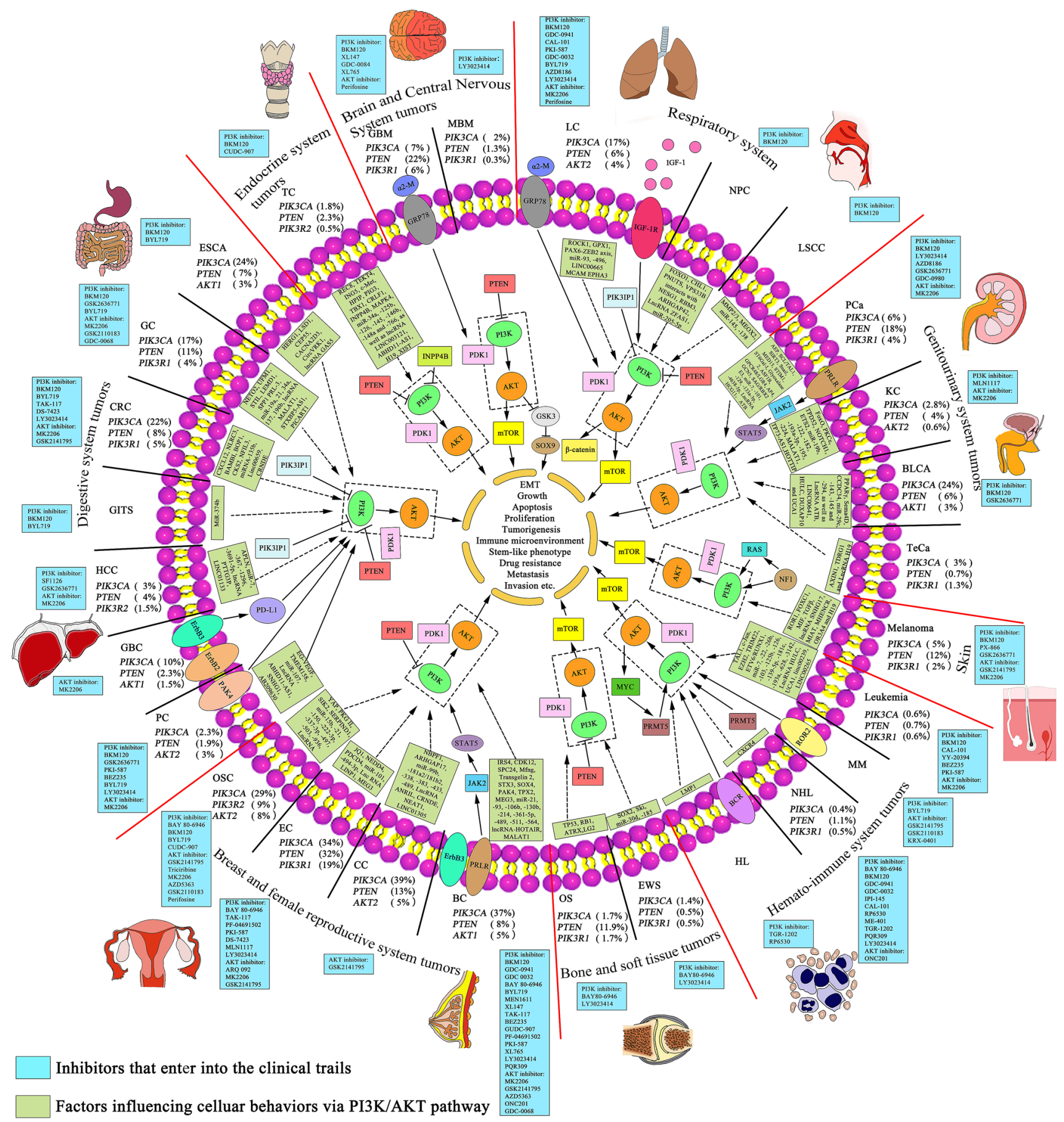

Fig. 1 Overview of the PI3K/AKT signaling cascades in cancers 
drug resistance of tumor cells (Fig. 1). Interestingly, some protein may play a dual role in PI3K/AKT pathway. For instance, unlike the previous understanding that INPP4B is a negative regulator of PI3K/AKT pathway in TC cells in vivo [49], the tumor-promoting features of INPP4B have yet been observed in leukemia and BC [393-395]. Why and how the INPP4B is a double-edged sword in PI3K/ AKT pathway is still a puzzle and it needs further research to evaluate the evidences.

\section{Potential research/future}

More and more promising PI3K/AKT pathway inhibitors seem to be useful to overcome malignant tumor, especially CAL-101 treated in patients with hemato-immune system tumors has achieved exhilarating results. Obviously, CAL101 not only causes a rapid and sustained reduction in lymphadenopathy, but also regulates the immune environment in CLL [396, 397]. However, things are more complicated than our envisage and there is always coexist with abnormal activity of other pathways interacted with PI3K/AKT pathway in tumors. For example, AKT inhibition induces the expression and phosphorylation of multiple RTKs, and the activated RTK signaling may attenuate their antitumor activity in $\mathrm{BC}$ cells, which suggest that combined inhibition of AKT and HER kinase activity is more effective than either alone [398]. There are some other embarrassments findings that small molecule PI3K/ AKT pathway inhibitors could promote the (re)phosphorylation of AKT2 which is linked to the redistribution and adaptive reprogramming of mitochondria, contributing to drug resistance and metastasis in GBM cells [399, 400]. Thence, novel combination therapies that target mitochondrial adaptation and PI3K pathway may achieve better efficacies than either alone in the clinic.

Collectively, we hope to feature PI3K/AKT pathway in cancers to the clinic and bring the promise of the novel inhibitors to the patients for targeted therapies.

Acknowledgements Juan Peng designed the review, wrote and revised the manuscript with input from Ningni Jiang, Qijie Dai, Xiaorui Su, Jianjiang Fu, Xuancheng Feng and Juan Peng. The literature search was performed and analyzed by Ningni Jiang, Qijie Dai, Xiaorui Su, Jianjiang Fu, Xuancheng Feng and Juan Peng. The figure of the review was mainly painted by Ningni Jiang, Qijie Dai, Xiaorui Su, and Xuancheng Feng. The major part of tables was completed by Juan Peng, Qijie Dai and Xiaorui Su. Xuancheng Feng participated in revising the review critically for the important intellectual content. All authors have read and approved the manuscript.

Funding This work has been supported by the National Natural Science Foundation of China (No. 81602631), the Guangdong Natural Science Foundation of China (No. 2016A030310280), the Student' Laboratory
Open Project of Guangzhou Medical University (C195015021), the Student's Research Project of The Third Clinical School of Guangzhou Medical University (2019A008) and the Undergraduate Innovation and Entrepreneurship Training Project of Guangdong Province (S201910570033).

\section{Compliance with ethical standards}

Conflict of interest No competing financial interests exist.

Open Access This article is licensed under a Creative Commons Attribution 4.0 International License, which permits use, sharing, adaptation, distribution and reproduction in any medium or format, as long as you give appropriate credit to the original author(s) and the source, provide a link to the Creative Commons licence, and indicate if changes were made. The images or other third party material in this article are included in the article's Creative Commons licence, unless indicated otherwise in a credit line to the material. If material is not included in the article's Creative Commons licence and your intended use is not permitted by statutory regulation or exceeds the permitted use, you will need to obtain permission directly from the copyright holder. To view a copy of this licence, visit http://creativecommons.org/licenses/by/4.0/.

\section{References}

1. Zhou M, Wang H, Zeng X et al (2019) Mortality, morbidity, and risk factors in China and its provinces, 1990-2017: a systematic analysis for the Global Burden of Disease Study 2017. Lancet 394(10204):1145-1158

2. Fayard E, Moncayo G, Hemmings BA et al (2010) Phosphatidylinositol 3-kinase signaling in thymocytes: the need for stringent control. Sci Signal 3(135):re5

3. Limon JJ, Fruman DA (2012) Akt and mTOR in B cell activation and differentiation. Front Immunol 3:228

4. Yuan TL, Cantley LC (2008) PI3K pathway alterations in cancer: variations on a theme. Oncogene 27(41):5497-5510

5. Marshall JDS, Whitecross DE, Mellor P et al (2019) Impact of p85alpha alterations in cancer. Biomolecules 9(1):E29

6. Carmona FJ, Montemurro F, Kannan S et al (2016) AKT signaling in ERBB2-amplified breast cancer. Pharmacol Ther 158:63-70

7. Alessi DR, Andjelkovic M, Caudwell B et al (1996) Mechanism of activation of protein kinase B by insulin and IGF-1. Embo J 15(23):6541-6551

8. Sarbassov DD, Guertin DA, Ali SM et al (2005) Phosphorylation and regulation of Akt/PKB by the rictor-mTOR complex. Science 307(5712):1098-1101

9. Walker KS, Deak M, Paterson A et al (1998) Activation of protein kinase $\mathrm{B}$ beta and gamma isoforms by insulin in vivo and by 3-phosphoinositide-dependent protein kinase-1 in vitro: comparison with protein kinase B alpha. Biochem J 331(Pt 1):299-308

10. Meier R, Alessi DR, Cron P et al (1997) Mitogenic activation, phosphorylation, and nuclear translocation of protein kinase Bbeta. J Biol Chem 272(48):30491-30497

11. Franke TF, Yang SI, Chan TO et al (1995) The protein kinase encoded by the Akt proto-oncogene is a target of the PDGFactivated phosphatidylinositol 3-kinase. Cell 81(5):727-736

12. Recabarren D, Alarcon M (2017) Gene networks in neurodegenerative disorders. Life Sci 183:83-97

13. Yu J, Zhang Y, McIlroy J et al (1998) Regulation of the p85/p110 phosphatidylinositol 3'-kinase: stabilization and inhibition of the p110alpha catalytic subunit by the $\mathrm{p} 85$ regulatory subunit. Mol Cell Biol 18(3):1379-1387 
14. Chagpar RB, Links PH, Pastor MC et al (2010) Direct positive regulation of PTEN by the $\mathrm{p} 85$ subunit of phosphatidylinositol 3-kinase. Proc Natl Acad Sci USA 107(12):5471-5476

15. Brown JS, Banerji U (2017) Maximising the potential of AKT inhibitors as anti-cancer treatments. Pharmacol Ther 172:101-115

16. Huck BR, Mochalkin I (2017) Recent progress towards clinically relevant ATP-competitive Akt inhibitors. Bioorg Med Chem Lett 27(13):2838-2848

17. Dolecek TA, Propp JM, Stroup NE et al (2012) CBTRUS statistical report: primary brain and central nervous system tumors diagnosed in the United States in 2005-2009. Neuro Oncol 14(Suppl 5):v1-49

18. Zhao HF, Wang J, Shao W et al (2017) Recent advances in the use of PI3K inhibitors for glioblastoma multiforme: current preclinical and clinical development. Mol Cancer 16(1):100

19. Brennan CW, Verhaak RG, McKenna A et al (2013) The somatic genomic landscape of glioblastoma. Cell 155(2):462-477

20. Weber GL, Parat MO, Binder ZA et al (2011) Abrogation of PIK3CA or PIK3R1 reduces proliferation, migration, and invasion in glioblastoma multiforme cells. Oncotarget 2(11):833-849

21. Zhao HF, Wang J, Jiang HR et al (2016) PI3K p110beta isoform synergizes with JNK in the regulation of glioblastoma cell proliferation and migration through Akt and FAK inhibition. J Exp Clin Cancer Res 35:78

22. Luk SK, Piekorz RP, Nurnberg B et al (2012) The catalytic phosphoinositol 3-kinase isoform p110delta is required for glioma cell migration and invasion. Eur J Cancer 48(1):149-157

23. Chen H, Mei L, Zhou L et al (2011) PTEN restoration and PIK3CB knockdown synergistically suppress glioblastoma growth in vitro and in xenografts. J Neurooncol 104(1):155-167

24. Jamieson S, Flanagan JU, Kolekar S et al (2011) A drug targeting only p110alpha can block phosphoinositide 3-kinase signalling and tumour growth in certain cell types. Biochem J 438(1):53-62

25. Holand K, Boller D, Hagel C et al (2014) Targeting class IA PI3K isoforms selectively impairs cell growth, survival, and migration in glioblastoma. PLoS ONE 9(4):e94132

26. Jones NM, Rowe MR, Shepherd PR et al (2016) Targeted inhibition of dominant PI3-kinase catalytic isoforms increase expression of stem cell genes in glioblastoma cancer stem cell models. Int J Oncol 49(1):207-216

27. Joy A, Kapoor M, Georges J et al (2016) The role of AKT isoforms in glioblastoma: AKT3 delays tumor progression. J Neurooncol 130(1):43-52

28. Kaley TJ, Panageas KS, Mellinghoff IK et al (2019) Phase II trial of an AKT inhibitor (perifosine) for recurrent glioblastoma. $\mathrm{J}$ Neurooncol 144(2):403-407

29. Alvarez-Garcia V, Tawil Y, Wise HM et al (2019) Mechanisms of PTEN loss in cancer: it's all about diversity. Semin Cancer Biol 59:66-79

30. Verhaak RG, Hoadley KA, Purdom E et al (2010) Integrated genomic analysis identifies clinically relevant subtypes of glioblastoma characterized by abnormalities in PDGFRA, IDH1, EGFR, and NF1. Cancer Cell 17(1):98-110

31. Dadey DYA, Kapoor V, Hoye K et al (2017) Antibody targeting GRP78 enhances the efficacy of radiation therapy in human glioblastoma and non-small cell lung cancer cell lines and tumor models. Clin Cancer Res 23(10):2556-2564

32. Li HF, Kim JS, Waldman T (2009) Radiation-induced Akt activation modulates radioresistance in human glioblastoma cells. Radiat Oncol 4:43

33. Misra UK, Pizzo SV (2014) Activated alpha2-macroglobulin binding to cell surface GRP78 induces T-loop phosphorylation of Akt1 by PDK1 in association with Raptor. PLoS ONE 9(2):e88373
34. Gottardo NG, Gajjar A (2006) Current therapy for medulloblastoma. Curr Treat Options Neurol 8(4):319-334

35. Suryo Rahmanto A, Savov V, Brunner A et al (2016) FBW7 suppression leads to SOX9 stabilization and increased malignancy in medulloblastoma. Embo J 35(20):2192-2212

36. Tan Y, Sangfelt O, Spruck C (2008) The Fbxw7/hCdc4 tumor suppressor in human cancer. Cancer Lett 271(1):1-12

37. Wang Z, Inuzuka H, Zhong J et al (2012) Tumor suppressor functions of FBW7 in cancer development and progression. FEBS Lett 586(10):1409-1418

38. Xing M (2010) Genetic alterations in the phosphatidylinositol-3 kinase/Akt pathway in thyroid cancer. Thyroid 20(7):697-706

39. Nilubol N, Kebebew E (2015) Should small papillary thyroid cancer be observed? A population-based study. Cancer 121(7):1017-1024

40. Landa I, Ibrahimpasic T, Boucai L et al (2016) Genomic and transcriptomic hallmarks of poorly differentiated and anaplastic thyroid cancers. J Clin Invest 126(3):1052-1066

41. Liu D, Shen X, Zhu G et al (2015) REC8 is a novel tumor suppressor gene epigenetically robustly targeted by the PI3K pathway in thyroid cancer. Oncotarget 6(36):39211-39224

42. Zheng Z, Zhou X, Cai Y et al (2018) TEKT4 promotes papillary thyroid cancer cell proliferation, colony formation, and metastasis through activating PI3K/Akt pathway. Endocr Pathol 29(4):310-316

43. Gao W, Han J (2018) Overexpression of ING5 inhibits HGFinduced proliferation, invasion and EMT in thyroid cancer cells via regulation of the c-Met/PI3K/Akt signaling pathway. Biomed Pharmacother 98:265-270

44. Byeon HK, Na HJ, Yang YJ et al (2016) c-Met-mediated reactivation of PI3K/AKT signaling contributes to insensitivity of BRAF(V600E) mutant thyroid cancer to BRAF inhibition. Mol Carcinog 55(11):1678-1687

45. Wang SC, Chai DS, Chen CB et al (2015) HPIP promotes thyroid cancer cell growth, migration and EMT through activating PI3K/ AKT signaling pathway. Biomed Pharmacother 75:33-39

46. Xu J, Cai J, Jin X et al (2015) PIG3 plays an oncogenic role in papillary thyroid cancer by activating the PI3K/AKT/PTEN pathway. Oncol Rep 34(3):1424-1430

47. Wang N, Li Y, Wei J et al (2019) TBX1 functions as a tumor suppressor in thyroid cancer through inhibiting the activities of the PI3K/AKT and MAPK/ERK pathways. Thyroid 29(3):378-394

48. Yu ST, Zhong Q, Chen RH et al (2018) CRLF1 promotes malignant phenotypes of papillary thyroid carcinoma by activating the MAPK/ERK and PI3K/AKT pathways. Cell Death Dis 9(3):371

49. Li Chew $C$, Lunardi A, Gulluni $F$ et al (2015) In vivo role of INPP4B in tumor and metastasis suppression through regulation of PI3K-AKT signaling at endosomes. Cancer Discov 5(7):740-751

50. Wang W, Shen T, Dong B et al (2019) MAPK4 overexpression promotes tumor progression via noncanonical activation of AKT/ mTOR signaling. J Clin Invest 129(3):1015-1029

51. Ma Y, Qin H, Cui Y (2013) MiR-34a targets GAS1 to promote cell proliferation and inhibit apoptosis in papillary thyroid carcinoma via PI3K/Akt/Bad pathway. Biochem Biophys Res Commun 441(4):958-963

52. Bu Q, You F, Pan G et al (2017) MiR-125b inhibits anaplastic thyroid cancer cell migration and invasion by targeting PIK3CD. Biomed Pharmacother 88:443-448

53. Rahman MA, Salajegheh A, Smith RA et al (2015) MicroRNA-126 suppresses proliferation of undifferentiated (BRAF(V600E) and BRAF(WT)) thyroid carcinoma through targeting PIK3R2 gene and repressing PI3K-AKT proliferationsurvival signalling pathway. Exp Cell Res 339(2):342-350 
54. Boufraqech M, Zhang L, Jain M et al (2014) miR-145 suppresses thyroid cancer growth and metastasis and targets AKT3. Endocr Relat Cancer 21(4):517-531

55. Ramirez-Moya J, Wert-Lamas L, Santisteban P (2018) MicroRNA-146b promotes PI3K/AKT pathway hyperactivation and thyroid cancer progression by targeting PTEN. Oncogene 37(25):3369-3383

56. Xu Y, Han YF, Zhu SJ et al (2017) miRNA148a inhibits cell growth of papillary thyroid cancer through STAT3 and PI3K/ AKT signaling pathways. Oncol Rep 38(5):3085-3093

57. Zhao J, Li Z, Chen Y et al (2019) MicroRNA766 inhibits papillary thyroid cancer progression by directly targeting insulin receptor substrate 2 and regulating the PI3K/Akt pathway. Int J Oncol 54(1):315-325

58. Min X, Liu K, Zhu $\mathrm{H}$ et al (2018) Long noncoding RNA LINC003121 inhibits proliferation and invasion of thyroid cancer cells by suppression of the phosphatidylinositol-3-kinase (PI3K)/Akt signaling pathway. Med Sci Monit 24:4592-4601

59. Wen J, Wang H, Dong T et al (2019) STAT3-induced upregulation of lncRNA ABHD11-AS1 promotes tumour progression in papillary thyroid carcinoma by regulating miR-1301-3p/ STAT3 axis and PI3K/AKT signalling pathway. Cell Prolif 52(2): 12569

60. Li X, Li Q, Jin X et al (2019) Long non-coding RNA H19 knockdown inhibits the cell viability and promotes apoptosis of thyroid cancer cells through regulating the PI3K/AKT pathway. Exp Ther Med 18(3):1863-1869

61. Liu H, Deng H, Zhao Y et al (2018) LncRNA XIST/miR-34a axis modulates the cell proliferation and tumor growth of thyroid cancer through MET-PI3K-AKT signaling. J Exp Clin Cancer Res 37(1):279

62. Charles RP, Silva J, Iezza G et al (2014) Activating BRAF and PIK3CA mutations cooperate to promote anaplastic thyroid carcinogenesis. Mol Cancer Res 12(7):979-986

63. Gibson WJ, Ruan DT, Paulson VA et al (2017) Genomic heterogeneity and exceptional response to dual pathway inhibition in anaplastic thyroid cancer. Clin Cancer Res 23(9):2367-2373

64. Kotian S, Zhang L, Boufraqech M et al (2017) Dual inhibition of HDAC and tyrosine kinase signaling pathways with CUDC-907 inhibits thyroid cancer growth and metastases. Clin Cancer Res 23(17):5044-5054

65. Hoffman PC, Mauer AM, Vokes EE (2000) Lung cancer. Lancet 355(9202):479-485

66. Perez-Ramirez C, Canadas-Garre M, Molina MA et al (2015) PTEN and PI3K/AKT in non-small-cell lung cancer. Pharmacogenomics 16(16):1843-1862

67. Kitagawa M, Liao PJ, Lee KH et al (2017) Dual blockade of the lipid kinase PIP4Ks and mitotic pathways leads to cancerselective lethality. Nat Commun 8(1):2200

68. Hu C, Zhou H, Liu Y et al (2019) ROCK1 promotes migration and invasion of nonsmallcell lung cancer cells through the PTEN/PI3K/FAK pathway. Int J Oncol 55(4):833-844

69. Chen B, Shen Z, Wu D et al (2019) Glutathione peroxidase 1 promotes NSCLC resistance to cisplatin via ROS-induced activation of PI3K/AKT pathway. Biomed Res Int 2019:7640547

70. Li C, Lyu J, Meng QH (2017) MiR-93 promotes tumorigenesis and metastasis of non-small cell lung cancer cells by activating the PI3K/Akt pathway via inhibition of LKB1/PTEN/CDKN1A. J Cancer 8(5):870-879

71. Ma R, Zhu P, Liu S et al (2019) miR-496 suppress tumorigenesis via targeting BDNF-mediated PI3K/Akt signaling pathway in non-small cell lung cancer. Biochem Biophys Res Commun 518(2):273-277

72. Wu DM, Zhang T, Liu YB et al (2019) The PAX6-ZEB2 axis promotes metastasis and cisplatin resistance in non-small cell lung cancer through PI3K/AKT signaling. Cell Death Dis 10(5):349

73. Liu X, Lu X, Zhen F et al (2019) LINC00665 induces acquired resistance to gefitinib through recruiting EZH2 and activating PI3K/AKT pathway in NSCLC. Mol Ther Nucleic Acids 16:155-161

74. Li L, Li JC, Yang H et al (2018) Expansion of cancer stem cell pool initiates lung cancer recurrence before angiogenesis. Proc Natl Acad Sci USA 115(38):E8948-e8957

75. Saygin C, Matei D, Majeti R et al (2019) Targeting cancer stemness in the clinic: from hype to hope. Cell Stem Cell 24(1):25-40

76. Tripathi SC, Fahrmann JF, Celiktas M et al (2017) MCAM mediates chemoresistance in small-cell lung cancer via the PI3K/ AKT/SOX2 signaling pathway. Cancer Res 77(16):4414-4425

77. Peng J, Wang Q, Liu H et al (2016) EPHA3 regulates the multidrug resistance of small cell lung cancer via the PI3K/BMX/ STAT3 signaling pathway. Tumour Biol 37(9):11959-11971

78. Ngan HL, Wang L, Lo KW et al (2018) Genomic landscapes of EBV-associated nasopharyngeal carcinoma vs HPV-associated head and neck cancer. Cancers (Basel) 10(7):E210

79. Yu JH, Chen L, Yu JY et al (2019) PI3K-PKB-mTOR hyperactivation in relation to nasopharyngeal carcinoma progression and prognosis. J Cell Biochem 120(6):10186-10194

80. Zhao M, Luo R, Liu Y et al (2016) miR-3188 regulates nasopharyngeal carcinoma proliferation and chemosensitivity through a FOXO1-modulated positive feedback loop with mTOR-p-PI3K/ AKT-c-JUN. Nat Commun 7:11309

81. Chen J, Jiang C, Fu L et al (2019) CHL1 suppresses tumor growth and metastasis in nasopharyngeal carcinoma by repressing $\mathrm{PI} 3 \mathrm{~K} / \mathrm{AKT}$ signaling pathway via interaction with Integrin beta1 and Merlin. Int J Biol Sci 15(9):1802-1815

82. Yu D, An X, Fan W et al (2019) PNUTS mediates ionizing radiation-induced CNE-2 nasopharyngeal carcinoma cell migration, invasion, and epithelial-mesenchymal transition via the PI3K/ AKT signaling pathway. Onco Targets Ther 12:1205-1214

83. Liang Z, Liu Z, Cheng $C$ et al (2019) VPS33B interacts with NESG1 to modulate EGFR/PI3K/AKT/c-Myc/P53/miR-133a-3p signaling and induce 5-fluorouracil sensitivity in nasopharyngeal carcinoma. Cell Death Dis 10(4):305

84. Ma R, Zhao LN, Yang $\mathrm{H}$ et al (2018) RNA binding motif protein 3 (RBM3) drives radioresistance in nasopharyngeal carcinoma by reducing apoptosis via the PI3K/AKT/Bcl-2 signaling pathway. Am J Transl Res 10(12):4130-4140

85. Hu Q, Lin X, Ding L et al (2018) ARHGAP42 promotes cell migration and invasion involving PI3K/Akt signaling pathway in nasopharyngeal carcinoma. Cancer Med 7(8):3862-3874

86. Wang X, Jin Q, Wang X et al (2019) LncRNA ZFAS1 promotes proliferation and migration and inhibits apoptosis in nasopharyngeal carcinoma via the PI3K/AKT pathway in vitro. Cancer Biomark 26(2):171-182

87. Zhang P, Lu X, Shi Z et al (2019) miR-205-5p regulates epithelial-mesenchymal transition by targeting PTEN via PI3K/AKT signaling pathway in cisplatin-resistant nasopharyngeal carcinoma cells. Gene 710:103-113

88. Chu EA, Kim YJ (2008) Laryngeal cancer: diagnosis and preoperative work-up. Otolaryngol Clin North Am 41(4):673-695

89. Mehanna H, Beech T, Nicholson T et al (2013) Prevalence of human papillomavirus in oropharyngeal and nonoropharyngeal head and neck cancer-systematic review and meta-analysis of trends by time and region. Head Neck 35(5):747-755

90. Lui VW, Hedberg ML, Li H et al (2013) Frequent mutation of the PI3K pathway in head and neck cancer defines predictive biomarkers. Cancer Discov 3(7):761-769 
91. Stransky N, Egloff AM, Tward AD et al (2011) The mutational landscape of head and neck squamous cell carcinoma. Science 333(6046): 1157-1160

92. Agrawal N, Frederick MJ, Pickering CR et al (2011) Exome sequencing of head and neck squamous cell carcinoma reveals inactivating mutations in NOTCH1. Science 333(6046): 1154-1157

93. Cancer Genome Atlas Network (2015) Comprehensive genomic characterization of head and neck squamous cell carcinomas. Nature 517(7536):576-582

94. Zhu Y, Yan L, Zhu W et al (2019) MMP2/3 promote the growth and migration of laryngeal squamous cell carcinoma via PI3K/ Akt-NF-kappaB-mediated epithelial-mesenchymal transformation. J Cell Physiol 10:1-10. https://doi.org/10.1002/jcp.28242

95. Tian L, Tao ZZ, Ye HP et al (2018) Over-expression of MEOX2 promotes apoptosis through inhibiting the PI3K/Akt pathway in laryngeal cancer cells. Neoplasma 65(5):745-752

96. Ye D, Zhou C, Deng H et al (2019) MicroRNA-145 inhibits growth of laryngeal squamous cell carcinoma by targeting the PI3K/Akt signaling pathway. Cancer Manag Res 11:3801-3812

97. Si F, Sun J, Wang C (2017) MicroRNA-138 suppresses cell proliferation in laryngeal squamous cell carcinoma via inhibiting EZH2 and PI3K/AKT signaling. Exp Ther Med 14(3):1967-1974

98. Lin DC, Hao JJ, Nagata Y et al (2014) Genomic and molecular characterization of esophageal squamous cell carcinoma. Nat Genet 46(5):467-473

99. Munari FF, Cruvinel-Carloni A, Lacerda CF et al (2018) PIK3CA mutations are frequent in esophageal squamous cell carcinoma associated with chagasic megaesophagus and are associated with a worse patient outcome. Infect Agent Cancer 13:43

100. Wang H, Yang X, Guo Y et al (2019) HERG1 promotes esophageal squamous cell carcinoma growth and metastasis through TXNDC 5 by activating the PI3K/AKT pathway. J Exp Clin Cancer Res 38(1):324

101. Hou G, Zhao Q, Zhang M et al (2019) LSD1 regulates Notch and $\mathrm{PI} 3 \mathrm{~K} / \mathrm{Akt} / \mathrm{mTOR}$ pathways through binding the promoter regions of Notch target genes in esophageal squamous cell carcinoma. Onco Targets Ther 12:5215-5225

102. Jia Y, Xiao Z, Gongsun X et al (2018) CEP55 promotes the proliferation, migration and invasion of esophageal squamous cell carcinoma via the PI3K/Akt pathway. Onco Targets Ther 11:4221-4232

103. Nie C, Qin X, Li X et al (2019) CACNA2D3 enhances the chemosensitivity of esophageal squamous cell carcinoma to cisplatin via inducing $\mathrm{Ca}(2+)$-mediated apoptosis and suppressing PI3K/ Akt pathways. Front Oncol 9:185

104. He Y, Mingyan E, Wang C et al (2019) CircVRK1 regulates tumor progression and radioresistance in esophageal squamous cell carcinoma by regulating miR-624-3p/PTEN/PI3K/AKT signaling pathway. Int J Biol Macromol 125:116-123

105. Wang G, Sun J, Zhao H et al (2018) Long non-coding RNA (lncRNA) growth arrest specific 5 (GAS5) suppresses esophageal squamous cell carcinoma cell proliferation and migration by inactivating phosphatidylinositol 3-kinase (PI3K)/AKT/mammalian target of rapamycin (mTOR) signaling pathway. Med Sci Monit 24:7689-7696

106. Li WQ, Zhang JY, Ma JL et al (2019) Effects of Helicobacter pylori treatment and vitamin and garlic supplementation on gastric cancer incidence and mortality: follow-up of a randomized intervention trial. BMJ 366:15016

107. Fang WL, Huang KH, Lan YT et al (2016) Mutations in PI3K/ AKT pathway genes and amplifications of PIK3CA are associated with patterns of recurrence in gastric cancers. Oncotarget 7(5):6201-6220
108. Ito C, Nishizuka SS, Ishida K et al (2017) Analysis of PIK3CA mutations and PI3K pathway proteins in advanced gastric cancer. J Surg Res 212:195-204

109. Liu JY, Jiang L, He T et al (2019) NETO2 promotes invasion and metastasis of gastric cancer cells via activation of PI3K/Akt/ NF-kappaB/Snail axis and predicts outcome of the patients. Cell Death Dis 10(3):162

110. Lin JX, Xie XS, Weng XF et al (2019) UFM1 suppresses invasive activities of gastric cancer cells by attenuating the expres7sion of PDK1 through PI3K/AKT signaling. J Exp Clin Cancer Res 38(1):410

111. Wang J, Zhang Y, Dou Z et al (2019) Knockdown of STIL suppresses the progression of gastric cancer by down-regulating the IGF-1/PI3K/AKT pathway. J Cell Mol Med 23(8):5566-5575

112. Li Q, Ge Y, Chen X et al (2019) LEM domain containing 1 promotes proliferation via activating the PI3K/Akt signaling pathway in gastric cancer. J Cell Biochem 120(9):15190-15201

113. Song SZ, Lin S, Liu JN et al (2019) Targeting of SPP1 by microRNA-340 inhibits gastric cancer cell epithelial-mesenchymal transition through inhibition of the PI3K/AKT signaling pathway. J Cell Physiol 234(10):18587-18601

114. Xiong J, Li Z, Zhang Y et al (2016) PRL-3 promotes the peritoneal metastasis of gastric cancer through the PI3K/Akt signaling pathway by regulating PTEN. Oncol Rep 36(4):1819-1828

115. Lu W, Xu Z, Zhang M et al (2014) MiR-19a promotes epithelial-mesenchymal transition through PI3K/AKT pathway in gastric cancer. Int J Clin Exp Pathol 7(10):7286-7296

116. Wang P, Guan Q, Zhou D et al (2018) miR-21 inhibitors modulate biological functions of gastric cancer cells via PTEN/ PI3K/mTOR pathway. DNA Cell Biol 37(1):38-45

117. Cao W, Yang W, Fan R et al (2014) miR-34a regulates cisplatin-induce gastric cancer cell death by modulating PI3K/AKT/ survivin pathway. Tumour Biol 35(2):1287-1295

118. Cheng Y, Li Y, Liu D et al (2014) miR-137 effects on gastric carcinogenesis are mediated by targeting Cox-2-activated PI3K/AKT signaling pathway. FEBS Lett 588(17):3274-3281

119. Li NA, Wang W, Xu B et al (2016) miR-196b regulates gastric cancer cell proliferation and invasion via $\mathrm{PI} 3 \mathrm{~K} / \mathrm{AKT} / \mathrm{mTOR}$ signaling pathway. Oncol Lett 11(3):1745-1749

120. Zhu K, Ren Q, Zhao Y (2019) lncRNA MALAT1 overexpression promotes proliferation, migration and invasion of gastric cancer by activating the PI3K/AKT pathway. Oncol Lett 17(6):5335-5342

121. Cen D, Huang H, Yang L et al (2019) Long noncoding RNA STXBP5-AS1 inhibits cell proliferation, migration, and invasion through inhibiting the PI3K/AKT signaling pathway in gastric cancer cells. Onco Targets Ther 12:1929-1936

122. Li JF, Li WH, Xue LL et al (2019) Long non-coding RNA PICART1 inhibits cell proliferation by regulating the PI3K/ AKT and MAPK/ERK signaling pathways in gastric cancer. Eur Rev Med Pharmacol Sci 23(2):588-597

123. Wieszczy P, Kaminski MF, Franczyk R et al (2019) Colorectal cancer incidence and mortality after removal of adenomas during screening colonoscopies. Gastroenterology pii S0016-5085(19):41344-41349

124. Jin J, Shi Y, Zhang S et al (2020) PIK3CA mutation and clinicopathological features of colorectal cancer: a systematic review and meta-analysis. Acta Oncol 59(1):66-74

125. Ma J, Sun X, Wang Y et al (2019) Fibroblast-derived CXCL12 regulates PTEN expression and is associated with the proliferation and invasion of colon cancer cells via PI3k/Akt signaling. Cell Commun Signal 17(1):119

126. Karki R, Man SM, Malireddi RKS et al (2016) NLRC3 is an inhibitory sensor of PI3K-mTOR pathways in cancer. Nature 540(7634):583-587 
127. Qi J, Yu Y, Akilli Ozturk O et al (2016) New Wnt/beta-catenin target genes promote experimental metastasis and migration of colorectal cancer cells through different signals. Gut 65(10):1690-1701

128. Valeri N, Braconi C, Gasparini P et al (2014) MicroRNA$135 \mathrm{~b}$ promotes cancer progression by acting as a downstream effector of oncogenic pathways in colon cancer. Cancer Cell 25(4):469-483

129. Tsai KW, Lo YH, Liu H et al (2018) Linc00659, a long noncoding RNA, acts as novel oncogene in regulating cancer cell growth in colorectal cancer. Mol Cancer 17(1):72

130. Ellis BC, Graham LD (1843) Molloy PL (2014) CRNDE, a long non-coding RNA responsive to insulin/IGF signaling, regulates genes involved in central metabolism. Biochim Biophys Acta 2:372-386

131. Goodwin R, Jonker D, Chen E et al (2019) A phase Ib study of a PI3Kinase inhibitor BKM120 in combination with panitumumab in patients with KRAS wild-type advanced colorectal cancer. Invest New Drugs. https://doi.org/10.1007/s10637-01900814-3

132. Hirota S, Isozaki K, Moriyama Y et al (1998) Gain-of-function mutations of c-kit in human gastrointestinal stromal tumors. Science 279(5350):577-580

133. Joensuu H, Rutkowski P, Nishida T et al (2015) KIT and PDGFRA mutations and the risk of GI stromal tumor recurrence. J Clin Oncol 33(6):634-642

134. Ohshima K, Fujiya K, Nagashima T et al (2019) Driver gene alterations and activated signaling pathways toward malignant progression of gastrointestinal stromal tumors. Cancer Sci 110(12):3821-3833

135. Rossi S, Ou W, Tang D et al (2006) Gastrointestinal stromal tumours overexpress fatty acid synthase. J Pathol 209(3):369-375

136. Li CF, Fang FM, Chen YY et al (2017) Overexpressed fatty acid synthase in gastrointestinal stromal tumors: targeting a progression-associated metabolic driver enhances the antitumor effect of imatinib. Clin Cancer Res 23(16):4908-4918

137. Long ZW, Wu JH, Cai H et al (2018) MiR-374b promotes proliferation and inhibits apoptosis of human GIST cells by inhibiting PTEN through activation of the PI3K/Akt pathway. Mol Cells 41(6):532-544

138. Zook P, Pathak HB, Belinsky MG et al (2017) Combination of imatinib mesylate and AKT inhibitor provides synergistic effects in preclinical study of gastrointestinal stromal tumor. Clin Cancer Res 23(1):171-180

139. He X, Zhu Z, Johnson C et al (2008) PIK3IP1, a negative regulator of PI3K, suppresses the development of hepatocellular carcinoma. Cancer Res 68(14):5591-5598

140. Chen H, Wong CC, Liu D et al (2019) APLN promotes hepatocellular carcinoma through activating PI3K/Akt pathway and is a druggable target. Theranostics 9(18):5246-5260

141. Fang Y, Xue JL, Shen Q et al (2012) MicroRNA-7 inhibits tumor growth and metastasis by targeting the phosphoinositide 3-kinase/Akt pathway in hepatocellular carcinoma. Hepatology 55(6):1852-1862

142. Wang $Z$, Luo $Y$ (2019) MicroRNA-367 promotes progression of hepatocellular carcinoma through PTEN /PI3K/AKT signaling pathway. Biosci Rep. https://doi.org/10.1042/BSR20182466

143. Xu Q, Liu X, Liu Z et al (2017) MicroRNA-1296 inhibits metastasis and epithelial-mesenchymal transition of hepatocellular carcinoma by targeting SRPK1-mediated PI3K/AKT pathway. Mol Cancer 16(1):103

144. Du W, Zhang X, Wan Z (2019) miR-3691-5p promotes hepatocellular carcinoma cell migration and invasion through activating PI3K/Akt signaling by targeting PTEN. Onco Targets Ther 12:4897-4906
145. Huang JL, Cao SW, Ou QS et al (2018) The long non-coding RNA PTTG3P promotes cell growth and metastasis via up-regulating PTTG1 and activating PI3K/AKT signaling in hepatocellular carcinoma. Mol Cancer 17(1):93

146. Zheng YF, Zhang XY, Bu YZ (2019) LINC01133 aggravates the progression of hepatocellular carcinoma by activating the PI3K/ AKT pathway. J Cell Biochem 120(3):4172-4179

147. Zhao S, Cao Y, Liu SB et al (2016) The E545K mutation of PIK3CA promotes gallbladder carcinoma progression through enhanced binding to EGFR. J Exp Clin Cancer Res 35(1):97

148. Li M, Liu F, Zhang F et al (2019) Genomic ERBB2/ERBB3 mutations promote PD-L1-mediated immune escape in gallbladder cancer: a whole-exome sequencing analysis. Gut 68(6):1024-1033

149. Zhang F, Xiang S, Cao Y et al (2017) EIF3D promotes gallbladder cancer development by stabilizing GRK2 kinase and activating PI3K-AKT signaling pathway. Cell Death Dis 8(6):e2868

150. Zhang Z, Zheng X, Li J et al (2019) Overexpression of UBR5 promotes tumor growth in gallbladder cancer via PTEN/PI3K/ Akt signal pathway. J Cell Biochem. https://doi.org/10.1002/ jcb. 28431

151. Hao J, Yang Z, Wang L et al (2017) Downregulation of BRD4 inhibits gallbladder cancer proliferation and metastasis and induces apoptosis via PI3K/AKT pathway. Int J Oncol 51(3):823-831

152. Li H, Zhang Y, Hai J et al (2018) Knockdown of TRIM31 suppresses proliferation and invasion of gallbladder cancer cells by down-regulating MMP2/9 through the PI3K/Akt signaling pathway. Biomed Pharmacother 103:1272-1278

153. Cai Q, Wang ZQ, Wang SH et al (2016) Upregulation of long non-coding RNA LINC00152 by SP1 contributes to gallbladder cancer cell growth and tumor metastasis via PI3K/AKT pathway. Am J Transl Res 8(10):4068-4081

154. Shin EJ, Canto MI (2012) Pancreatic cancer screening. Gastroenterol Clin N Am 41(1):143-157

155. Delpu Y, Hanoun N, Lulka H et al (2011) Genetic and epigenetic alterations in pancreatic carcinogenesis. Curr Genomics 12(1):15-24

156. Carter H, Samayoa J, Hruban RH et al (2010) Prioritization of driver mutations in pancreatic cancer using cancer-specific highthroughput annotation of somatic mutations (CHASM). Cancer Biol Ther 10(6):582-587

157. di Magliano MP, Logsdon CD (2013) Roles for KRAS in pancreatic tumor development and progression. Gastroenterology 144(6):1220-1229

158. Bournet B, Buscail C, Muscari F et al (2016) Targeting KRAS for diagnosis, prognosis, and treatment of pancreatic cancer: hopes and realities. Eur J Cancer 54:75-83

159. Bittoni A, Mandolesi A, Andrikou K et al (2015) HER family receptor expression and prognosis in pancreatic cancer. Int J Biol Markers 30(3):e327-332

160. Baer R, Cintas C, Dufresne M et al (2014) Pancreatic cell plasticity and cancer initiation induced by oncogenic Kras is completely dependent on wild-type PI 3-kinase p110alpha. Genes Dev 28(23):2621-2635

161. King H, Thillai K, Whale A et al (2017) PAK4 interacts with p85 alpha: implications for pancreatic cancer cell migration. Sci Rep 7:42575

162. Yan X, Hui Y, Hua Y et al (2019) EG-VEGF silencing inhibits cell proliferation and promotes cell apoptosis in pancreatic carcinoma via PI3K/AKT/mTOR signaling pathway. Biomed Pharmacother 109:762-769

163. Fu Y, Yao N, Ding D et al (2020) TMEM158 promotes pancreatic cancer aggressiveness by activation of TGFbeta1 and PI3K/AKT signaling pathway. J Cell Physiol 235(3):2761-2775 
164. Xiong J, Wang D, Wei A et al (2017) Deregulated expression of miR-107 inhibits metastasis of PDAC through inhibition PI3K/Akt signaling via caveolin-1 and PTEN. Exp Cell Res 361(2):316-323

165. Qiao X, Lv SX, Qiao Y et al (2018) Long noncoding RNA ABHD11-AS1 predicts the prognosis of pancreatic cancer patients and serves as a promoter by activating the PI3K-AKT pathway. Eur Rev Med Pharmacol Sci 22(24):8630-8639

166. Zhang Y, Zhang R, Luo $\mathrm{G}$ et al (2018) Long noncoding RNA SNHG1 promotes cell proliferation through PI3K/AKT signaling pathway in pancreatic ductal adenocarcinoma. J Cancer 9(15):2713-2722

167. Wang L, Wang F, Na L et al (2018) LncRNA AB209630 inhibits gemcitabine resistance cell proliferation by regulating PI3K/AKT signaling in pancreatic ductal adenocarcinoma. Cancer Biomark 22(1):169-174

168. Croessmann S, Formisano L, Kinch LN et al (2019) Combined blockade of activating ERBB2 mutations and ER results in synthetic lethality of ER+/HER2 mutant breast cancer. Clin Cancer Res 25(1):277-289

169. Nixon MJ, Formisano L, Mayer IA et al (2019) PIK3CA and MAP3K1 alterations imply luminal A status and are associated with clinical benefit from pan-PI3K inhibitor buparlisib and letrozole in ER+ metastatic breast cancer. NPJ Breast Cancer $5: 31$

170. Adamo B, Deal AM, Burrows E et al (2011) Phosphatidylinositol 3-kinase pathway activation in breast cancer brain metastases. Breast Cancer Res 13(6):R125

171. Ippen FM, Alvarez-Breckenridge CA, Kuter BM et al (2019) The dual PI3K/mTOR pathway inhibitor GDC-0084 achieves antitumor activity in PIK3CA-mutant breast cancer brain metastases. Clin Cancer Res 25(11):3374-3383

172. Goffin V (2017) Prolactin receptor targeting in breast and prostate cancers: new insights into an old challenge. Pharmacol Ther 179:111-126

173. Ikink GJ, Boer M, Bakker ER et al (2016) IRS4 induces mammary tumorigenesis and confers resistance to HER2-targeted therapy through constitutive PI3K/AKT-pathway hyperactivation. Nat Commun 7:13567

174. Choi HJ, Jin S, Cho H et al (2019) CDK12 drives breast tumor initiation and trastuzumab resistance via WNT and IRS1-ErbBPI3K signaling. EMBO Rep 20(10):e48058

175. Zhou J, Pei Y, Chen G et al (2018) SPC24 Regulates breast cancer progression by PI3K/AKT signaling. Gene 675:272-277

176. Zhang S, Chung WC, Wu G et al (2015) Manic fringe promotes a claudin-low breast cancer phenotype through notch-mediated PIK3CG induction. Cancer Res 75(10):1936-1943

177. Liu L, Meng T, Zheng X et al (2019) Transgelin 2 promotes paclitaxel resistance, migration, and invasion of breast cancer by directly interacting with PTEN and activating PI3K/Akt/GSK3beta pathway. Mol Cancer Ther 18(12):2457-2468

178. Nan H, Han L, Ma J et al (2018) STX3 represses the stability of the tumor suppressor PTEN to activate the PI3K-Akt-mTOR signaling and promotes the growth of breast cancer cells. Biochim Biophys Acta Mol Basis Dis 1864:1684-1692

179. Mehta GA, Parker JS, Silva GO et al (2017) Amplification of SOX4 promotes PI3K/Akt signaling in human breast cancer. Breast Cancer Res Treat 162(3):439-450

180. He LF, Xu HW, Chen M et al (2017) Activated-PAK4 predicts worse prognosis in breast cancer and promotes tumorigenesis through activation of PI3K/AKT signaling. Oncotarget 8(11):17573-17585

181. Chen M, Zhang H, Zhang G et al (2018) Targeting TPX2 suppresses proliferation and promotes apoptosis via repression of the $\mathrm{PI} 3 \mathrm{k} / \mathrm{AKT} / \mathrm{P} 21$ signaling pathway and activation of p53 pathway in breast cancer. Biochem Biophys Res Commun 507(1-4):74-82
182. Zhu M, Wang X, Gu Y et al (2019) MEG3 overexpression inhibits the tumorigenesis of breast cancer by downregulating miR-21 through the PI3K/Akt pathway. Arch Biochem Biophys 661:22-30

183. Li N, Miao Y, Shan Y et al (2017) MiR-106b and miR-93 regulate cell progression by suppression of PTEN via PI3K/Akt pathway in breast cancer. Cell Death Dis 8(5):e2796

184. Miao Y, Zheng W, Li N et al (2017) MicroRNA-130b targets PTEN to mediate drug resistance and proliferation of breast cancer cells via the PI3K/Akt signaling pathway. Sci Rep 7:41942

185. Wang F, Li L, Chen $Z$ et al (2016) MicroRNA-214 acts as a potential oncogene in breast cancer by targeting the PTEN-PI3K/ Akt signaling pathway. Int J Mol Med 37(5):1421-1428

186. Han J, Yu J, Dai Y et al (2019) Overexpression of miR-361-5p in triple-negative breast cancer (TNBC) inhibits migration and invasion by targeting RQCD1 and inhibiting the EGFR/PI3K/ Akt pathway. Bosn J Basic Med Sci 19(1):52-59

187. Chen X, Wang YW, Xing AY et al (2016) Suppression of SPIN1mediated PI3K-Akt pathway by miR-489 increases chemosensitivity in breast cancer. J Pathol 239(4):459-472

188. Zhao Y, Pang W, Yang N et al (2018) MicroRNA-511 inhibits malignant behaviors of breast cancer by directly targeting SOX9 and regulating the PI3K/Akt pathway. Int J Oncol 53(6):2715-2726

189. Mutlu M, Saatci O, Ansari SA et al (2016) miR-564 acts as a dual inhibitor of PI3K and MAPK signaling networks and inhibits proliferation and invasion in breast cancer. Sci Rep 6:32541

190. Li Z, Qian J, Li J et al (2019) Knockdown of lncRNA-HOTAIR downregulates the drug-resistance of breast cancer cells to doxorubicin via the PI3K/AKT/mTOR signaling pathway. Exp Ther Med 18(1):435-442

191. Xu S, Sui S, Zhang J et al (2015) Downregulation of long noncoding RNA MALAT1 induces epithelial-to-mesenchymal transition via the PI3K-AKT pathway in breast cancer. Int J Clin Exp Pathol 8(5):4881-4891

192. Kuo KT, Mao TL, Jones $S$ et al (2009) Frequent activating mutations of PIK3CA in ovarian clear cell carcinoma. Am J Pathol 174(5):1597-1601

193. Verhaak RG, Tamayo P, Yang JY et al (2013) Prognostically relevant gene signatures of high-grade serous ovarian carcinoma. J Clin Invest 123(1):517-525

194. Wei X, Jia Y, Lou H et al (2019) Targeting YAP suppresses ovarian cancer progression through regulation of the PI3K/Akt/ mTOR pathway. Oncol Rep 42(6):2768-2776

195. Wu Y, Cai Q, Li W et al (2019) Active PKG II inhibited the growth and migration of ovarian cancer cells through blocking Raf/MEK and PI3K/Akt signaling pathways. Biosci Rep. https ://doi.org/10.1042/BSR20190405

196. Gao T, Zhang X, Zhao J et al (2020) SIK2 promotes reprogramming of glucose metabolism through PI3K/AKT/HIF-1alpha pathway and Drp1-mediated mitochondrial fission in ovarian cancer. Cancer Lett 469:89-101

197. Guo Q, Zhu L, Wang C et al (2019) SERPIND1 affects the malignant biological behavior of epithelial ovarian cancer via the PI3K/AKT pathway: a mechanistic study. Front Oncol 9:954

198. Li GC, Qin XL, Song HH et al (2019) Upregulated microRNA-15b alleviates ovarian cancer through inhitbition of the PI3K/Akt pathway by targeting LPAR3. J Cell Physiol 234(12):22331-22342

199. Liu HY, Zhang YY, Zhu BL et al (2019) miR-21 regulates the proliferation and apoptosis of ovarian cancer cells through PTEN/ PI3K/AKT. Eur Rev Med Pharmacol Sci 23(10):4149-4155

200. Wuerkenbieke D, Wang J, Li Y et al (2015) miRNA-150 downregulation promotes pertuzumab resistance in ovarian cancer cells via AKT activation. Arch Gynecol Obstet 292(5):1109-1116 
201. Fu X, Li Y, Alvero A et al (2016) MicroRNA-222-3p/GNAI2/ AKT axis inhibits epithelial ovarian cancer cell growth and associates with good overall survival. Oncotarget 7(49):80633-80654

202. Zhang Z, Zhang L, Wang B et al (2020) MiR-337-3p suppresses proliferation of epithelial ovarian cancer by targeting PIK3CA and PIK3CB. Cancer Lett 469:54-67

203. Wang W, Ren F, Wu Q et al (2014) MicroRNA-497 suppresses angiogenesis by targeting vascular endothelial growth factor A through the PI3K/AKT and MAPK/ERK pathways in ovarian cancer. Oncol Rep 32(5):2127-2133

204. Wu D, Lu P, Mi X et al (2018) Downregulation of miR-503 contributes to the development of drug resistance in ovarian cancer by targeting PI3K p85. Arch Gynecol Obstet 297(3):699-707

205. Li C, Yu S, Wu S et al (2019) MicroRNA-936 targets FGF2 to inhibit epithelial ovarian cancer aggressiveness by deactivating the PI3K/Akt pathway. Onco Targets Ther 12:5311-5322

206. Jin Y, Feng SJ, Qiu S et al (2017) LncRNA MALAT1 promotes proliferation and metastasis in epithelial ovarian cancer via the PI3K-AKT pathway. Eur Rev Med Pharmacol Sci 21(14):3176-3184

207. Li J, Feng L, Tian C et al (2018) Long noncoding RNA-JPX predicts the poor prognosis of ovarian cancer patients and promotes tumor cell proliferation, invasion and migration by the $\mathrm{PI} 3 \mathrm{~K} / \mathrm{Akt} / \mathrm{mTOR}$ signaling pathway. Eur Rev Med Pharmacol Sci 22(23):8135-8144

208. Kurman RJ, Shih Ie M (2010) The origin and pathogenesis of epithelial ovarian cancer: a proposed unifying theory. Am J Surg Pathol 34(3):433-443

209. Gungorduk K, Ertas IE, Ozdemir A et al (2015) Prognostic significance of retroperitoneal lymphadenectomy, preoperative neutrophil lymphocyte ratio and platelet lymphocyte ratio in primary fallopian tube carcinoma: a multicenter study. Cancer Res Treat 47(3):480-488

210. Nakamura K, Nakayama K, Ishikawa N et al (2018) Reconstitution of high-grade serous ovarian carcinoma from primary fallopian tube secretory epithelial cells. Oncotarget 9(16):12609-12619

211. Snijders AM, Nowee ME, Fridlyand J et al (2003) Genomewide-array-based comparative genomic hybridization reveals genetic homogeneity and frequent copy number increases encompassing CCNE1 in fallopian tube carcinoma. Oncogene 22(27):4281-4286

212. Jiang W, He T, Liu S et al (2018) The PIK3CA E542K and E545K mutations promote glycolysis and proliferation via induction of the beta-catenin/SIRT3 signaling pathway in cervical cancer. J Hematol Oncol 11(1):139

213. Qin Y, Tang X, Liu M (2016) Tumor-suppressor gene nbpf1 inhibits invasion and PI3K/mTOR signaling in cervical cancer cells. Oncol Res 23(1-2):13-20

214. Guo Q, Xiong Y, Song Y et al (2019) ARHGAP17 suppresses tumor progression and up-regulates $\mathrm{P} 21$ and $\mathrm{P} 27$ expression via inhibiting PI3K/AKT signaling pathway in cervical cancer. Gene 692:9-16

215. Li YJ, Wang Y, Wang YY (2019) MicroRNA-99b suppresses human cervical cancer cell activity by inhibiting the PI3K/AKT/mTOR signaling pathway. J Cell Physiol 234(6):9577-9591

216. Mei Q, Li X, Zhang K et al (2017) Genetic and methylationinduced loss of miR-181a2/181b2 within chr9q33.3 facilitates tumor growth of cervical cancer through the PIK3R3/Akt/FoxO signaling pathway. Clin Cancer Res 23(2):575-586

217. Lu R, Yang Z, Xu G et al (2018) miR-338 modulates proliferation and autophagy by PI3K/AKT/mTOR signaling pathway in cervical cancer. Biomed Pharmacother 105:633-644

218. Teng P, Jiao Y, Hao M et al (2018) microRNA-383 suppresses the PI3K-AKT-MTOR signaling pathway to inhibit development of cervical cancer via down-regulating PARP2. J Cell Biochem 119(7):5243-5252

219. Xu J, Zhu W, Chen L et al (2018) MicroRNA433 inhibits cell growth and induces apoptosis in human cervical cancer through PI3K/AKT signaling by targeting FAK. Oncol Rep 40(6):3469-3478

220. Juan C, Hua Q, Ruping Z et al (2018) miRNA-489 as a biomarker in diagnosis and treatment of cervical cancer. Bratisl Lek Listy 119(5):278-283

221. Zhang D, Sun G, Zhang $\mathrm{H}$ et al (2017) Long non-coding RNA ANRIL indicates a poor prognosis of cervical cancer and promotes carcinogenesis via PI3K/Akt pathways. Biomed Pharmacother 85:511-516

222. Yang HY, Huang CP, Cao MM et al (2018) Long non-coding RNA CRNDE may be associated with poor prognosis by promoting proliferation and inhibiting apoptosis of cervical cancer cells through targeting PI3K/AKT. Neoplasma 65(6):872-880

223. Guo HM, Yang SH, Zhao SZ et al (2018) LncRNA NEAT1 regulates cervical carcinoma proliferation and invasion by targeting AKT/PI3K. Eur Rev Med Pharmacol Sci 22(13):4090-4097

224. Yan SP, Chu DX, Qiu HF et al (2019) LncRNA LINC01305 silencing inhibits cell epithelial-mesenchymal transition in cervical cancer by inhibiting TNXB-mediated PI3K/Akt signalling pathway. J Cell Mol Med 23(4):2656-2666

225. Lee CM, Fuhrman CB, Planelles V et al (2006) Phosphatidylinositol 3-kinase inhibition by LY294002 radiosensitizes human cervical cancer cell lines. Clin Cancer Res 12(1):250-256

226. Liu Y, Cui B, Qiao Y et al (2011) Phosphoinositide-3-kinase inhibition enhances radiosensitization of cervical cancer in vivo. Int J Gynecol Cancer 21(1):100-105

227. Malentacchi F, Turrini I, Sorbi F et al (2019) Pilot investigation of the mutation profile of PIK3CA/PTEN genes (PI3K pathway) in grade 3 endometrial cancer. Oncol Rep 41(3):1560-1574

228. Qiu H, Li J, Clark LH et al (2016) JQ1 suppresses tumor growth via PTEN/PI3K/AKT pathway in endometrial cancer. Oncotarget 7(41):66809-66821

229. Zhang Y, Goodfellow R, Li Y et al (2015) NEDD4 ubiquitin ligase is a putative oncogene in endometrial cancer that activates IGF-1R/PI3K/Akt signaling. Gynecol Oncol 139(1):127-133

230. Wang X, Li Y, Wan L et al (2019) Downregulation of PDCD4 induced by progesterone is mediated by the PI3K/AKT signaling pathway in human endometrial cancer cells. Oncol Rep 42(2):849-856

231. Zhang S, Wang M, Li Q et al (2017) MiR-101 reduces cell proliferation and invasion and enhances apoptosis in endometrial cancer via regulating PI3K/Akt/mTOR. Cancer Biomark 21(1):179-186

232. Zhu L, Wang X, Wang $T$ et al (2019) miR4943p promotes the progression of endometrial cancer by regulating the PTEN/PI3K/ AKT pathway. Mol Med Rep 19(1):581-588

233. Zhang XH, Li M, Kang YJ et al (2019) Long non-coding RNA LINP1 functions as an oncogene in endometrial cancer progression by regulating the PI3K/AKT signaling pathway. Eur Rev Med Pharmacol Sci 23(16):6830-6838

234. Sun KX, Wu DD, Chen S et al (2017) LncRNA MEG3 inhibit endometrial carcinoma tumorigenesis and progression through PI3K pathway. Apoptosis 22(12):1543-1552

235. Barry MJ, Simmons LH (2017) Prevention of prostate cancer morbidity and mortality: primary prevention and early detection. Med Clin N Am 101(4):787-806

236. Wise HM, Hermida MA, Leslie NR (2017) Prostate cancer, PI3K, PTEN and prognosis. Clin Sci (Lond) 131(3):197-210

237. Zhu W, Shao Y, Yang M et al (2016) Asparaginyl endopeptidase promotes proliferation and invasiveness of prostate cancer cells via PI3K/AKT signaling pathway. Gene 594(2):176-182 
238. Wu X, Xiao Y, Yan W et al (2019) The human oncogene SCL/ TAL1 interrupting locus (STIL) promotes tumor growth through MAPK/ERK, PI3K/Akt and AMPK pathways in prostate cancer. Gene 686:220-227

239. Quan Y, Wang N, Chen Q et al (2015) SIRT3 inhibits prostate cancer by destabilizing oncoprotein c-MYC through regulation of the PI3K/Akt pathway. Oncotarget 6(28):26494-26507

240. Henderson V, Smith B, Burton LJ et al (2015) Snail promotes cell migration through PI3K/AKT-dependent Rac1 activation as well as PI3K/AKT-independent pathways during prostate cancer progression. Cell Adh Migr 9(4):255-264

241. Offermann A, Vlasic I, Syring I et al (2017) MED15 overexpression in prostate cancer arises during androgen deprivation therapy via PI3K/mTOR signaling. Oncotarget 8(5):7964-7976

242. Zhou Y, Gu P, Li J et al (2017) Suppression of STIM1 inhibits the migration and invasion of human prostate cancer cells and is associated with PI3K/Akt signaling inactivation. Oncol Rep 38(5):2629-2636

243. Wei A, Fan B, Zhao Y et al (2016) ST6Gal-I overexpression facilitates prostate cancer progression via the PI3K/Akt/GSK-3beta/ beta-catenin signaling pathway. Oncotarget 7(40):65374-65388

244. Talesa VN, Ferri I, Bellezza G et al (2017) Glyoxalase 2 Is involved in human prostate cancer progression as part of a mechanism driven By PTEN/PI3K/AKT/mTOR signaling with involvement of PKM2 and ERalpha. Prostate 77(2):196-210

245. Han G, Zhang X, Liu P et al (2018) Knockdown of anti-silencing function $1 \mathrm{~B}$ histone chaperone induces cell apoptosis via repressing PI3K/Akt pathway in prostate cancer. Int $\mathrm{J}$ Oncol 53(5):2056-2066

246. Liang F, Yue J, Wang J et al (2015) GPCR48/LGR4 promotes tumorigenesis of prostate cancer via PI3K/Akt signaling pathway. Med Oncol 32(3):49

247. Chen C, Cai Q, He W et al (2017) AP4 modulated by the PI3K/ AKT pathway promotes prostate cancer proliferation and metastasis of prostate cancer via upregulating L-plastin. Cell Death Dis 8(10): 3060

248. Shao G, Liu Y, Ma T et al (2018) GCN5 inhibition prevents IL-6-induced prostate cancer metastases through PI3K/PTEN/ Akt signaling by inactivating Egr-1. Biosci Rep. https://doi. org/10.1042/BSR20180816

249. Tan M, Xu J, Siddiqui J et al (2016) Depletion of SAG/RBX2 E3 ubiquitin ligase suppresses prostate tumorigenesis via inactivation of the PI3K/AKT/mTOR axis. Mol Cancer 15(1):81

250. Chang YL, Zhou PJ, Wei L et al (2015) MicroRNA-7 inhibits the stemness of prostate cancer stem-like cells and tumorigenesis by repressing KLF4/PI3K/Akt/p21 pathway. Oncotarget 6(27):24017-24031

251. Yang J, Song Q, Cai Y et al (2015) RLIP76-dependent suppression of $\mathrm{PI} 3 \mathrm{~K} / \mathrm{AKT} / \mathrm{Bcl}-2$ pathway by miR-101 induces apoptosis in prostate cancer. Biochem Biophys Res Commun 463(4):900-906

252. Xu S, Ge J, Zhang Z et al (2017) MiR-129 inhibits cell proliferation and metastasis by targeting ETS1 via PI3K/AKT/mTOR pathway in prostate cancer. Biomed Pharmacother 96:634-641

253. Tang Y, Pan J, Huang S et al (2018) Downregulation of miR133a-3p promotes prostate cancer bone metastasis via activating PI3K/AKT signaling. J Exp Clin Cancer Res 37(1):160

254. Wang Y, Shao N, Mao X et al (2016) MiR-4638-5p inhibits castration resistance of prostate cancer through repressing Kidins 220 expression and PI3K/AKT pathway activity. Oncotarget 7(30):47444-47464

255. Wang YC, He WY, Dong $\mathrm{CH}$ et al (2019) lncRNA HCG11 regulates cell progression by targeting miR-543 and regulating AKT/mTOR pathway in prostate cancer. Cell Biol Int. https:// doi.org/10.1002/cbin.11194
256. Xu S, Yi XM, Tang CP et al (2016) Long non-coding RNA ATB promotes growth and epithelial-mesenchymal transition and predicts poor prognosis in human prostate carcinoma. Oncol Rep 36(1):10-22

257. Shen G, Jiang M, Pu J (2018) Dual inhibition of BRD4 and PI3K by SF2523 suppresses human prostate cancer cell growth in vitro and in vivo. Biochem Biophys Res Commun 495(1):567-573

258. Damayanti NP, Budka JA, Khella HWZ et al (2018) Therapeutic targeting of TFE3/IRS-1/PI3K/mTOR axis in translocation renal cell carcinoma. Clin Cancer Res 24(23):5977-5989

259. Lin $\mathrm{Y}$, Yang Z, Xu A et al (2015) PIK3R1 negatively regulates the epithelial-mesenchymal transition and stem-like phenotype of renal cancer cells through the AKT/GSK3beta/CTNNB1 signaling pathway. Sci Rep 5:8997

260. Lin A, Piao HL, Zhuang L et al (2014) FoxO transcription factors promote AKT Ser473 phosphorylation and renal tumor growth in response to pharmacologic inhibition of the PI3K-AKT pathway. Cancer Res 74(6):1682-1693

261. Huang B, Fu SJ, Fan WZ et al (2016) PKCepsilon inhibits isolation and stemness of side population cells via the suppression of ABCB1 transporter and PI3K/Akt, MAPK/ERK signaling in renal cell carcinoma cell line 769P. Cancer Lett 376(1):148-154

262. Zhao Z, Liu H, Hou J et al (2017) Tumor protein D52 (TPD52) inhibits growth and metastasis in renal cell carcinoma cells through the PI3K/Akt signaling pathway. Oncol Res 25(5):773-779

263. Liu S, Ma X, Ai Q et al (2013) NOTCH1 functions as an oncogene by regulating the PTEN/PI3K/AKT pathway in clear cell renal cell carcinoma. Urol Oncol 31(6):938-948

264. Zhang GW, Tian X, Li Y et al (2018) Down-regulation of ETS2 inhibits the invasion and metastasis of renal cell carcinoma cells by inducing EMT via the PI3K/Akt signaling pathway. Biomed Pharmacother 104:119-126

265. Liu GL, Yang HJ, Liu B et al (2017) Effects of microRNA-19b on the proliferation, apoptosis, and migration of wilms' tumor cells via the PTEN/PI3K/AKT signaling pathway. J Cell Biochem 118(10):3424-3434

266. Lian JH, Wang WH, Wang JQ et al (2013) MicroRNA-122 promotes proliferation, invasion and migration of renal cell carcinoma cells through the PI3K/Akt signaling pathway. Asian Pac J Cancer Prev 14(9):5017-5021

267. Fu JH, Yang S, Nan CJ et al (2018) MiR-182 affects renal cancer cell proliferation, apoptosis, and invasion by regulating PI3K/ AKT/mTOR signaling pathway. Eur Rev Med Pharmacol Sci 22(2):351-357

268. Pan Y, Hu J, Ma J et al (2018) MiR-193a-3p and miR-224 mediate renal cell carcinoma progression by targeting alpha-2,3-sialyltransferase IV and the phosphatidylinositol 3 kinase/Akt pathway. Mol Carcinog 57(8):1067-1077

269. Sun P, Wang L, Lu Y et al (2016) MicroRNA-195 targets VEGFR2 and has a tumor suppressive role in ACHN cells via PI3K/Akt and Raf/MEK/ERK signaling pathways. Int J Oncol 49(3):1155-1163

270. Li Z, Ma Z, Xu X (2019) Long noncoding RNA MALAT1 correlates with cell viability and mobility by targeting miR223p in renal cell carcinoma via the PI3K/Akt pathway. Oncol Rep 41(2):1113-1121

271. Liu G, Zhao X, Zhou J et al (2018) LncRNA TP73-AS1 promotes cell proliferation and inhibits cell apoptosis in clear cell renal cell carcinoma through repressing KISS1 expression and inactivation of PI3K/Akt/mTOR signaling pathway. Cell Physiol Biochem 48(1):371-384

272. Su Y, Lu J, Chen X et al (2019) Long non-coding RNA HOTTIP affects renal cell carcinoma progression by regulating autophagy via the PI3K/Akt/Atg13 signaling pathway. J Cancer Res Clin Oncol 145(3):573-588 
273. Lopez-Knowles E, Hernandez S, Malats N et al (2006) PIK3CA mutations are an early genetic alteration associated with FGFR3 mutations in superficial papillary bladder tumors. Cancer Res 66(15):7401-7404

274. Qian CN, Furge KA, Knol J et al (2009) Activation of the PI3K/ AKT pathway induces urothelial carcinoma of the renal pelvis: identification in human tumors and confirmation in animal models. Cancer Res 69(21):8256-8264

275. Lv S, Wang W, Wang $\mathrm{H}$ et al (2019) PPARgamma activation serves as therapeutic strategy against bladder cancer via inhibiting PI3K-Akt signaling pathway. BMC Cancer 19(1):204

276. Lu JJ, Su YW, Wang CJ et al (2019) Semaphorin 4D promotes the proliferation and metastasis of bladder cancer by activating the PI3K/AKT pathway. Tumori 105(3):231-242

277. Gong Y, Qiu W, Ning X et al (2015) CCDC34 is up-regulated in bladder cancer and regulates bladder cancer cell proliferation, apoptosis and migration. Oncotarget 6(28):25856-25867

278. Fan Y, Song X, Du H et al (2014) Down-regulation of miR-29c in human bladder cancer and the inhibition of proliferation in T24 cell via PI3K-AKT pathway. Med Oncol 31(7):65

279. Noguchi S, Yasui Y, Iwasaki J et al (2013) Replacement treatment with microRNA-143 and -145 induces synergistic inhibition of the growth of human bladder cancer cells by regulating PI3K/Akt and MAPK signaling pathways. Cancer Lett 328(2):353-361

280. Li Y, Shan Z, Liu C et al (2017) MicroRNA-294 promotes cellular proliferation and motility through the PI3K/AKT and JAK/ STAT pathways by upregulation of NRAS in bladder cancer. Biochemistry (Mosc) 82(4):474-482

281. Zhai X, Xu W (2018) Long noncoding RNA atb promotes proliferation, migration, and invasion in bladder cancer by suppressing microRNA-126. Oncol Res 26(7):1063-1072

282. Li Z, Hong S, Liu Z (2018) LncRNA LINC00641 predicts prognosis and inhibits bladder cancer progression through miR197-3p/KLF10/PTEN/PI3K/AKT cascade. Biochem Biophys Res Commun 503(3):1825-1829

283. Wang J, Ma W, Liu Y (2017) Long non-coding RNA HULC promotes bladder cancer cells proliferation but inhibits apoptosis via regulation of ZIC2 and PI3K/AKT signaling pathway. Cancer Biomark 20(4):425-434

284. Lv XY, Ma L, Chen JF et al (2018) Knockdown of DUXAP10 inhibits proliferation and promotes apoptosis in bladder cancer cells via PI3K/Akt/mTOR signaling pathway. Int J Oncol 52(1):288-294

285. Yang C, Li X, Wang Y et al (2012) Long non-coding RNA UCA1 regulated cell cycle distribution via CREB through PI3-K dependent pathway in bladder carcinoma cells. Gene 496(1):8-16

286. Hacioglu BM, Kodaz H, Erdogan B et al (2017) K-RAS and $\mathrm{N}$-RAS mutations in testicular germ cell tumors. Bosn J Basic Med Sci 17(2):159-163

287. Feldman DR, Iyer G, Van Alstine L et al (2014) Presence of somatic mutations within PIK3CA, AKT, RAS, and FGFR3 but not BRAF in cisplatin-resistant germ cell tumors. Clin Cancer Res 20(14):3712-3720

288. Xu H, Feng Y, Jia Z et al (2017) AXIN1 protects against testicular germ cell tumors via the PI3K/AKT/mTOR signaling pathway. Oncol Lett 14(1):981-986

289. Gan Y, Wang Y, Tan Z et al (2016) TDRG1 regulates chemosensitivity of seminoma TCam-2 cells to cisplatin via PI3K/Akt/ mTOR signaling pathway and mitochondria-mediated apoptotic pathway. Cancer Biol Ther 17(7):741-750

290. Wei J, Gan Y, Peng D et al (2018) Long non-coding RNA H19 promotes TDRG1 expression and cisplatin resistance by sequestering miRNA-106b-5p in seminoma. Cancer Med $7(12): 6247-6257$
291. Faiman B, Faiman M (2017) Living with hematologic cancer: recommendations, solutions. Cleve Clin J Med 84(7):528-534

292. Rajkumar SV (2016) Multiple myeloma: 2016 update on diagnosis, risk-stratification, and management. Am J Hematol 91(7):719-734

293. Ansell SM (2015) Hodgkin lymphoma: diagnosis and treatment. Mayo Clin Proc 90(11):1574-1583

294. Matsuki E, Younes A (2015) Lymphomagenesis in Hodgkin lymphoma. Semin Cancer Biol 34:14-21

295. Aravinth SP, Rajendran S, Li Y et al (2019) Epstein-Barr virusencoded LMP1 induces ectopic CD137 expression on Hodgkin and Reed-Sternberg cells via the PI3K-AKT-mTOR pathway. Leuk Lymphoma 60(11):2697-2704

296. Desch AK, Hartung K, Botzen A et al (2020) Genotyping circulating tumor DNA of pediatric Hodgkin lymphoma. Leukemia 34(1):151-166

297. Zhu F, Guo H, Bates PD et al (2019) PRMT5 is upregulated by B-cell receptor signaling and forms a positive-feedback loop with PI3K/AKT in lymphoma cells. Leukemia 33(12):2898-2911

298. Dutton A, Reynolds GM, Dawson CW et al (2005) Constitutive activation of phosphatidyl-inositide 3 kinase contributes to the survival of Hodgkin's lymphoma cells through a mechanism involving Akt kinase and mTOR. J Pathol 205(4):498-506

299. Kuppers R, Engert A, Hansmann ML (2012) Hodgkin lymphoma. J Clin Invest 122(10):3439-3447

300. Georgakis GV, Li Y, Rassidakis GZ et al (2006) Inhibition of the phosphatidylinositol-3 kinase/Akt promotes G1 cell cycle arrest and apoptosis in Hodgkin lymphoma. Br J Haematol 132(4):503-511

301. Locatelli SL, Careddu G, Serio S et al (2019) Targeting cancer cells and tumor microenvironment in preclinical and clinical models of Hodgkin lymphoma using the dual PI3Kdelta/ gamma inhibitor RP6530. Clin Cancer Res 25(3):1098-1112

302. Locatelli SL, Careddu G, Inghirami G et al (2016) The novel PI3K-delta inhibitor TGR-1202 enhances Brentuximab Vedotin-induced Hodgkin lymphoma cell death via mitotic arrest. Leukemia 30(12):2402-2405

303. Swerdlow SH, Campo E, Pileri SA et al (2016) The 2016 revision of the World Health Organization classification of lymphoid neoplasms. Blood 127(20):2375-2390

304. Armitage JO, Gascoyne RD, Lunning MA et al (2017) NonHodgkin lymphoma. Lancet 390(10091):298-310

305. Crisci S, Di Francia R, Mele S et al (2019) Overview of targeted drugs for mature B-cell non-hodgkin lymphomas. Front Oncol 9:443

306. Sukswai N, Lyapichev K, Khoury JD et al (2020) Diffuse large B-cell lymphoma variants: an update. Pathology 52(1):53-67

307. Sorigue M, Sancho JM (2019) Recent landmark studies in follicular lymphoma. Blood Rev 35:68-80

308. Pfeifer M, Grau M, Lenze D et al (2013) PTEN loss defines a PI3K/AKT pathway-dependent germinal center subtype of diffuse large B-cell lymphoma. Proc Natl Acad Sci USA 110(30):12420-12425

309. Pasqualucci L, Khiabanian H, Fangazio M et al (2014) Genetics of follicular lymphoma transformation. Cell Rep 6(1):130-140

310. Freedman A (2018) Follicular lymphoma: 2018 update on diagnosis and management. Am J Hematol 93(2):296-305

311. Devan J, Janikova A, Mraz M (2018) New concepts in follicular lymphoma biology: from BCL2 to epigenetic regulators and non-coding RNAs. Semin Oncol 45(5-6):291-302

312. Pongas G, Cheson BD (2016) PI3K signaling pathway in normal B cells and indolent B-cell malignancies. Semin Oncol 43(6):647-654

313. Clayton E, Bardi G, Bell SE et al (2002) A crucial role for the p110delta subunit of phosphatidylinositol 3-kinase in B cell development and activation. J Exp Med 196(6):753-763 
314. Okkenhaug K, Bilancio A, Farjot G et al (2002) Impaired B and $\mathrm{T}$ cell antigen receptor signaling in p110delta PI 3-kinase mutant mice. Science 297(5583):1031-1034

315. Gopal AK, Kahl BS, de Vos S et al (2014) PI3Kdelta inhibition by idelalisib in patients with relapsed indolent lymphoma. $\mathrm{N}$ Engl J Med 370(11):1008-1018

316. Feng Y, Cu X, Xin M (2019) PI3Kdelta inhibitors for the treatment of cancer: a patent review (2015-present). Expert Opin Ther Pat 29(12):925-941

317. Patnaik A, Appleman LJ, Tolcher AW et al (2016) First-inhuman phase I study of copanlisib (BAY 80-6946), an intravenous pan-class I phosphatidylinositol 3-kinase inhibitor, in patients with advanced solid tumors and non-Hodgkin's lymphomas. Ann Oncol 27(10):1928-1940

318. Markham A (2017) Copanlisib: first global approval. Drugs 77(18):2057-2062

319. Flinn IW, Miller CB, Ardeshna KM et al (2019) DYNAMO: a phase II study of duvelisib (IPI-145) in patients with refractory indolent non-hodgkin lymphoma. J Clin Oncol 37(11):912-922

320. Blair HA (2018) Duvelisib: first global approval. Drugs 78(17):1847-1853

321. Cui W, Ma M, Zheng S et al (2017) PIK3CA amplification and PTEN loss in diffused large B-cell lymphoma. Oncotarget 8(39):66237-66247

322. Chen L, Ouyang J, Wienand K et al (2019) CXCR4 upregulation is an indicator of sensitivity to B-cell receptor/PI3K blockade and a potential resistance mechanism in B-cell receptor-dependent diffuse large B-cell lymphomas. Haematologica 15:1-25. https ://doi.org/10.3324/haematol.2019.216218

323. Bojarczuk K, Wienand K, Ryan JA et al (2019) Targeted inhibition of PI3Kalpha/delta is synergistic with BCL-2 blockade in genetically defined subtypes of DLBCL. Blood 133(1):70-80

324. Kataoka K, Nagata Y, Kitanaka A et al (2015) Integrated molecular analysis of adult $\mathrm{T}$ cell leukemia/lymphoma. Nat Genet 47(11):1304-1315

325. Seffens A, Herrera A, Tegla C et al (2019) STAT3 dysregulation in mature T and NK cell lymphomas. Cancers (Basel) 11:25-30. https://doi.org/10.3390/cancers11111711

326. Matutes E (2018) The 2017 WHO update on mature T- and natural killer (NK) cell neoplasms. Int J Lab Hematol 40(Suppl 1):97-103

327. Fukuda R-I, Hayashi A, Utsunomiya A et al (2005) Alteration of phosphatidylinositol 3-kinase cascade in the multilobulated nuclear formation of adult T cell leukemia/lymphoma (ATLL). Proc Natl Acad Sci USA 102(42):15213-15218

328. Katsuya H, Cook LBM, Rowan AG et al (2018) Phosphatidylinositol 3-kinase-delta (PI3K-delta) is a potential therapeutic target in adult T-cell leukemia-lymphoma. Biomark Res 6:24

329. Ismail SI, Mahmoud IS, Msallam MM et al (2010) Hotspot mutations of PIK3CA and AKT1 genes are absent in multiple myeloma. Leuk Res 34(6):824-826

330. Hucthagowder V, Meyer R, Mullins C et al (2012) Resequencing analysis of the candidate tyrosine kinase and RAS pathway gene families in multiple myeloma. Cancer Genet 205(9):474-478

331. Frenquelli M, Caridi N, Antonini E et al (2020) The WNT receptor ROR2 drives the interaction of multiple myeloma cells with the microenvironment through AKT activation. Leukemia 34(1):257-270

332. Hofmann C, Stuhmer T, Schmiedl N et al (2014) PI3K-dependent multiple myeloma cell survival is mediated by the PIK3CA isoform. Br J Haematol 166(4):529-539

333. Ramakrishnan V, Kumar S (2018) PI3K/AKT/mTOR pathway in multiple myeloma: from basic biology to clinical promise. Leuk Lymphoma 59(11):2524-2534

334. Mimura N, Hideshima T, Shimomura T et al (2014) Selective and potent Akt inhibition triggers anti-myeloma activities and enhances fatal endoplasmic reticulum stress induced by proteasome inhibition. Cancer Res 74(16):4458-4469

335. Aronson LI, Davenport EL, Mirabella F et al (2013) Understanding the interplay between the proteasome pathway and autophagy in response to dual $\mathrm{PI} 3 \mathrm{~K} / \mathrm{mTOR}$ inhibition in myeloma cells is essential for their effective clinical application. Leukemia 27(12):2397-2403

336. Richardson PG, Wolf J, Jakubowiak A et al (2011) Perifosine plus bortezomib and dexamethasone in patients with relapsed/ refractory multiple myeloma previously treated with bortezomib: results of a multicenter phase I/II trial. J Clin Oncol 29(32):4243-4249

337. Jakubowiak AJ, Richardson PG, Zimmerman T et al (2012) Perifosine plus lenalidomide and dexamethasone in relapsed and relapsed/refractory multiple myeloma: a Phase I Multiple Myeloma Research Consortium study. Br J Haematol 158(4):472-480

338. Tolcher AW, Patnaik A, Papadopoulos KP et al (2015) Phase I study of the MEK inhibitor trametinib in combination with the AKT inhibitor afuresertib in patients with solid tumors and multiple myeloma. Cancer Chemother Pharmacol 75(1):183-189

339. Spencer A, Yoon SS, Harrison SJ et al (2014) The novel AKT inhibitor afuresertib shows favorable safety, pharmacokinetics, and clinical activity in multiple myeloma. Blood 124(14):2190-2195

340. Tasian SK, Teachey DT, Rheingold SR (2014) Targeting the $\mathrm{PI} 3 \mathrm{~K} / \mathrm{mTOR}$ pathway in pediatric hematologic malignancies. Front Oncol 4:108

341. Valent P (2011) Targeting of leukemia-initiating cells to develop curative drug therapies: straightforward but nontrivial concept. Curr Cancer Drug Targets 11(1):56-71

342. Li J, Zhang J, Tang M et al (2016) Hematopoietic stem cell activity is regulated by pten phosphorylation through a nichedependent mechanism. Stem Cells 34(8):2130-2144

343. Wu Y, Zhu H, Wu H (2019) PTEN in regulating hematopoiesis and leukemogenesis. Cold Spring Harb Perspect Med. https:// doi.org/10.1101/cshperspect.a036244

344. Wu Y, Hu Y, Yu X et al (2019) TAL1 mediates imatinib-induced CML cell apoptosis via the PTEN/PI3K/AKT pathway. Biochem Biophys Res Commun 519(2):234-239

345. Roszak J, Smok-Pieniazek A, Stepnik M (2017) Transcriptomic analysis of the PI3K/Akt signaling pathway reveals the dual role of the c-Jun oncogene in cytotoxicity and the development of resistance in HL-60 leukemia cells in response to arsenic trioxide. Adv Clin Exp Med 26(9):1335-1342

346. Kosalai ST, Morsy MHA, Papakonstantinou N et al (2019) EZH2 upregulates the PI3K/AKT pathway through IGF1R and MYC in clinically aggressive chronic lymphocytic leukaemia. Epigenetics 14(11):1125-1140

347. Li L, Qi Y, Ma X et al (2018) TRIM22 knockdown suppresses chronic myeloid leukemia via inhibiting PI3K/Akt/mTOR signaling pathway. Cell Biol Int 42(9):1192-1199

348. Fuka G, Kantner HP, Grausenburger R et al (2012) Silencing of ETV6/RUNX1 abrogates PI3K/AKT/mTOR signaling and impairs reconstitution of leukemia in xenografts. Leukemia 26(5):927-933

349. Jiang MJ, Dai JJ, Gu DN et al (2017) MicroRNA-7 inhibits cell proliferation of chronic myeloid leukemia and sensitizes it to imatinib in vitro. Biochem Biophys Res Commun 494(1-2):372-378

350. Palacios F, Abreu C, Prieto D et al (2015) Activation of the PI3K/ AKT pathway by microRNA-22 results in CLL B-cell proliferation. Leukemia 29(1):115-125

351. Yuan T, Yang Y, Chen J et al (2017) Regulation of PI3K signaling in T-cell acute lymphoblastic leukemia: a novel PTEN/ Ikaros/miR-26b mechanism reveals a critical targetable role for PIK3CD. Leukemia 31(11):2355-2364 
352. Wan L, Tian Y, Zhang R et al (2018) MicroRNA-103 confers the resistance to long-treatment of adriamycin to human leukemia cells by regulation of COP1. J Cell Biochem 119(5):3843-3852

353. Zhang Y, Zeng C, Lu S et al (2016) Identification of miR-125b targets involved in acute promyelocytic leukemia cell proliferation. Biochem Biophys Res Commun 478(4):1758-1763

354. Raffel S, Trumpp A (2016) miR-126 drives quiescence and selfrenewal in leukemic stem cells. Cancer Cell 29(2):133-135

355. Zhang R, Tang P, Wang F et al (2019) Tumor suppressor miR139-5p targets Tspan 3 and regulates the progression of acute myeloid leukemia through the PI3K/Akt pathway. J Cell Biochem 120(3):4423-4432

356. Zhao L, Li Y, Song X et al (2016) Upregulation of miR-181c inhibits chemoresistance by targeting ST8SIA4 in chronic myelocytic leukemia. Oncotarget 7(37):60074-60086

357. Li Y, Gao L, Luo X et al (2013) Epigenetic silencing of microRNA-193a contributes to leukemogenesis in $t(8 ; 21)$ acute myeloid leukemia by activating the PTEN/PI3K signal pathway. Blood 121(3):499-509

358. Chen L, Jiang X, Chen $\mathrm{H}$ et al (2019) microRNA-628 inhibits the proliferation of acute myeloid leukemia cells by directly targeting IGF-1R. Onco Targets Ther 12:907-919

359. Zhao L, Shan Y, Liu B et al (2017) Functional screen analysis reveals miR-3142 as central regulator in chemoresistance and proliferation through activation of the PTEN-AKT pathway in CML. Cell Death Dis 8(5):e2830

360. Lu Y, Li Y, Chai X et al (2017) Long noncoding RNA HULC promotes cell proliferation by regulating PI3K/AKT signaling pathway in chronic myeloid leukemia. Gene 607:41-46

361. Sun MD, Zheng YQ, Wang LP et al (2018) Long noncoding RNA UCA1 promotes cell proliferation, migration and invasion of human leukemia cells via sponging miR-126. Eur Rev Med Pharmacol Sci 22(8):2233-2245

362. Yang Y, Dai W, Sun Y et al (2019) Long noncoding RNA linc00239 promotes malignant behaviors and chemoresistance against doxorubicin partially via activation of the PI3K/Akt/ mTOR pathway in acute myeloid leukaemia cells. Oncol Rep 41(4):2311-2320

363. Ma L, Kuai WX, Sun XZ et al (2018) Long noncoding RNA LINC00265 predicts the prognosis of acute myeloid leukemia patients and functions as a promoter by activating PI3K-AKT pathway. Eur Rev Med Pharmacol Sci 22(22):7867-7876

364. Bertacchini J, Heidari N, Mediani L et al (2015) Targeting PI3K/ AKT/mTOR network for treatment of leukemia. Cell Mol Life Sci 72(12):2337-2347

365. Brown JR (2016) The PI3K pathway: clinical inhibition in chronic lymphocytic leukemia. Semin Oncol 43(2):260-264

366. Kost SEF, Saleh A, Mejia EM et al (2019) Transcriptional modulation by idelalisib synergizes with bendamustine in chronic lymphocytic leukemia. Cancers (Basel) 11:10. https://doi. org/10.3390/cancers11101519

367. Bashash D, Delshad M, Safaroghli-Azar A et al (2017) Novel pan PI3K inhibitor-induced apoptosis in APL cells correlates with suppression of telomerase: an emerging mechanism of action of BKM120. Int J Biochem Cell Biol 91(Pt A):1-8

368. Shah K, Moharram SA, Kazi JU (2018) Acute leukemia cells resistant to $\mathrm{PI} 3 \mathrm{~K} / \mathrm{mTOR}$ inhibition display upregulation of P2RY14 expression. Clin Epigenetics 10:83

369. Perry JA, Kiezun A, Tonzi P et al (2014) Complementary genomic approaches highlight the PI3K/mTOR pathway as a common vulnerability in osteosarcoma. Proc Natl Acad Sci USA 111(51):E5564-5573

370. Gupte A, Baker EK, Wan SS et al (2015) Systematic screening identifies dual PI3K and mTOR inhibition as a conserved therapeutic vulnerability in osteosarcoma. Clin Cancer Res 21(14):3216-3229
371. Gobin B, Battaglia S, Lanel R et al (2014) NVP-BEZ235, a dual $\mathrm{PI} 3 \mathrm{~K} / \mathrm{mTOR}$ inhibitor, inhibits osteosarcoma cell proliferation and tumor development in vivo with an improved survival rate. Cancer Lett 344(2):291-298

372. Moore JBT, Loeb DM, Hong KU et al (2015) Epigenetic reprogramming and re-differentiation of a Ewing sarcoma cell line. Front Cell Dev Biol 3:15

373. Ren C, Ren T, Yang K et al (2016) Inhibition of SOX2 induces cell apoptosis and G1/S arrest in Ewing's sarcoma through the PI3K/Akt pathway. J Exp Clin Cancer Res 35:44

374. Zhao X, Fang Y, Wang X et al (2020) Knockdown of Ski decreases osteosarcoma cell proliferation and migration by suppressing the PI3K/Akt signaling pathway. Int J Oncol 56(1):206-218

375. Ye C, Yu X, Liu X et al (2018) miR-30d inhibits cell biological progression of Ewing's sarcoma by suppressing the MEK/ERK and PI3K/Akt pathways in vitro. Oncol Lett 15(4):4390-4396

376. Zhang S, Li D, Jiao GJ et al (2018) miR-185 suppresses progression of Ewing's sarcoma via inhibiting the PI3K/AKT and Wnt/ beta-catenin pathways. Onco Targets Ther 11:7967-7977

377. Passacantilli I, Frisone P, De Paola E et al (2017) hnRNPM guides an alternative splicing program in response to inhibition of the PI3K/AKT/mTOR pathway in Ewing sarcoma cells. Nucleic Acids Res 45(21):12270-12284

378. Schadendorf D, Fisher DE, Garbe C et al (2015) Melanoma Nat Rev Dis Primers 1:15003

379. Leonardi GC, Falzone L, Salemi R et al (2018) Cutaneous melanoma: from pathogenesis to therapy (review). Int J Oncol 52(4):1071-1080

380. Marsh Durban V, Deuker MM, Bosenberg MW et al (2013) Differential AKT dependency displayed by mouse models of BRAFV600E-initiated melanoma. J Clin Invest 123(12):5104-5118

381. Gibney GT, Smalley KS (2013) An unholy alliance: cooperation between BRAF and NF1 in melanoma development and BRAF inhibitor resistance. Cancer Discov 3(3):260-263

382. Nissan MH, Pratilas CA, Jones AM et al (2014) Loss of NF1 in cutaneous melanoma is associated with RAS activation and MEK dependence. Cancer Res 74(8):2340-2350

383. Deuker MM, Marsh Durban V, Phillips WA et al (2015) PI3'kinase inhibition forestalls the onset of MEK1/2 inhibitor resistance in BRAF-mutated melanoma. Cancer Discov 5(2):143-153

384. Fernandez NB, Lorenzo D, Picco ME et al (2016) ROR1 contributes to melanoma cell growth and migration by regulating $\mathrm{N}$-cadherin expression via the PI3K/Akt pathway. Mol Carcinog 55(11):1772-1785

385. Wang J, Li L, Liu S et al (2016) FOXC1 promotes melanoma by activating MST1R/PI3K/AKT. Oncotarget 7(51):84375-84387

386. Oliveira CS, de Bock CE, Molloy TJ et al (2014) Macrophage migration inhibitory factor engages PI3K/Akt signalling and is a prognostic factor in metastatic melanoma. BMC Cancer 14:630

387. Schlegel NC, von Planta A, Widmer DS et al (2015) PI3K signalling is required for a TGFbeta-induced epithelial-mesenchymallike transition (EMT-like) in human melanoma cells. Exp Dermatol 24(1):22-28

388. Gao H, Liu R, Sun X (2019) STAT3-induced upregulation of lncRNA SNHG17 predicts a poor prognosis of melanoma and promotes cell proliferation and metastasis through regulating PI3K-AKT pathway. Eur Rev Med Pharmacol Sci 23(18):8000-8010

389. Yang Y, Zhang Z, Wu Z et al (2019) Downregulation of the expression of the lncRNA MIAT inhibits melanoma migration and invasion through the PI3K/AKT signaling pathway. Cancer Biomark 24(2):203-211

390. Chen X, Dong H, Liu S et al (2017) Long noncoding RNA MHENCR promotes melanoma progression via regulating 
miR-425/489-mediated PI3K-Akt pathway. Am J Transl Res 9(1):90-102

391. Wu J, Zhou MY, Yu XP et al (2019) Long noncoding RNA OR3A4 promotes the migration and invasion of melanoma through the PI3K/AKT signaling pathway. Eur Rev Med Pharmacol Sci 23(16):6991-6996

392. Liao Z, Zhao J, Yang Y (2018) Downregulation of lncRNA H19 inhibits the migration and invasion of melanoma cells by inactivating the NFkappaB and PI3K/Akt signaling pathways. Mol Med Rep 17(5):7313-7318

393. Dzneladze I, He R, Woolley JF et al (2015) INPP4B overexpression is associated with poor clinical outcome and therapy resistance in acute myeloid leukemia. Leukemia 29(7):1485-1495

394. Rijal S, Fleming S, Cummings N et al (2015) Inositol polyphosphate 4-phosphatase II (INPP4B) is associated with chemoresistance and poor outcome in AML. Blood 125(18):2815-2824

395. Gasser JA, Inuzuka H, Lau AW et al (2014) SGK3 mediates INPP4B-dependent PI3K signaling in breast cancer. Mol Cell 56(4):595-607
396. Fruman DA, Rommel C (2011) PI3Kdelta inhibitors in cancer: rationale and serendipity merge in the clinic. Cancer Discov 1(7):562-572

397. Macias-Perez IM, Flinn IW (2013) GS-1101: a delta-specific PI3K inhibitor in chronic lymphocytic leukemia. Curr Hematol Malig Rep 8(1):22-27

398. Chandarlapaty S, Sawai A, Scaltriti M et al (2011) AKT inhibition relieves feedback suppression of receptor tyrosine kinase expression and activity. Cancer Cell 19(1):58-71

399. Ghosh JC, Siegelin MD, Vaira V et al (2015) Adaptive mitochondrial reprogramming and resistance to PI3K therapy. J Natl Cancer Inst 107:3. https://doi.org/10.1093/jnci/dju502

400. Caino MC, Ghosh JC, Chae YC et al (2015) PI3K therapy reprograms mitochondrial trafficking to fuel tumor cell invasion. Proc Natl Acad Sci U S A 112(28):8638-8643

Publisher's Note Springer Nature remains neutral with regard to jurisdictional claims in published maps and institutional affiliations. 